\title{
The Biases of Risk Tradeoff Analysis: Towards Parity in Environmental and Health-and-Safety Regulation
}

\author{
Samuel J. Rascoff \\ Richard L. Revesz ††
}

Risk tradeoff analysis is in the process of transforming the practice of regulation. Its core idea is simple and intuitively appealing: Regulations undertaken to minimize or eliminate certain health risks often have the perverse effect of promoting other risks. A serious analysis of the impact of a regulation should pay attention not only to its primary effects in reducing the so-called target risk, but also to the secondary effects of the regulation in bringing about "ancillary risks" In this way, risk tradeoff analysis promises a more rational technique for the evaluation of regulation.

Risk tradeoff analysis, however, focuses exclusively on the negative secondary effects of risk regulation, but systematically ignores the phenomenon of "ancillary benefits" the reductions in risk that take place in addition to-and as a direct or indirect result of-reductions in the target risk The resulting conclusions are therefore consistently biased against regulation. This methodological bias is, in turn, reinforced by an institutional bias that emerges when risk tradeoff analysis is applied in the administrative state. Agency inattention to ancillary effects gives rise to iterative processes of administrative oversight and judicial review that privilege the opponents of regulation.

This Article sheds light on these biases and proposes a solution: ancillary benefit analysis. This technique would direct the attention of administrative decisionmakers to the positive byproducts of regulation designed to promote health, safety, and the environment. At a time when risk tradeoff analysis enjoys ever-growing support in the courts and the academy, this Article proposes an approach through which to counteract its one-sidedness.

\section{INTRODUCTION}

"Risk-risk analysis," also referred to as "risk tradeoff analysis" and "health-health analysis," is transforming the practice of regula-

$\dagger$ Law Clerk to Judge Pierre N. Leval of the United States Court of Appeals for the Second Circuit; Postdoctoral Fellow, Center on Environmental and Land Use Law, New York University School of Law, Fall 2001. A.B. 1996, Harvard University; B.A. 1998, Oxford University; J.D. 2001, Yale Law School.

t† Dean and Lawrence King Professor of Law, New York University School of Law. The Filomen D'Agostino and Max E. Greenberg Research Fund at the New York University School of Law provided financial assistance. We are grateful for the comments of Noah Feldman, Louis Kaplow, Lewis Kornhauser, Howell Jackson, Richard Stewart, W. Kip Viscusi, Jonathan Wiener, and the participants in the Law and Economics Workshop at Harvard Law School and in the Advanced Environmental Law Seminar at New York University School of Law. Itai Greenberg and Kelsey Jack were excellent research assistants.

1 The concept of "risk-risk" was first explained in Lester B. Lave, The Strategy of Social 
tion. In a path-breaking concurrence in Whitman $v$ American Trucking Associations, Inc, last term's most-watched administrative law case, Justice Stephen Breyer explicitly embraced the methodology, to which we shall refer generally as risk tradeoff analysis. ${ }^{6}$ A number of prominent federal judges, principally Judge Stephen Williams ${ }^{7}$ of the D.C. Circuit (who, like Justice Breyer, is a distinguished scholar in the field), and administrative law scholars, such as Professors Cass Sunstein $^{8}$ and W. Kip Viscusi, have also advocated the broad application

Regulation: Decision Frameworks for Policy 15 (Brookings 1981).

2 The most comprehensive work to date on risk tradeoffs is John D. Graham and Jonathan Baert Wiener, eds, Risk versus Risk: Tradeoffs in Protecting Health and the Environment (Harvard 1995). Graham and Wiener coined the term "risk tradeoff analysis." See John D. Graham and Jonathan Baert Wiener, Confronting Risk Tradeoffs, in Graham and Wiener, eds, Risk versus Risk 1, 4.

3 The secondary literature on health-health tradeoffs, which significantly overlaps with the secondary literature on health-wealth interactions, is extensive. For an important investigation of the implications of health-health tradeoffs for law, see, for example, Cass R. Sunstein, HealthHealth Tradeoffs, 63 U Chi L Rev 1533 (1996) (proposing a framework for how regulatory agencies should approach health-health tradeoffs). See also Ralph L. Keeney, Mortality Risks Induced by Economic Expenditures, 10 Risk Anal 147 (1990) (presenting a framework for investigating indirect health risks due to expenditures); Aaron Wildavsky, Searching for Safety (Social Philosophy and Policy Center 1988) (arguing that health, safety, and risk should be viewed as inevitably mixed); Aaron Wildavsky, Richer Is Safer, 60 Pub Int 23 (1980) (observing connections between greater wealth and increased health).

4531 US 457, 490 (2001) (Breyer concurring in part and concurring in the judgment).

5 In addition to his judicial writing, Justice Breyer has contributed an important monograph in the area of risk regulation. See Stephen Breyer, Breaking the Vicious Circle: Toward Effective Risk Regulation (Harvard 1993) (calling for greater rationality and coordination in federal health-and-safety regulation).

6 The precise meaning of these concepts is contested. For the purposes of this Article, we will employ the concept of risk tradeoff analysis to encompass a broad range of phenomena. This approach is consistent with our observations that these methodological approaches bear an important "family resemblance" to one another, and differ primarily in the relative directness of the ancillary effects of the regulation. See text accompanying notes 32-37.

7 Judge Williams has employed risk tradeoff analysis both in his opinions, see text accompanying notes 60-66, 71-73, and 96-97, and in his scholarly articles, see, for example, Stephen F. Williams, The Era of "Risk-Risk" and the Problem of Keeping the APA Up to Date, 63 U Chi L Rev 1375 (1996) (discussing approaches to risk-risk and health-health analysis); Stephen F. Williams, Second Best: The Soft Underbelly of Deterrence Theory in Tort, 106 Harv L Rev 932 (1993) (applying risk-risk analysis to tort law).

8 See, for example, Cass R. Sunstein, Free Markets and Social Justice 298-317 (Oxford 1997) (proposing a framework for health-health tradeoffs); Sunstein, 63 U Chi L Rev at 1561-69 (cited in note 3 ) (exploring the application of risk tradeoff analysis in the courts and throughout the administrative state); Cass R. Sunstein, Legislative Foreword: Congress, Constitutional Moments, and the Cost-Benefit State, 48 Stan L Rev 247, 307 (1996) (examining the 104th Congress and the Contract with America as signals of the evolution of a cost-benefit state).

9 See, for example, W. Kip Viscusi, Regulating the Regulators, 63 U Chi L Rev 1423, 143755 (1996) (exploring various techniques for assessing risk-risk analysis, among other regulatory techniques); W. Kip Viscusi, Fatal Tradeoffs: Public and Private Responsibilities for Risk 149-292 (Oxford 1992) (addressing fundamental principles of risk regulation). For a general discussion of the relationship between risk regulation and health expenditures and its impact on standard cost-benefit and risk reduction tests, see W. Kip Viscusi, Mortality Effects of Regulatory Costs and Policy Evaluation Criteria, 25 RAND J Econ 94 (1994). 
of risk tradeoff analysis. Congress has on numerous occasions considered the possibility of requiring agencies to undertake some type of risk tradeoff analysis before promulgating regulations. ${ }^{10}$ And John $D$. Graham, perhaps the name most closely identified with the emergence of risk tradeoff analysis, "was recently tapped by President Bush to head the Office of Information and Regulatory Affairs ("OIRA") in the Office of Management and Budget ("OMB"), the institution responsible for overseeing the regulatory efforts of administrative agencies."

The guiding idea behind risk tradeoff analysis is simple and intuitively appealing: Regulations undertaken to minimize or eliminate certain health risks often have the perverse effect of promoting other risks. ${ }^{13}$ A serious analysis of a regulation should therefore pay attention not only to the regulation's primary effects in reducing the socalled target risk ${ }^{14}$ but also to the secondary effects of the regulation in calling forth "countervailing" or "ancillary" risks. In this way, risk tradeoff analysis promises a more rational technique for the evaluation of regulation.

10 See, for example, HR 1022, $\$ 105(4)$, 104th Cong, 1st Sess (Feb 23, 1995), which on March 3, 1995 became part of HR 9, § 415(4), 104th Cong, 1st Sess (Jan 4, 1995) ("Each significant risk assessment or risk characterization document shall include a statement of any significant substitution risks to human health, where information on such risks has been provided to the agency."); S 343, \$ 636(2), 104th Cong, 1st Sess (Feb 2, 1995) ("When a covered agency provides a risk assessment or risk characterization for a proposed or final regulatory action, such assessment or characterization shall include a statement of any significant substitution risks, when information on such risks has been made available to the agency."); $\mathrm{S} 981, \S 624(\mathrm{~h}), 105$ th Cong, $2 \mathrm{~d}$ Sess (June 27,1997) ("When scientifically appropriate information on significant substitution risks to health, safety, or the environment is reasonably available to the agency, the agency shall describe such risks in the risk assessment."); S 746, § 621(11), 106th Cong, 1st Sess (Mar 25,1999) (defining the term "substitution risk"); HR 3311, § 621 (7)(C)(ii), 106th Cong, 1st Sess (Nov 10, 1999) (requiring that any health, safety, or environmental regulation be accompanied by a risk assessment of, inter alia, "an evaluation of any substitution risk relating to the proposed rule").

11 See generally Graham and Wiener, eds, Risk versus Risk (cited in note 2) (presenting the most sustained account of risk tradeoffs to date).

12 Graham was confirmed by the Senate on July 19,2001 , by a vote of $61-37$. See Washington in Brief, Wash Post A4 (July 20, 2001).

13 See text accompanying notes $42-49$ and $67-78$ for some examples.

14 Graham and Wiener define "target risk" as "the risk that is the primary focus of riskreduction efforts." Graham and Wiener, Confronting Risk Tradeoffs at 23 (cited in note 2). Sunstein speaks of the "regulated risk." Sunstein, 63 U Chi L Rev at 1539 (cited in note 3).

15 Graham and Wiener define a "countervailing risk" (which we use interchangeably with "ancillary risk") as "the chance of an adverse outcome that results from an activity whose ostensible purpose is to reduce the target risk." Graham and Wiener, Confronting Risk Tradeoffs at 23 (cited in note 2).

16 Risk tradeoffs are essentially a case of a broader phenomenon of actions that bring about unanticipated or undesirable side effects. In a meaningful sense, the economic analysis of externalities represents an attempt to come to terms with such a phenomenon. See, for example, Guido Calabresi and A. Douglas Melamed, Property Rules, Liability Rules, and Inalienability: One View of the Cathedral, 85 Harv L Rev 1089, 1111-12 (1972) (noting some legal implications of externalities). See also Edward Tenner, Why Things Bite Back:Technology and the Revenge of 
In practice, however, risk tradeoff analysis does not deliver on that promise. At the core of risk tradeoff analysis lies an important methodological flaw: inattention to ancillary benefits. Risk tradeoff analysis focuses on and attempts to quantify only the negative-that is to say, the risk-promoting-secondary effects of risk regulation. Through the very definition of its own methodological enterprise, risk tradeoff analysis systematically ignores the phenomenon of "ancillary benefits," reductions in risk that take place in addition to-and as a direct or indirect result of-reductions in the target risk. The resulting legal and scholarly conclusions about the desirability of regulation therefore are consistently distorted.

Although they have not yet figured in academic debates about regulation or in regulatory practice, ancillary benefits have been observed across a broad range of contexts. A representative list reveals the widespread nature of the phenomenon. ${ }^{17}$ For example, a more stringent standard for carbon monoxide emissions in automobile exhaust not only achieved its target of reducing air pollution, but also had the ancillary benefit of significantly reducing loss of life attributable to carbon monoxide-related accidents and suicides. ${ }^{\text {is }}$ Policies targeting greenhouse gas reductions can be expected to have the ancillary benefit of reducing conventional air pollutants. ${ }^{19}$ Policies favoring wastewater management through constructed wetlands have ancillary benefits for public use and preservation of habitats. ${ }^{20}$

Medical interventions-most notably drug therapies-have been observed to have significant ancillary benefits. To take only a few examples, aspirin, first introduced as an analgesic and anti-pyretic, is now widely used to reduce the risk of heart attack, ${ }^{2}$ and may help prevent against certain cancers. ${ }^{23}$ Minoxidil, approved by the FDA as

Unintended Consequences (Knopf 1996) (observing that technological innovation entails unwanted consequences).

17 We discuss these and other examples of ancillary benefits more fully in Part III.C. In Part III.B we argue that there is no convincing argument why ancillary benefits should be less prevalent than ancillary harms.

18 See M. Shelef, Unanticipated Benefits of Automotive Emission Control: Reduction in Fatalities by Motor Vehicle Exhaust Gas, 146/147 Sci Total Envir 93,93-94 (1994).

19 See generally Dallas Burtraw, et al, Ancillary Benefits of Reduced Air Pollution in the United States from Moderate Greenhouse Gas Mitigation Policies in the Electricity Sector, Discussion Paper No 01-61 (Resources for the Future 2001), available online at <http://www.rff.org/ disc_papers/PDF_files/0161.pdf (visited April 20, 2002).

20 See, Robert L. Knight, Wildlife Habitat and Public Use Benefits of Treatment Wetlands, 35 Water Sci \& Tech 35, 36-39 (1995).

21 We discuss these and other instances of the ancillary benefits of drug therapies in Part III.C.1.

22 See, for example, Prevention: Aspirin Underused to Prevent Heart Attacks, Strokes, Heart Disease Weekly 8, 9 (Feb 3, 2002) ("[A]spirin is a life-saving treatment that will provide major benefits to many thousands of people at high risk of heart attack or stroke.").

23 See, for example, Pasi Jänne and Robert J. Mayer, Chemoprevention of Colorectal Can- 
an antihypertensive, is now more frequently prescribed to treat hair loss. ${ }^{24}$ As this partial survey suggests, ancillary benefits are a real-if heretofore understudied-phenomenon.

The methodological bias born of inattention to ancillary benefits is in turn perpetuated and reinforced by institutional biases that emerge when risk tradeoff analysis is applied in the rulemaking process. "Tunnel vision" within agencies prevents them from considering ancillary effects altogether-both positive and negative. ${ }^{25}$ However, the processes that OIRA and the courts use to review agency action privilege consideration of ancillary harms over ancillary benefits. OIRA generally is perceived to have pursued an antiregulatory agenda ${ }^{26}$ ever since Executive Order 12291 empowered it to review regulation for compliance with cost-benefit principles. ${ }^{27}$ It is not surprising, therefore, that $\mathrm{OMB}$ oversight privileges the ancillary harms of regulation over ancillary benefits. ${ }^{23}$ In the courts, bias emerges from the complex interplay between various doctrines and incentive structures associated with judicial review of regulation. The cumulative effect of the biases that emerge from the review of agency action by OIRA and the courts is to place an unjustified obstacle in the way of socially beneficial regulations.

We propose a remedy for these methodological and institutional biases: ancillary benefit analysis. ${ }^{30}$ This technique corrects the meth-

cer, 342 New Eng J Med 1960, 1961 (2000) (noting that "it is likely that aspirin ... act[s] as [a] chemopreventive agent $\square$ at early stages of carcinogenesis").

24 See, for example, Vera H. Price, Treatment of Hair Loss, 341 New Eng J Med 964, 966 (1999).

25 See Breyer, Breaking the Vicious Circle at 11 (cited in note 5) (proposing that standard economic analysis, which fails to take externalities into account, leads to undesirable results when choosing between regulatory alternatives). See also Richard B. Stewart, $A$ New Generation of Environmental Regulation?, 29 Cap U L Rev 21, 153 (2001) (drawing attention to the problem of fragmentation in environmental regulation).

26 See, for example, Robert V. Percival, et al, Environmental Regulation: Law, Science, and Policy 694 (Little, Brown 1996) ("What does seem evident is that regulatory review was used exclusively to promote less stringent regulation rather than to increase the net benefits of regulation."); Erik D. Olson, The Quiet Shift of Power: Office of Management \& Budget Supervision of Environmental Protection Agency Rulemaking under Executive Order 12,291, 4 Va J Natural Resources L 1, 43 (1984) (citing former OIRA Deputy Administrator Jim Tozzi for the idea that OMB begins with a "rebuttable presumption against regulation").

27 Exec Order 12291, 3 CFR $\$ 127$ (1981). This executive order, which has been called the “'constitution' of OMB review," E. Donald Elliott, TQM-ing OMB: Or Why Regulatory Review under Executive Order 12,291 Works Poorly and What President Clinton Should Do about It, 57 L \& Contemp Probs 167, 169 (Spring 1994), required a Regulatory Impact Analysis of all rules with an annual economic impact of $\$ 100$ million or more. We discuss the OMB review process more fully in Part IV.B.

28 See text accompanying notes $318-20$.

29 See text accompanying note 62.

30 We propose ancillary benefit analysis as an antidote to the one-sidedness of risk tradeoff analysis. It is not intended as an alternative (but rather as a potential aid) to cost-benefit analysis, although, together with risk tradeoff analysis, it may occasionally function as such, as where cost- 
odological bias in risk tradeoff analysis by directing attention to the positive ancillary effects generated by environmental and health-andsafety regulation. Moreover, administrative agencies that invoke ancillary benefit analysis at the time of their initial decision can avoid the institutional biases otherwise introduced by OIRA and the courts. In turn, Congress, in considering future regulatory reform legislation, should require agencies to consider ancillary benefits alongside ancillary risks.

At a time when risk tradeoff analysis enjoys ever-growing support in the courts and the academy, we raise serious questions about its one-sidedness. By complementing-rather than displacing-risk tradeoff analysis, ancillary benefit analysis will help promote greater rationality in the administrative state.

The Article proceeds as follows. Part I presents a typology of risk tradeoffs, focusing on the kinds of tradeoffs that have been observed by academic commentators. It draws on a number of opinions by Judge Williams to illustrate how such tradeoffs have become cognizable in the judicial review of administrative action.

Part II underscores the striking ascendancy of risk tradeoff analysis both in the academy and in the regulatory state. It begins by outlining various academic proposals for its widespread implementation. Then it turns to an analysis of the current role of risk tradeoff analysis in Congress, the agencies, and OMB. In order to highlight the growing prominence of risk tradeoff analysis in the courts, Part II engages in a close reading of Justice Breyer's concurrence in American Trucking. ${ }^{3 .}$

Part III focuses on the inattention to ancillary benefits in the administrative state and among academic proponents of risk tradeoff analysis. It first offers a historical account of this methodological bias. Then it critically evaluates a defense, put forward by John D. Graham and Jonathan Baert Wiener on public choice grounds, of the inattention to ancillary benefits. Drawing on the typology of risk tradeoffs identified in Part I, it next provides examples of different types of ancillary benefits that have been observed. Finally, it raises serious methodological questions about health-health tradeoffs and lulling effects, two types of risk tradeoffs.

Part IV addresses the institutional biases in the application of risk tradeoff analysis that reinforce the methodological bias. As already indicated, these biases arise from the tunnel vision of administrative agencies coupled with the manner in which OMB performs a centralized review of regulations and the doctrines governing judicial review of administrative action. 
In Part V, we discuss how to address the antiregulatory effects of current administrative practice. We argue that the character of OMB review is unlikely to change and that courts cannot solve the problem as a result of the well-established doctrines governing judicial review. To the extent that Congress enacts comprehensive regulatory reform legislation in the future, it should treat risk tradeoffs and ancillary benefits in a parallel manner, not privileging the former over the latter. At present, however, the best answer lies with the agencies. We develop a case study to show how agencies might consider ancillary benefits in the rulemaking process.

The Conclusion places our call for ancillary benefit analysis within a broader conceptual framework. We underscore that a commitment to rationality requires parity in the treatment of risk tradeoffs and ancillary benefits.

\section{A TAXONOMY OF RISK TRADEOFFS}

We define four categories of risk tradeoffs: direct risk tradeoffs, substitution effects, lulling effects, and health-health tradeoffs. ${ }^{32}$ We provide prominent examples of each category from the academic literature and from Judge Williams's judicial opinions.

Our typology analyzes the various kinds of risk tradeoffs according to the relationship between the regulatory intervention and the ancillary risk. Does the ancillary risk come about directly as a result of the regulation, or is its emergence mediated by an intervening chain of events? $?^{33}$ In direct risk tradeoffs, the causal link is typically robust. By contrast, where risk tradeoffs are generated through substitution effects, lulling effects, or health-health tradeoffs, the connection between the regulatory intervention and the ancillary effect is somewhat more tenuous.

Distinguishing among various types of tradeoffs on the basis of the nexus between the regulation and the tradeoff to which it gives rise is useful for three reasons. ${ }^{34}$ First, it draws attention to an impor-

32 Sunstein provides a suggestive list of various types of tradeoffs but does not produce a typology. See Sunstein, $63 \mathrm{U}$ Chi L Rev at 1541-42 (cited in note 3).

33 Commentators have referred to "direct" and "indirect" risk-risk phenomena, although not precisely in the sense that we do. Lester Lave, for instance, distinguishes between direct and indirect effects not in terms of their causal link to a regulatory intervention, but in terms of the population affected. See Lave, Strategy of Social Regulation at 15-17 (cited in note 1).

34 Graham and Wiener provide a different typology, which focuses on two dimensions: the nature of the ancillary risk as compared with the target risk, and the population affected by the ancillary risk as compared with the target risk. They produce the following two-by-two matrix:

\begin{tabular}{|l|l|l|}
\hline & SAME TYPE & DIFFERENT TYPE \\
\hline SAME POPULATION & Risk Offset & Risk Substitution \\
\hline DIFFERENT POPULATION & Risk Transfer & Risk Transformation \\
\hline
\end{tabular}


tant methodological question about risk tradeoff analysis: How immediate a relationship must the ancillary effect bear to the regulatory intervention in order to be taken into account by risk tradeoff analysis? ? $^{35}$ Second, our taxonomy reveals the strong family resemblance shared by the various types of tradeoffs. In the face of some attempts to distinguish rigidly between direct and substitution risk tradeoffs on the one hand, and health-health tradeoffs on the other, we show their important analytic continuities. Finally, in spite of its growing importance, risk tradeoff analysis has been riddled by terminological confusion. ${ }^{37}$ Our typology suggests a coherent approach to analyzing related phenomena.

Graham and Wiener, Confronting Risk Tradeoffs at 19-22 (cited in note 2). They helpfully draw attention to two important dimensions of risk tradeoffs. First, by observing that the ancillary risk might differ in kind from the target risk (whether through what they call "substitution" or "transformation"), they help explain why government agencies, which suffer from tunnel vision and bureaucratic fragmentation, often fail to take ancillary effects into account. See id at 22-25. See also the discussion of fragmentation of decisionmaking into specialized "bounded oversight roles" in Jonathan Baert Wiener and John D. Graham, Resolving Risk Tradeoffs, in Graham and Wiener, eds, Risk versus Risk 226, 235-41 (cited in note 2), and the discussion of tunnel vision in Breyer, Breaking the Vicious Circle at 11-19 (cited in note 5). We discuss the problem of bureaucratic fragmentation in the text accompanying notes 295-316. Second, this typology throws light on the redistributive aspects of regulatory intervention by observing that the populations affected by the target and anciliary risks might be different. We critically examine "risk transfers" and "risk transformations" in the text accompanying notes 196-201.

35 "An important question about a possible methodology for estimating indirect risks is, where should one stop modeling?" Ralph L. Keeney and Detlof von Winterfeldt, Why Indirect Health Risks of Regulation Should Be Examined, 16 Interfaces 13, 25 (Nov/Dec 1986). Wiener thoughtfully considers what he refers to as the "optimal stopping problem." Jonathan Baert Wiener, Managing the Iatrogenic Risks of Risk Management, 9 Risk 39, 73-74 (1998).

36 Graham and Wiener, for instance, question the inclusion of health-health effects under the rubric of risk tradeoffs, since the health risks associated with the high cost of regulation "are not uniquely related to policies aimed at risk reduction." Graham and Wiener, Confronting Risk Tradeoffs at 20 (cited in note 2). They reason that all government spending, and not just spending on health-and-safety regulation, may reduce overall economic performance, and with it overall health. Similarly, Wiener compares direct risk tradeoffs to iatrogenesic disease and injury, while analogizing health-health tradeoffs to triage, where resources committed to one enterprise or cause are not available for another. See Wiener, 9 Risk at 51-53 (1998) (cited in note 35).

However, a form of the same critical argument can be applied to direct risk tradeoffs as well. Imagine the entire universe of decisions that bring about ancillary health risks. Some of those decisions will take the form of health-and-safety regulations, but many of them will not. Just as there is nothing unique in the manner in which health-and-safety regulations lead to economic losses, there is also nothing distinctive about the way in which health-and-safety regulations (as opposed to other types of government interventions) produce ancillary harms. As a result, we view health-health analysis - the study of ancillary risks to health mediated by economic transformations-as an instance of risk tradeoffs.

37 For example, different authors mean different things by "health-health tradeoffs." Sunstein uses the term "health-health tradeoff" synonymously with risk-risk tradeoff, to refer to situations where "the diminution of one health risk simultaneously increases another health risk." Sunstein, $63 \mathrm{U}$ Chi L Rev at 1535 (cited in note 3). Randall Lutter and John Morrall use the term to convey a risk tradeoff mediated by a decline in overall wealth. See Randall Lutter and John F. Morrall III, Health-Health Analysis: $A$ New Way to Evaluate Health and Safety Regulation, $8 \mathrm{~J}$ Risk \& Uncertainty 43, 44-48 (1994). 


\section{A. Direct Risk Tradeoffs}

What we refer to as direct risk tradeoffs embrace a range of phenomena in which the very act of regulating the target risk itself brings about ancillary risks. Perhaps the paradigmatic examples of such direct tradeoffs are the negative side effects associated with medical interventions. ${ }^{3 .}$ Known as iatrogenic disease or injury, this phenomenon is widespread and serious. A recent study found that 3.7 percent of hospitalizations brought on care-induced effects, of which 14 percent were fatal. ${ }^{39}$ Overall, iatrogenic disease or injury is responsible for more than 7.5 percent of the total deaths in the country every year. ${ }^{40}$ As one commentator has noted: "[T]he medical care component of society's risk regulation regime is a source of quite significant countervailing risks." ${ }^{41}$

The pattern of well-intentioned actions or decisions bringing about negative side effects is also familiar in health, safety, and environmental regulations. ${ }^{42}$ For example, the health risks posed by white asbestos (prevalent in schools and other public buildings) are minimal, while its removal "stirs up and sends into the air white asbestos fibers that would otherwise remain in place, thus threatening removal workers" - with the result that "removal is likely more dangerous than doing nothing." ${ }^{\prime 3}$ Requiring that children's pajamas be treated with Tris (2,3-dibromopropyl phosphate) protected the children from fire but enhanced their risk of developing certain cancers. ${ }^{4}$ And policies to reduce the amount of chlorine in water because of its carcinogenic properties at the same time may increase exposure to the microbial diseases that had formerly been killed by the chlorine.

38 See Wiener, 9 Risk at 39 \& n 1 (cited in note 35) (presenting a number of studies on iatrogenesis).

39 Id at 46, citing Paul C. Weiler, et al, $A$ Measure of Malpractice: Medical Injury, Malpractice Litigation, and Patient Compensation 43-44 (Harvard 1993) (presenting the results of a study by the Harvard Medical Practice Study Group).

40 Id at 47.

41 Id at 48.

42 See id at 40 (arguing that iatrogenesis and risk tradeoffs in the regulatory context are conceptually similar). See also id at 41 n 14, citing Daniel Patrick Moynihan, Iatrogenic Government: Social Policy and Drug Research, 62 Am Scholar 351 (1993) (discussing the negative side effects of drug regulation). In the context of this discussion we convey by "regulatory interventions" not just rules promulgated by administrative agencies, but also collective decisions to promote health and safety more broadly.

43 Breyer, Breaking the Vicious Circle at 12 (cited in note 5) (discussing asbestos regulation as an example of agency tunnel vision). For a helpful catalog of risk tradeoffs, see Graham and Wiener, Confronting Risk Tradeoffs at 12-17 (cited in note 2).

44 See Chris Whipple, Redistributing Risk, 9 Reg 37, 38 (May/June 1985) (describing how this regulation was the source of new risk).

45 See Graham and Wiener, Confronting Risk Tradeoffs at 15 (cited in note 2), citing Christopher Anderson, Cholera Epidemic Traced to Risk Miscalculation, 354 Nature 255 (1991) (providing an example of a risk miscalculation). 
A direct risk tradeoff can take a toll in health, safety, or environmental integrity in multiple ways. The intervention may itself pose a health risk, as in the asbestos example above or when the implementation of safety equipment takes a toll in lives and health. ${ }^{46}$ Alternatively, the intervention may reduce the benefits formerly provided by a nowregulated substance or procedure. Such is the case in the chlorine example above or, for instance, when the removal of asbestos takes a toll in reduced fire safety. The same is true of a regulation that aims to eliminate altogether a chemical that is "harmful to health at high doses [but] turns out to produce beneficial effects at low doses." This phenomenon is known as "hormesis" and is usually reflected in a Ushaped dose response curve. ${ }^{48}$ Sodium nitrite, for instance, is at once a carcinogen and an important protection against botulism. When regulating sodium nitrite, the health benefits in terms of cancer reductions must be compared with the increasing risks of botulism. ${ }^{49}$ Regardless of precisely how direct tradeoffs take effect, they (among the various types of tradeoffs we identify) feature the most straightforward connection between the regulation and the ancillary risks to which it gives rise.

Not only have direct risk tradeoffs been examined in the scholarly literature, but they have also received attention in the federal courts. In American Trucking Associations, Inc v EPA, ${ }^{50}$ the D.C. Circuit recognized a legal challenge to an environmental regulation based on the agency's failure to consider a direct risk tradeoff. In the portion of the case that was later reviewed by the Supreme Court, the D.C. Circuit held that the discretion enjoyed by the Environmental Protection Agency ("EPA") Administrator in revising National Ambient Air Quality Standards ("NAAQS") for ozone and particulate matter was so broad as to spell an unconstitutional delegation of legislative authority to the agency. ${ }^{\text {s1 }}$ The appellate court also rejected an argument that the NAAQS be made subject to cost-benefit analysis, upholding

46 See Keeney and von Winterfeldt, 16(6) Interfaces at 14 (cited in note 35) (noting that one of the pathways causing indirect risks is "through the risks associated with constructing and operating pollution abatement equipment").

47 Cass R. Sunstein, The Arithmetic of Arsenic *28 \& m 130-31, Working Paper No 01-10 (AEI-Brookings Joint Center for Regulatory Studies 2001), available online at <http://www.aei.brookings.org/publications/working/working_01_10.pdf (visited Feb 16,2002).

48 See id.

49 See Lave, Strategy of Social Regulation at 15 (cited in note 1) (discussing the beneficial and adverse health effects of sodium nitrite).

50175 F3d 1027 (DC Cir 1999), revd in part as Whitman v American Trucking Associations, Inc, 531 US 457 (2001). The same D.C. Circuit panel recently held on remand that the EPA's NAAQS for particulate matter and ozone were not arbitrary and capricious. See American Trucking Associations, Inc v EPA, 283 F3d 355, 358 (DC Cir 2002).

51 See American Trucking, 175 F3d at 1034. 
its decision in Lead Industries Association $v E P A^{s 2}$ prohibiting costbenefit analysis in this area. ${ }^{53}$

Before the D.C. Circuit, petitioners also argued that the EPA failed to undertake a thorough analysis of the health effects of the new NAAQS, as the statute required. They based their claim on the EPA's failure to consider adequately the potentially salutary effects of tropospheric ozone in shielding people from ultraviolet rays, thereby reducing the risks of cataracts and skin cancers. ${ }^{\text {st }}$ In the view of petitioners, the EPA was required to consider not only the deleterious effects of ozone on respiration, but also the ancillary harm of ozone regulation for skin and eyes. Section 109 of the Clean Air Act requires that the EPA base its NAAQS on published "criteria", that, according to Section 108, must reflect "the latest scientific knowledge useful in indicating the kind and extent of all identifiable effects on public health or welfare." ${ }^{, 56}$ According to petitioners, this language embraced both the negative and the positive effects of a regulated pollutant.

The EPA claimed that it was barred from considering these ancillary effects by the statute itself. ${ }^{\text {s }}$ Section 108 of the Clean Air Act requires the EPA to consider "all identifiable effects" of "pollutant $[s]$. ."s The EPA understood the requirement to refer only to the consideration of the effects of substances insofar as they were pollutants, and not, in other words, insofar as they produced health benefits.

Accepting the petitioners' direct risk tradeoff argument, Judge Williams refused to accord deference under Chevron USA Inc v Natural Resources Defense Council, Inc ${ }^{\infty}$ to the agency's interpretation, reasoning first that the statute was unambiguous in requiring agency

$52 \quad 647$ F2d 1130 (DC Cir 1980).

53 See American Trucking, 175 F3d at 1040.

54 See id at 1051-53. See generally Randall Lutter and Christopher Wolz, UV-B Screening by Tropospheric Ozone: Implications for the National Ambient Air Quality Standard, 31 Envir Sci \& Tech 142A (1997) (arguing that the EPA should consider the health benefits of tropospheric ozone in setting NAAQS). See also Gary E. Marchant, Turning Two Blind Eyes: The EPA's Failure to Consider Costs and Health Disbenefits in Revising the Ozone Standard, 11 Tulane Envir L J 261,272-80 (1998) (arguing that the EPA should consider both harmful and protective health effects of this type of ozone).

ss Pub L No 101-549, 104 Stat 2399, codified at 42 USC § 7409(b)(1)-(2) (1994).

5642 USC $\$ 7408(a)(2)$ (emphasis added).

57 See American Trucking, 175 F3d at 1051-52.

$58 \quad 42$ USC $\$ 7408(\mathrm{a})(2)$ (emphasis added).

59 See American Trucking, 175 F3d at 1051. See EPA, Responses to Significant Comments on the 1996 Proposed Rule on the National Ambient Air Quality Standards for Ozone 128 (1997) (stating that the EPA strongly disagrees that such benefits should be considered), cited in Marchant, 11 Tulane Envir L J at 272 n 74 (cited in note 54). The EPA also pressed various other statutory claims, arguing, for example, that the beneficial aspects of ozone were properly covered by Title VI of the Clean Air Act, 42 USC \$\$ 7671-71q (1994), and not Sections 108 and 109, 42 USC $\S \$ 7408-09$. See American Trucking, 175 F3d at 1052.

60467 US 837, 843-45 (1984) (holding that courts should to defer to an agency's reasonable interpretation of an ambiguous statute). 
attention to the direct risk tradeoff, and second, that the EPA's interpretation was facially unreasonable." "[I]t seems bizarre," wrote Judge Williams, "that a statute intended to improve human health would, as EPA claimed at argument, lock the agency into looking at only one half of a substance's health effects in determining the maximum level for that substance." EPA for further consideration of the risk tradeoff. ${ }^{63}$ Previously, the D.C. Circuit has also been receptive to arguments grounded in direct risk tradeoffs. ${ }^{64}$ Nevertheless, the clarity of Judge Williams's analysis,

61 See American Trucking, 175 F3d at 1052.

62 Id. A critic of our presentation of Judge Williams's opinion-or of our account of direct risk tradeoffs more generally-might argue that the reduction in the benefits of ozone is not an ancillary effect of the regulation but a primary effect. In other words, precisely because the link between the regulatory intervention and the effect is so close, one might question whether this is, in fact, an ancillary effect at all. We argue that, as an analytic matter, the primary effect of the regulation ought to be construed narrowly as its direct effect on the target risk. Since the observed escalation in risk here involved not the target risk but another risk altogether, we think it appropriate to treat the possibility of skin cancer as an instance of an ancillary effect-and to treat Judge Williams's analysis, therefore, as drawing on a risk tradeoff.

63 Id at 1053. In the wake of the D.C. Circuit's opinion in American Trucking, the EPA was compelled to study the risk tradeoffs of its proposed revised standards for ambient ozone. See id at 1052-53. Just before the change in administrations, EPA Administrator Browner signed a proposed response to the remand. See EPA, National Ambient Air Quality Standards for Ozone: Proposed Response to Remand, available online at <http://www.epa.gov/ttn/oarpg/t1/ fr_notices/uvbnotic.pdf (visited Apr 20,2002). That response was made subject to review by the Card Memorandum of January 20,2001, which prohibited agencies from undertaking regulation without the approval of an agency head appointed by incoming President Bush. See Andrew H. Card, Jr., Assistant to the President and Chief of Staff, Memorandum for the Heads and Acting Heads of Executive Departments and Agencies: Regulatory Review Plan (Jan 20,2001), available online at <http://www.whitehouse.gov/news/releases/20010123-4.html> (visited Apr 20,2002). On November 14, 2001, Administrator Whitman released the current EPA's proposed response, which is similar to the one proposed by the Clinton Administration. See EPA, National Ambient Air Quality Standards for Ozone: Proposed Response to Remand; Proposed Rule, 66 Fed Reg 57268 (2001). It indicates that the EPA has studied the effects of tropospheric ozone on melanomas and cataracts and has decided that the potential harms are negligible when compared to the health benefits of the new ozone standards. See id at 57278-86. See also EPA, Fact Sheet, Proposed Response to Remand: National Ambient Air Quality Standards for Ozone: Beneficial Aspects of Ground-Level-Ozone (Oct 31, 2001), available online at <http://www.epa.gov/ttn/oarpg/t1/fact_sheets/naaqso_fs.pdf $>$ (visited Apr 20, 2002) (reaffirming the eight-hour standard after carefully considering the available technical and scientific literature). Randall Lutter and Howard Gruenspecht-the former is the author of two studies on which the industry group challengers relied in the D.C. Circuit litigation-have argued that the EPA did not give sufficient weight to the scientific evidence in considering the risk tradeoff on remand. See Randall Lutter and Howard Gruenspecht, Assessing Benefits of Ground Level Ozone: What Role for Science in Setting National Air Quality Standards, 15 Tulane Envir L J 85, 94-95 (2001) ("In the twenty months after the Court's decision, the EPA made no effort to update its risk assessments [or] develop new information."). See also Randall Lutter, Clean Air and Dirty Science, Policy Matters No 02-12 (AEI-Brookings Joint Center for Regulatory Studies 2002), available online at <http://www.aei.brookings.org/publications/policy/policy_02_12.asp> (visited Apr 19, 2002). Ultimately, the D.C. Circuit might be asked to review the quality of the EPA's risk tradeoff analysis. It is worth underscoring that the EPA was required to undertake a risk tradeoff analysis in this case, and probably will have to do the same in future cases.

64 See, for example, National Resources Defense Council, Inc v EPA, 655 F2d 318 (DC Cir 
the absence of a dissent on this issue by Judge David Tatel, ${ }^{6 s}$ and the fact that the EPA did not seek review of this aspect of the decision by the Supreme Court as it did with respect to the finding of an impermissible delegation, ${ }^{66}$ suggest that arguments grounded in direct risk tradeoffs may play a prominent role in the judicial review of administrative action.

\section{B. Substitution Effects}

Sometimes a regulation will bring about a risk tradeoff when it effects a shift from one product or process to another, which in turn gives rise to risks of its own. ${ }^{67}$ For instance, banning artificial sweeteners called cyclamates because of their carcinogenic properties led consumers to turn to saccharin, which itself was shown to cause cancer. ${ }^{68}$ Regulations aimed at making nuclear power generation safer might, by imposing large costs, encourage reliance on other risky methods of energy production.

Even though the causal relationship between the regulatory intervention and the ancillary effect is more mediated in the context of substitution effects, the courts have struck down regulations on the basis of failure to consider these types of tradeoffs just as they have in

1981). In that case, the EPA itself advanced a pure risk tradeoff argument in order to justify its decision to permit nitrogen oxides $\left(\mathrm{NO}_{\mathrm{z}}\right.$ ) waivers to various manufacturers under Section 202(b)(6)(B) of the Clean Air Act, Pub L No 89-272, 79 Stat 992 (1965), codified at 42 USC § 7521(b)(6)(B), redesignated as 42 USC \$ 7521(b)(3)(B), repealed Pub L No 101-549, 104 Stat 2529 (1990). See Natural Resources Defense Council, 655 F2d at 342 . Granting the waivers would have increased overall $\mathrm{NO}_{x}$ levels but at the same time would have led to a reduction in ambient particulate matter, another criteria pollutant regulated under Section 109 of the Clean Air Act. See 42 USC \$ 7409(b) (1994). Judge Abner Mikva upheld the EPA decision to grant the waivers against a challenge by the environmental group, reasoning that "[i]t was perfectly proper for the EPA to bear in mind this trade-off [between refusing the waivers and thereby increasing particulate matter] in evaluating the public health impact of $\mathrm{NO}_{\mathrm{x}}$ waivers." Natural Resources Defense Council, 655 F2d at 342. Earlier case law also supports pure risk tradeoff analysis. Judge Harold Leventhal reasoned, for instance, that the criteria set out in Section 111 of the Clean Air Act "require the Administrator to take into account counter-productive environmental effects of a proposed standard, as well as economic costs to the industry." Portland Cement Association v Ruckelshaus, 486 F2d 375, 385 (DC Cir 1973).

65 Judge Tatel dissented vigorously from the court's holding that Section 109 of the Clean Air Act represents an unconstitutional delegation of legislative power to the EPA. See American Trucking, 175 F3d at 1057-62 (Tatel dissenting).

66 See American Trucking, 531 US at 495.

67 See Whipple, 9 Reg at 37 (cited in note 44) ("We ban some substances or technologies or practices on grounds of risk, only to see less desirable and, in many cases, more hazardous alternatives chosen.").

68 See Graham and Wiener, Confronting Risk Tradeoffs at 14 (cited in note 2) (describing the risks involved in regulation); Whipple, 9 Reg at 38 (cited in note 44) (same).

69 See Stephen Breyer, Vermont Yankee and the Courts' Role in the Nuclear Energy Controversy, 91 Harv L Rev 1833, 1835-36 (1978) (reviewing the potential harmful effects of nuclear power regulation). 
the context of direct risk tradeoffs. ${ }^{70}$ In Competitive Enterprise Institute $v$ National Highway Traffic Safety Administration, ${ }^{11}$ Judge Williams agreed with Competitive Enterprise Institute ("CEI") that the National Highway Traffic Safety Administration ("NHTSA") had failed to consider adequately the potential implications that a more stringent corporate average fuel economy ("CAFE") standard might have for highway safety. Judge Williams found persuasive CEI's contention that by implementing the more stringent standard, NHTSA effectively caused the price of larger, safer cars to increase, which in turn meant that more consumers would be forced either to drive their older, less safe cars, or else to buy smaller, less safe cars than they would have absent the regulation." "By making it harder for consumers to buy large cars, the 27.5 miles per gallon (mpg) standard will increase traffic fatalities if, as a general matter, small cars are less safe than big ones. They are, as NHTSA itself acknowledges.",73

Here, the ancillary harm was mediated by a consumer reaction to changed market conditions. The regulation affected the production of automobiles as well as consumer demand in such a way as to bring about new risks. ${ }^{74}$ Writing in dissent, Judge Mikva, without rejecting the risk tradeoff argument in principle, nevertheless took the view that the agency had considered the tradeoff sufficiently. "The majority's predictions about effects on the behavior of both manufacturers and consumers and the likely safety consequences of these anticipated effects ... represent musings that the agency considered and reasonably rejected.., ${ }^{76}$

70 See text accompanying notes 60-63.

71956 F2d 321 (DC Cir 1992).

72 See Robert W. Crandall, Policy Watch: Corporate Average Fuel Economy Standards, $6 \mathrm{~J}$ Econ Persp 171, 178 (1992) (explaining how stringent CAFE standards can lead to decreased automobile safety); Robert W. Crandall and John D. Graham, The Effect of Fuel Economy Standards on Automobile Safety, 32 J L \& Econ 97, 101-15 (1989) (finding that NHTSA's CAFE standard kills thousands of people per year). Judge Williams's opinion cites the study by Crandall and Graham. See Competitive Enterprise Institute, $956 \mathrm{~F} 2 \mathrm{~d}$ at 327.

73 Competitive Enterprise Institute, $956 \mathrm{~F} 2 \mathrm{~d}$ at 326.

74 In another case, Judge Buckley (joined by Judges Williams and Robinson) accepted a risk tradeoff argument, grounded in substitution effect, invoked by the U.S. Consumer Product Safety Commission. See Consumer Federation of America v U.S. Consumer Product Safety Commission, 883 F2d 1073, 1078-79 (DC Cir 1989). The Consumer Federation of America ("CFA") disputed "the Commission's position that a ban on methylene chloride is undesirable because manufacturers might respond to a ban by substituting other more harmful chemicals for methylene chloride." Id at 1079. The court rejected the CFA's argument that "the Commission should deal with this potentiality by regulating the substitutes that manufacturers use rather than leaving methylene chloride on the market." Id.

75 See Competitive Enterprise Institute, 956 F2d at 327-30 (Mikva dissenting).

76 Id at 329. One observer has emphasized that the debate between Judges Williams and Mikva was about the extent to which the agency had considered the risk tradeoff argument, and not its facial plausibility. See Jay D. Wexler, Risk in the Balance, 30 Conn L Rev 225, 253 (1997) (" $[T]$ he key debate ... was not over the issue of whether the agency had to consider such risks, 
Another case addressing substitution effects is Corrosion Proof Fittings $v E P A .{ }^{n}$ In that case, an industry group challenged an EPA rule promulgated under the Toxic Substances Control Act ("TSCA") that aimed to reduce exposure to asbestos. The Fifth Circuit struck down the rule partly because the EPA failed to take into account the fact that the likely substitutes for asbestos would themselves be carcinogenic: "Eager to douse the dangers of asbestos, the agency inadvertently actually may increase the risk of injury Americans face. The EPA's explicit failure to consider the toxicity of likely substitutes thus deprives its order of a reasonable basis."

\section{Lulling Effects}

The chain of events mediating between the regulatory intervention and the ancillary harm need not take the form of a substitution effect. Under the banner of "lulling effects," Viscusi discusses what is essentially a cognitive-psychological transformation wrought by health-and-safety regulation. The introduction of a safety measure, he argues, can have the effect of "produc[ing] misperceptions that lead consumers to reduce their safety precautions because they overestimate the product's safety." Thus, a regulation requiring that drugs be dispensed in child-safe packages gives rise to a mediated risk tradeoff when the rule has the effect of lulling parents into thinking that they no longer need to take precautions about storing medications outside the reach of their young children. ${ }^{\mathrm{g}}$ In a similar vein, there has been a

but over the extent to which they have to consider and justify their conclusions regarding the risks."). Indeed, Judge Mikva endorsed an argument based on pure risk tradeoff analysis in $\mathrm{Na}$ tional Resources Defense Council, Inc, v EPA, 655 F2d 318, 341-42 (DC Cir 1981).

77947 F2d 1201 (5th Cir 1991).

78 Id at 1221 . The approach to risk tradeoffs embodied in these two cases should be contrasted with the treatment of this issue in the previous decade. For example, Environmental Defense Fund, Inc v EPA, 510 F2d 1292 (DC Cir 1975), presented numerous challenges to the EPA's decision to suspend the registration and ban the manufacture of the pesticides aldrin and dieldrin. See id at 1295-96. Shell Chemical Company challenged the ban, arguing among other things that "[b]ecause heptachlor [the likely substitute] presents an identical cancer risk ... the Administrator's suspension of aldrin/dieldrin does not 'prevent' an imminent hazard as required by the statute." Id at 1303. Judge Leventhal rejected that rationale, reasoning, "There is no law that says that all evils must be attacked at the same time and at the same rate." Id.

79 Viscusi, Fatal Tradeoffs at 225 (cited in note 9). Lulling effects bear a strong conceptual resemblance to the phenomenon of moral hazard, whereby insurance increases the likelihood that certain undesirable events will transpire by creating perverse incentives among the insured to behave more carelessly than they would absent the insurance. See, for example, Tom Baker, On the Genealogy of Moral Hazard, 75 Tex L Rev 237, 238-39 (1996).

so See Viscusi, Fatal Tradeoffs at 234-42 (cited in note 9) (arguing that the implementation of safety caps on aspirin bottles lulled people into a false sense of safety, thereby undermining the utility of the regulation); W. Kip Viscusi, Regulating Consumer Product Safety 73-80 (AEI 1984) (critiquing consumer product safety regulation of child-resistant bottle caps). See also Whipple, 9 Reg at 41, 44 (cited in note 44), citing Gilbert Fowler White, Human Adjustment to Floods: A Geographical Approach to the Flood Problem in the United States *206, Research Pa- 
recent increase in unsafe sex among men at risk for HIV, possibly as a result of a lulling effect induced by overestimating greater success in the medical community at managing the disease.

\section{Health-Health Tradeoffs}

Although certain authors regard health-health tradeoffs ${ }^{\text {s }}$ as a distinct analytic phenomenon, they are best thought of as instances of risk tradeoffs in which the chains of events mediating between regulatory intervention and ancillary harm take a distinctive form-namely a reduction in overall social wealth, which is thought to lead to a reduction in overall social health. Proponents of this methodology begin with the premise that wealthier people and societies are also healthier. ${ }^{*}$ They argue that because environmental and health-and-safety regulations impose large economic costs on society, they have negative health consequences. ${ }^{8+}$ This negative effect must be weighed against the benefits of reducing target risks. " $[\mathrm{R}]$ egulatory expenditures represent opportunity costs to society that divert resources from other uses. These funds could have provided for greater healthcare, food, housing, and other goods and services that promote individual longevity.",

Ralph L. Keeney, a prominent proponent of health-health tradeoff analysis, has argued that each $\$ 7.25$ million of costs of regulation

per No 29 (University of Chicago Department of Geography 1942) (arguing that the building of dams encouraged people to move to flood plains, which resulted in greater overall loss of life than had been experienced before the dams were built).

81 See American Health Consultants, CDC Stats Show Unsafe Sex Practices Are Increasing, AIDS Alert (Apr 1,1999), available online at <http://www.ahcpub.com/ahc_online/aa.html> (visited Oct 2, 2002).

82 We follow Lutter and Morrall in using the term "health-health tradeoffs" to denote reductions in health that flow from government-mandated expenditures on health regulation. See Lutter and Morrall, $8 \mathrm{~J}$ Risk \& Uncertainty at 44 (cited in note 37) ("Health-health analysis seeks to quantify the expected declines in health and safety that may be ascribed to the costs of complying with a regulation."). See generally Fred Kuchler, et al, Health Transfers: An Application of Health-Health Analysis to Assess Food Safety Regulations, 10 Risk 315 (1999).

83 See Wildavsky, Searching for Safety at 59-66 (cited in note 3); Wildavsky, 60 Pub Int at 25-28 (cited in note 3 ).

84 See Frank B. Cross, When Environmental Regulations Kill: The Role of Health-Health Analysis, 22 Ecol L Q 729, 731 (1995) (finding the theory "fundamentally sound"); Keeney, 10 Risk Anal at 147 (cited in note 3) ("[S]ome expensive regulations and programs intended to save lives may actually lead to increased fatalities.").

85 See, for example, Lutter and Morrall, $8 \mathrm{~J}$ Risk \& Uncertainty at 44 (cited in note 37) (noting how health-health analysis compares the expected decline in health and safety attributable to compliance costs with the direct benefits of regulation). Keeney's study, arguably the most influential in the area, "develops a model to estimate the number of excess deaths when the relationship between income and mortality risk is assumed to be an induced relationship." Keeney, 10 Risk Anal at 147 (cited in note 3) (emphasis added). He does not present a theoretic account for the existence of a causal nexus. See id.

86 Viscusi, 63 U Chi L Rev at 1452 (cited in note 9). 
may induce one statistical fatality. ${ }^{87}$ This estimate has become somewhat standard in the literature: Judge Williams makes reference to it in an important opinion, ${ }^{\mathbb{8}}$ and Justice Breyer refers to it as a conservative estimate in his book on risk regulation. ${ }^{\circledR 9}$ Keeney's figure, however, is in 1980 dollars. Converting to 1999 dollars, the $\$ 7.25$ million is equivalent to $\$ 14.7$ million. In a more recent study, three leading exponents of health-health tradeoffs argue that regulatory expenditures that rely on a valuation of a statistical human life over $\$ 15$ million per human life saved will have net counterproductive effects."

Health-health analysis has attracted considerable interest not only in academic circles, but on the federal bench as well. Distinguished judges such as Frank Easterbrook, ${ }^{, 2}$ Richard Posner, ${ }^{93}$ Stephen Williams, and most recently, Justice Breyer ${ }^{\text {ss }}$ have all explicitly embraced this version of risk tradeoff analysis in their judicial opinions. In particular, Judge Williams has evinced an interest in health-health tradeoffs on a number of occasions. In his concurring opinion in International Union, UAW v OSHA ("Lockout/Tagout"), Judge Williams

87 See Keeney, 10 Risk Anal at 155 (cited in note 3), relying on the data of E.M. Kitagawa and P.M. Hauser, Differential Mortality in the United States of America: A Study of Socioeconomic Epidemiology (Harvard 1973).

88 See International Union, UAW v OSHA ("Lockout/Tagout"), 938 F2d 1310, 1326 (DC Cir 1991) (Williams concurring).

89 See Breyer, Breaking the Vicious Circle at 23 \& $n 119$ (cited in note 5).

90 The conversion to 1999 dollars is performed employing a consumer price index from 1980 to 1999 of 2.022. See NASA, Consumer Price Index Inflation Calculator, available online at <http://www.jsc.nasa.gov/bu2/inflateCPI.html> (visited Apr 20, 2002).

91 See Randall Lutter, John Morrall, and W. Kip Viscusi, The Cost-Per-Life-Saved Cutoff for Safety-Enhancing Regulations, 37 Econ Inq 599, 605 (1999) (arguing that a $\$ 15$ million decrease in income is associated with the loss of an additional statistical life).

92 See International Union, UAW v Johnson Controls, Inc, 886 F2d 871, 918 (7th Cir 1989) (en banc) (Easterbrook dissenting) (arguing that removing women from jobs in which they run the risk of lead exposure might create more overall risk for their children because "[t]he net effect of lower income and less medical care could be a reduction in infants' prospects"), revd, 499 US 187 (1991).

93 See American Dental Association v Martin, 984 F2d 823, 826 (7th Cir 1993) (Posner) (reasoning that OSHA-by not taking into account lives sacrificed because of increased health care costs passed on to consumers-exaggerated the number of lives saved by mandatory workplace precautions against AIDS).

94 See New York State Ophthalmological Society v Bowen, 854 F2d 1379, 1395 n 1 (DC Cir 1988) (Williams concurring in part and dissenting in part) ("[E]xtravagant expenditures on health may in some instances affect health adversely, by foreclosing expenditures on itemshigher quality food, shelter, recreation, etc., that would have contributed more to the individual's health than the direct expenditure thereon."); Building and Construction Trades Department $v$ Brock, 838 F2d 1258, 1267 (DC Cir 1988) (Williams) ("[L]eaning towards safety may sometimes have the perverse effect of increasing rather than decreasing risk.").

95 See American Trucking, 531 US at 490-96 (Breyer concurring in part and concurring in the judgment). We discuss Justice Breyer's concurrence in the text accompanying notes 153-61.

96938 F2d 1310 (DC Cir 1991). From the fact that Judge Williams wrote the majority opinion in this case as well, it appears that the other members of the panel were not interested in endorsing the risk tradeoff analysis. 
rejected the union's contention that less stringent regulation was necessarily adverse to worker safety:

More regulation means some combination of reduced value of firms, higher product prices, fewer jobs in the regulated industry, and lower cash wages. All the latter three stretch workers' budgets tighter (as does the first to the extent that the firms' stock is held in workers' pension trusts). And larger incomes enable people to lead safer lives."

\section{THE RISE OF THE RISK TRADEOFF SUBSTATE}

Risk tradeoff analysis has become a pervasive feature of the contemporary regulatory state. We appear to have entered what Judge Williams has called the "Era of 'Risk-Risk."” Indeed, we might say that risk tradeoff analysis now supplies the foundation of its own substate, as part of the larger "Cost-Benefit State" to which Sunstein has drawn attention. ${ }^{99}$ This Part aims to highlight the prominence of the methodology in current regulatory practice and noteworthy calls for its wider application.

In Part II.A, we survey various academic proposals for the wider application of risk tradeoff analysis. Then, in Part II.B, we turn our attention to the regulatory process. We first discuss various congressional initiatives to broaden the use of risk tradeoff analysis in administrative rulemaking. Then we explore the role of risk tradeoff analysis in OMB's review of regulation and to a lesser extent in the decisions of administrative agencies. Finally, focusing on Justice Breyer's concurring opinion in American Trucking, we show how risk tradeoff analysis has come to play a prominent role in the courts.

\section{A. Academic Proponents}

Recent years have witnessed intense academic interest in the broader application of risk tradeoff analysis in the regulatory process. We focus on a number of different visions of how to implement risk tradeoff analysis in the regulatory state. Graham and Wiener offer the most developed account of the potential role of risk tradeoff analysis in the legislative, executive, and judicial branches. ${ }^{100}$ Sunstein likewise has expressed the view that risk tradeoff analysis ought to be incorporated into every branch of government. ${ }^{101}$

97 Id at 1326, citing Keeney, 10 Risk Anal at 158 (cited in note 3 ).

98 Williams, $63 \mathrm{U}$ Chi L Rev at 1375 (cited in note 7).

99 See Sunstein, 48 Stan L Rev at 249 (cited in note 8).

100 See Wiener and Graham, Resolving Risk Tradeoffs at 242-71 (cited in note 34).

101 Viscusi is another strong proponent of risk tradeoff analysis, particularly health-health analysis, though he has a less developed vision for institutional reform than Graham and Wiener 
Graham and Wiener recognize that their call for greater reliance on risk tradeoff analysis requires substantive changes in the structures of decisionmaking at various stages in the regulatory process. ${ }^{102}$ On the legislative front, Graham and Wiener would implement a number of important changes. First, they call for Congress to require by statute that risk tradeoff analysis of all future legislative initiatives be undertaken. ${ }^{1 \cdot 3}$ Technical assistance in assembling reports on risk tradeoffs might be supplied by expert staff members. Second, they call for the creation of a "Joint House-Senate Committee on Risk" to oversee legislative risk regulation initiatives and guard against the possibility of risk tradeoffs. Third, they would urge Congress to rewrite certain statutes in a way that does not preclude cost-benefit analysis, in order to ensure that risk tradeoff analysis can be employed. ${ }^{104}$ Finally, they advocate amending health, safety, and environmental laws so that those laws require agencies to "reduce overall risk," rather than relying on the vaguer language currently in place, such as the statutory emphasis on "protect[ing] the public health.",

With respect to the executive branch, Graham and Wiener favor an executive order, modeled on Executive Orders 12291 and 12866, ${ }^{106}$ explicitly requiring agency staff to undertake risk tradeoff analysis of proposed regulations. ${ }^{107}$ Graham and Wiener acknowledge that the process of generating a risk tradeoff analysis and having it reviewed by OIRA might become an "iterative process" if, for example, OIRA scrutiny were to reveal ancillary harms that the agency had failed to

or Sunstein. See Viscusi, 63 U Chi L Rev at 1455-60 (cited in note 9) (criticizing prior attempts at reform without putting forward a program of his own).

102 "[B]ecause so many risk tradeoffs in decisionmaking are driven by structures that induce narrow and bounded decisions, proposing a new method of analysis will have only limited impact unless it is complemented by institutional reforms that enable and impel decisionmakers to pursue a more comprehensive analysis of risk." Wiener and Graham, Resolving Risk Tradeoffs at 243 (cited in note 34 ).

103 See id at 250. They leave open the possibility that such an investigation might be undertaken when a bill is reported out of committee, subcommittee, or brought up for action on the floor. See id. See also John D. Graham, Legislative Approaches to Achieving More Protection against Risk at Less Cost, 1997 U Chi Legal F 13, 47 (calling for Congress to require consideration of risk tradeoffs in all regulatory determinations, and to impose a "more good than harm" requirement in new regulatory programs).

104 See Wiener and Graham, Resolving Risk Tradeoffs at 250-51 (cited in note 34). Even where cost-benefit analysis is prohibited by statute, OIRA can review a regulation for compliance with risk tradeoff analysis. See text accompanying notes 138-41,183-88.

105 Wiener and Graham, Resolving Risk Tradeoffs at 251 (cited in note 34).

1063 CFR $§ 638$ (1993). President Clinton issued Executive Order 12866 to replace Executive Order 12291 . Id at $\$ 11$. The Clinton executive order shares with the Reagan executive order a commitment to the cost-benefit analysis of regulation. For a general discussion of this similarity, see Richard H. Pildes and Cass R. Sunstein, Reinventing the Regulatory State, $62 \mathrm{U}$ Chi L Rev 1 (1995).

107 See Wiener and Graham, Resolving Risk Tradeoffs at 254-55 (cited in note 34). 
consider. ${ }^{108}$ Thus, they would like OIRA to develop the know-how to scrutinize risk assessments. ${ }^{109}$

Graham and Wiener also make a number of bolder suggestions, including the creation of a "primary care" agency, possibly in the White House, which could then treat a regulatory problem holistically, analyzing potential risk tradeoffs that more narrowly conceived agencies would miss. The primary care agency would refer individual aspects of a global problem to "specialist" agencies as needed. ${ }^{110}$ Alternatively, Graham and Wiener imagine that within a given complex agency, oversight of risk across various program offices might be consolidated in a position entitled "Undersecretary for Risk Management." "11 They also call for the centralization of the scientific analysis of risk in a single body. ${ }^{112}$

Finally, Graham and Wiener argue that courts, when taking a "hard look" at agency decisionmaking, should consider whether the agency adequately considered risk tradeoffs. ${ }^{113}$ When there is strong reason to suspect that the ancillary harms outweigh the good accomplished by regulation, they would have courts strike down the regulation as arbitrary and capricious under the Administrative Procedure Act ("APA"). ${ }^{114}$ The authors emphasize, however, that judges are not ideally situated to undertake substantive inquiries into risk tradeoffs and should be thought of as a last line of defense if the oversight procedures within the executive branch fail. ${ }^{115}$

108 Id at 255.

109 See id.

110 Id at 257. Graham and Wiener's account of risk tradeoffs draws heavily on this medical metaphor. See, for example, id at 270 (referring to the need to implement in the regulatory arena the "whole patient" approach of modern medicine and gestalt psychology).

111 Id at 258.

112 See id.

113 See id at 262. The genesis of the "hard look" doctrine has been traced to an influential essay by Judge Leventhal of the D.C. Circuit. See Harold Leventhal, Environmental Decisionmaking and the Role of the Courts, $122 \mathrm{U}$ Pa L Rev 509, 514 (1974) ("The court does not make the ultimate decision, but it insists that the official or agency take a 'hard look' at all relevant factors.").

114 See Wiener and Graham, Resolving Risk Tradeoffs at 262-63 (cited in note 34), referring to the APA, 5 USC § 706(2)(A) (1994). See also Edward W. Warren and Gary E. Marchant, "More Good Than Harm": A First Principle for Environmental Agencies and Reviewing Courts, 20 Ecol L Q 379, 381-82 (1993) (defining as beneficial regulations that "produced a net benefit to society, taking account of risk-risk tradeoffs and the various regulatory options open to the promulgating agency"); W. Kip Viscusi, Risk-Risk Analysis, 8 J Risk \& Uncertainty 5, 15 (1994) ("If in fact these regulations do more harm than good, then they should not be pursued."); Antonin Scalia, Reagulation-The First Year, 6 Reg 19, 19-20 (Jan/Feb 1982) (maintaining that a rule that probably "does more harm than good" should be struck down as arbitrary and capricious).

115 See Wiener and Graham, Resolving Risk Tradeoffs at 262-63 (cited in note 34). The authors advance a number of other suggestions. They would interpret statutory calls for agency "reasonable[ness]" to imply the need for consideration of risk tradeoffs. Id at 263-64. To that end, they would require risk tradeoff analysis even when a statute has been interpreted to pre- 
Sunstein refers to risk tradeoffs as "a pervasive problem in risk regulation, one that helps account for regulatory failure, that is an intriguing part of cost-benefit assessment, and that is only now receiving public attention." ${ }^{115}$ Like Graham and Wiener, to whom he acknowledges a general debt, ${ }^{117}$ he makes a number of concrete policy suggestions.

With respect to Congress, Sunstein recommends establishing a new committee with the mandate to study the risk portfolios of various pieces of proposed legislation, and to initiate revisions where new laws would increase risk. ${ }^{118}$ Sunstein would empower the committee to introduce what he refers to as "corrective legislation" in cases in which such proposals would increase risk. ${ }^{119} \mathrm{He}$ also advocates an amendment to the APA requiring that "[a]gencies shall ensure, to the extent feasible, that regulations do not create countervailing risks that are greater than those of regulated risks." ${ }^{120}$ Since Sunstein, unlike Graham and Wiener, embraces health-health tradeoffs, ${ }^{121}$ his proposed reform of the APA would presumably apply to them as well as to direct risk tradeoffs.

Sunstein's principal suggestion for the executive branch is similar to Graham and Wiener's. He would have OIRA supervise agency decisionmaking on risk regulation issues to ensure that risk tradeoffs are taken into account. ${ }^{12}$ Together with Robert Hahn, Sunstein has also recently proposed a new executive order that would explicitly require agencies to "explore and explain whether any regulation will create significant new risks of any kind, and if so," to quantify them.

With respect to the courts, Sunstein has two specific proposals. First, when a statute does not explicitly require or forbid risk tradeoff analysis and when the agency carried out such an analysis, Sunstein would require courts to defer to that agency decision. Specifically, he endorses a new interpretive principle to the effect that "agencies are permitted to minimize net risks to life and health, a principle that

\footnotetext{
clude cost-benefit analysis. See id at 264-65. They would also broaden the rules of standing to allow the victims of ancillary harms to bring suit against the offending agency. See id at 265 .

116 Sunstein, $63 \mathrm{U}$ Chi L Rev at 1535 (cited in note 3).

117 Id at $1535 \mathrm{n} 17$.

118 See id at 1567.

119 Id.

120 Sunstein, 48 Stan L Rev at 296 (cited in note 3) (citations omitted).

121 See Sunstein, 63 U Chi L Rev at 1543-49 (cited in note 3) (discussing how health and wealth are correlated).

122 See id at $1568-69$.

123 Robert W. Hahn and Cass R. Sunstein, A New Executive Order for Improving Federal Regulation?: Deeper and Wider Cost-Benefit Analysis *49, Working Paper No 02-4, (AEIBrookings Joint Center for Regulatory Studies 2002), available online at <http:/ www.aei.brookings.org $>$ (visited Apr 19, 2002).
} 
Congress can overcome only with a clear statement to the contrary."124 Second, and more generally, he would require courts to take a "hard look" at agency decisions that failed to undertake risk tradeoff analysis. He does not, however, argue-as do other commentators, including Graham and Wiener - that courts should strike down as "arbitrary and capricious" regulations that do not meet a substantive "more good than harm" test.

\section{B. Risk Tradeoffs in Current Regulatory Practice}

Regardless of the fate of the commentators' policy proposals, risk tradeoff analysis is already an important feature of the administrative state. In the remainder of this Part, we highlight the importance of this methodology by surveying developments in the Congress, OMB, the agencies, and the courts.

\section{Congress.}

Efforts to pass legislation requiring federal agencies to consider the efficacy and cost-effectiveness of regulations began with the $103 \mathrm{~d}$ Congress in 1992. ${ }^{125}$ But it was with the Contract with America in 1994 that Congress first revealed an appetite for comprehensive regulatory improvement legislation. ${ }^{126}$ The 104th, 105th, and 106th Congresses all considered legislation that would have required administrative agencies to subject proposed regulations to risk assessment and costbenefit analysis. ${ }^{27}$ Although regulatory reform seems temporarily to

124 Sunstein, $63 \mathrm{U}$ Chi L Rev at 1562 (cited in note 3) (emphasis omitted). This canon would become unnecessary if Sunstein's suggested amendment to the APA were enacted.

125 These early legislative initiatives focused exclusively on the EPA. See Environmental Technologies Act of 1994, HR 3870, 103d Cong, 2d Sess (Feb 22, 1993) (proposing the promotion of research and development of environmental technologies); Risk Assessment Improvement Act of 1994, HR 4306, 103d Cong 2d Sess (Apr 28,1993) (proposing a comprehensive risk assesment program within the EPA). The Risk Assessment Improvement Act never came up for a vote, but portions of it, including those dealing with risk tradeoffs, were appended to the Environmental Technologies Act, HR 3870, 103d Cong 2d Sess (Feb 22, 1993).

126 The legislative centerpiece of the platform was the Risk Assessment and Cost-Benefit Act of 1995, HR 1022, 104th Cong, 1st Sess (Feb 23, 1995), led by Thomas Bliley (R-Va), which passed the House 286 to 141. Fred Anderson, et al, Regulatory Improvement Legislation: Risk Assessment, Cost-Benefit Analysis, and Judicial Review, 11 Duke Envir L \& Pol F 89, 98 (2000). The proposed legislation would have superseded the "decisional criteria" in all existing health-andsafety regulations. Id.

127 A number of regulatory reform bills were proposed during these years. For a discussion, see Anderson, et al, 11 Duke Envir L \& Pol F at 96-101 (cited in note 126) (presenting in chronological order and analyzing legislative initiatives to effect regulatory reform). The most significant pieces of proposed legislation included the Comprehensive Regulatory Act of 1995, S 343, 104th Cong, 1st Sess (Feb 2, 1995); the Risk Assessment and Cost-Benefit Act of 1995, HR 1022, 104th Cong, 1st Sess (Feb 23, 1995); the Regulatory Improvement Act of 1998, S 981, 105th Cong, 2d Sess (June 27, 1997); the Regulatory Improvement Act of 1999, S 746, 106th Cong, 1st Sess (Mar 25, 1999); and the Regulatory Improvement Act of 2000, HR 3311, 
have dropped from the congressional agenda, ${ }^{125}$ there is no reason to believe that concern about these issues has gone away, only that the political conditions for the passage of broad-gauged regulatory reform bills are not necessarily present.

In addition to general statutory language calling for risk assessment of regulatory proposals, each of these bills also featured specific provisions requiring agencies to consider risk tradeoffs, or in the words of the bills, "substitution risks," which might be brought about by major regulatory interventions. ${ }^{130}$ The nature of the requirement to consider "substitution risks" differs very little from one bill to another. ${ }^{131}$ There is one important difference, however, in the manner in which the various bills define "substitution risk." All except one follow the example of the first comprehensive regulatory reform bill, which defines "substitution risk" as "a potential risk to human health, safety, or the environment from a regulatory alternative designed to decrease other risks." ${ }^{132}$ The one outlying bill is the Regulatory Improvement Act of 1999, which defines substitution risk as "a reasonably identifiable significant increased risk to health, safety, or the environment expected to result from a regulatory option; and [that does] not include risks attributable to the effect of an option on the income of individu-

106th Cong, 1st Sess (Nov 10, 1999).

128 A keyword search in the Lexis-Nexis Congressional Universe turned up seventeen different bills from the 104th Congress that mentioned "substitution risks," and only one from the 107th Congress (conducted Feb 16, 2002).

129 See Sunstein, 48 Stan L Rev at 249-51 (cited in note 8) (referring to the ambitious regulatory reform bills of the 104th Congress as part of a "Stalled Constitutional Moment"). See also Richard L. Revesz, Federalism and Environmental Regulation: A Public Choice Analysis, 115 Harv L Rev 553, 635 (2001) (citing the political dynamics of the 1990s as a reason for the lack of federal environmental regulation).

130 Interest in substitution risks has not been limited to these broad-gauged regulatory reform initiatives. The requirement to consider substitution risks has also appeared in various bills that focus on the assessment of risk at so-called defense nuclear facilities. See, for example, HR 1649, § 513(b)(3)(D), 106th Cong, 1st Sess (Apr 29, 1999) (mandating that site-specific risk assessments of nuclear facilities provide "a statement of any significant substitution risks to human health").

131 See HR 3311, \$§ 621 (7)(C)(ii), 622(a)(1)(A), 106th Cong, 1st Sess (Nov 10, 1999) (requiring that any health, safety, or environmental regulation be accompanied by a risk assessment of, inter alia, "an evaluation of any substitution risk relating to the proposed rule"); S 746, § 621(11), 106th Cong, 1st Sess (Mar 25, 1999) (defining substitution risks as a "reasonably identifiable significant risk to health, safety, or the environment expected to result from a regulatory option"); S 981, \& 624(h), 105th Cong, 2d Sess (June 27, 1997) (cited in note 10) ("When scientifically appropriate information on significant substitution risks to health, safety, or the environment is reasonably available to the agency, the agency shall describe such risks in the risk assessment."); HR 1022, § 105(4), 104th Cong, 1st Sess (Feb 23, 1995) ("Each significant risk assessment or risk characterization document shall include a statement of any significant substitution risks to human health, where information on such risks has been provided to the agency."); S 343, § 636(2), 104th Cong, 1st Sess (Feb 2, 1995) (requiring that an agency risk assessment "include a statement of any significant substitution risks, when info on such risks has been made available to the agency").

132 HR 9, § 420(4), 104th Cong, 1st Sess (Jan 4,1995). 
als." ${ }^{133}$ This definition explicitly excludes so-called health-health tradeoffs. ${ }^{134}$

While none of these comprehensive legislative initiatives has become law, some bills containing language about risk tradeoffs have. One example is the "clean fuels" provisions in the Clean Air Act, enacted in 1990, which require the EPA to report on "any negative health or environmental consequences to the community of efforts to reduce such risks." ${ }^{135}$ Similarly, the 1996 Amendments to the Safe Drinking Water Act mandate the analysis of "[a]ny increased health risk that may occur as the result of compliance, including risks associated with co-occurring contaminates." ${ }^{136}$ These statutory initiatives may be indicative of a growing interest on Capitol Hill in the risk tradeoff phenomenon.

\section{2. $\mathrm{OMB}$ and the administrative agencies.}

In conducting cost-benefit analyses of regulation pursuant to Executive Orders 12291 and 12866, OMB has, at least at times, relied on risk tradeoff analysis-especially health-health tradeoff analysis. ${ }^{137}$ The best known example is the "return letter" that James B. MacRae, Acting Administrator of OIRA, sent to Nancy Risque-Rohrbach, Assistant Secretary for Policy in the Department of Labor, on March 10, $1992 .{ }^{138}$ In that letter, OMB, citing recent studies on health-health tradeoffs, ${ }^{139}$ as well as the then newly minted opinion by Judge Williams in Lockout/Tagout, suspended its review of an OSHA proposed rule pending OSHA's consideration of the health-health implications of setting permissible exposure levels ("PELs") for more than six hundred workplace air contaminants. ${ }^{140}$ As MacRae reasoned in the letter: "If government regulations force firms out of business or into

133 S 746, § 621(11)(A)-(B), 106th Cong, 1st Sess (Mar 25, 1999).

134 It may be that this bill reflects the influence of Graham and Wiener, who oppose the inclusion of health-health tradeoffs under the rubric of risk tradeoff analysis. See note 36 .

13542 USC $\S 7412(f)(1)(C)$ (1994). See also Sunstein, 63 U Chi L Rev at 1568 (cited in note 3) (referring to the provisions as a "modest forerunner" of more dramatic changes).

13642 USC \$ 300g-1(b)(3)(C)(i)(VI) (1994). See also David W. Schnare, Environmental Rationality and Judicial Review: When Benefits Justify Costs under the Safe Drinking Water Act Amendments of 1996, 5 Hastings W-Nw J Envir L \& Pol 65, 90-91 (1998) (discussing amendments).

137 See Lutter and Morrall, $8 \mathrm{~J}$ Risk \& Uncertainty at $45-46$ (cited in note 37) (discussing an example of OMB's application of health-health analysis).

138 The letter was read in its entirety into the Congressional Record. See Regulatory Review Process, 138 Cong Rec S 3806-03, 3808-09 (Mar 18, 1992).

139 See, for example, Keeney, 10 Risk Anal at 147 (cited in note 3) (arguing that regulators take health-health effects into consideration).

140 See OMB Interference in OSHA's Efforts to Protect Worker Health and Safety, 138 Cong Rec S 3858-01 (Mar 18, 1992) (discussing OSHA's suspension). 
overseas production, employment of American workers will be reduced, making workers less healthy by reducing their incomes."

The letter sparked a great deal of congressional interest. ${ }^{142}$ An outraged Senator Kennedy deplored OMB's use of "Alice in Wonderland economics." ${ }^{143}$ Senator Glenn, then Chairman of the Government Affairs Committee, called for an investigation into health-health tradeoffs by the General Accounting Office ("GAO"). ${ }^{14}$ The GAO investigation found that OIRA had improperly relied on health-health analysis as a means of circumventing the statutory ban on carrying out cost-benefit analysis, that the agency did not use the methodology correctly (from a technical standpoint), and that generally speaking the methodology was, in the words of Senator Glenn, "a pipe dream., ${ }^{145}$

In the face of intense congressional scrutiny, OMB backed down from its position on that occasion. ${ }^{146}$ But there is no indication that OMB has disavowed health-health analysis, ${ }^{147}$ and with John Graham as OIRA Administrator, OMB may rely more heavily on risk tradeoffs going forward than it does already. Given Justice Breyer's blessing of health-health analysis in his concurring opinion in American Trucking, ${ }^{143}$ it will be more difficult for a senator to refer to its application as "deregulation policy run amok.",

Despite the growing interest in risk tradeoff analysis in the executive, legislative, and judicial branches, the agencies themselves have not pursued the methodology with noticeable vigor. ${ }^{1.0}$ Graham and

141 Regulatory Review Process, 138 Cong Rec at S 3809 (cited in note 138).

142 The incident was widely reported in the media at the time. See, for example, Adam Clyner, Budget Office Retreats on Work Health, NY Times A8 (Mar 30, 1992) (reporting the MacRae incident); Bob Davis and Albert R. Karr, Bush to Require Regulators to Weigh Costs and Impact on Health, Mortality, Wall St J A3 (Mar 20, 1992) (same); Frank Swoboda, OMB's Logic: Less Protection Saves Lives, Wash Post A15 (Mar 17, 1992) (same); Robert D. Hershey, Jr., Cutting Costs, Budget Office Blocks Workplace Health Proposal, NY Times A13 (Mar 16, 1992) (same).

143 OMB Interference, 138 Cong Rec at S 3858-01 (cited in note 140).

144 See OMB Risk/Risk Analysis, 138 Cong Rec S 10957-01 (July 30,1992).

145 Id.

146 See id (Sen Glenn) ("Within a few days of the hearing, OMB backed down and allowed the OSHA rulemaking to go forward.").

147 In a recent speech, John F. Morrall III, who as an OIRA staff economist was responsible (together with Randall Lutter) for the health-health analysis behind the OSHA return letter, and who now serves in a senior staff position at OIRA, acknowledged that the media criticism of the return letter was disappointing, but that the story of health-health analysis "had a happy ending" because of the methodology's subsequent rise to prominence in regulatory debate. See John F. Morrall III, Chief, Human Resources and Housing Branch, Office of Information and Regulatory Affairs, Office of Management and Budget, Ebbs and Flows in the Quality of Regulatory Analysis $* 7$ (Dec 17, 2001) (speech at conference on executive regulatory review), available online at <http://wc.wustl.edu/regreviewvideo.html $>$ (visited Apr 19,2002).

148 See text accompanying notes $157-61$.

149 OMB Interference, 138 Cong Rec at S 3858-01 (Sen Kennedy) (cited in note 140).

150 Industry groups have called on agencies to implement risk tradeoff analysis. See, for example, Michael J. Whinihan, Senior Economist, General Motors Public Policy Center, Statement at the Public Advisory Committee Meeting before the Environmental Economics Advisory 
Wiener indicate that the number of such analyses carried out in the agencies is "probably quite small.", They do, however, point to some isolated examples. For instance, the EPA released a study showing that under certain circumstances, using electric vehicles as a means of reducing air pollution might actually bring about more air pollution, depending upon how and where the electricity was generated. ${ }^{1.2}$

\section{Courts: Justice Breyer's concurrence in American Trucking.}

The Supreme Court in American Trucking ${ }^{153}$ unanimously rejected the nondelegation challenge to the EPA's regulations that had carried the day in the D.C. Circuit and reaffirmed that the Clean Air Act prohibits the consideration of costs in setting NAAQS. ${ }^{144}$ Writing separately, Justice Breyer agreed with the result in the case but explained that he favored a general presumption that Congress requires the consideration of costs in regulatory statutes. ${ }^{135}$ Justice Breyer argued that the legislative history and structure of the Clean Air Act made clear, however, that "§ 109's language reflects a congressional decision not to delegate to the agency the legal authority to consider economic costs of compliance.,116

In particular, Justice Breyer indicated that to foreclose completely the consideration of costs would be to "require the EPA to eliminate every health risk, however slight, at any economic cost,

Committee of the EPA Science Advisory Board (Nov 30,2001) (advocating risk tradeoff analysis and relying on a $\$ 7$ million per statistical life valuation as the benchmark for EPA health-health tradeoff analysis) (on file with authors).

151 Wiener and Graham, Resolving Risk Tradeoffs at 252 (cited in note 34).

152 Id, citing Oscar Suris, Electric Cars Pollute Air, EPA Study Says, Wall St J B1 (Apr 5, 1994). See Office of Transportation and Air Quality, EPA, Electric Vehicles, Fact Sheet No OMS10 (1994), available online at <http://www.epa.gov/otaq/10-elec.htm> (visited Apr 21, 2002) (drawing attention to the "pollution tradeoff").

153531 US at 472-76. Professor Revesz served as counsel of record for amici Environmental Defense, et al, before the Supreme Court in American Trucking. See Brief of Amici Curiae Environmental Defense, et al, on behalf of Petitioners, Browner v American Trucking Associations, $I n c$, No 99-1257 (filed July 21, 2000), available on LEXIS at 1999 US Briefs 1257 and Brief of Amici Curiae Environmental Defense, et al, on behalf of cross-respondents, American Trucking Associations, Inc v Browner, No 99-1246 (filed September 11,2000), available on LEXIS at 1999 US Briefs 1426. His briefs, however, did not deal with the risk tradeoff issues that are the subject of this Article.

154 See 531 US at 464-71,481-87. The Court declined the industry group's invitation to infer a requirement to take costs into account from the statute's requirement to set NAAQS at a level "requisite to protect the public health" with "an adequate margin of safety." See id, quoting 42 USC $\$ 7409$ (b)(1) (emphasis added). The Court reasoned that absent clear statutory language to the contrary, it would be far-fetched to assume that "Congress would give to the EPA through these modest words the power to determine whether implementation costs should moderate national air quality standards." 531 US at 468.

155531 US at 490 (Breyer concurring in part and concurring in the judgment).

156 Id. 
however great, to the point of 'hurtling' industry over 'the brink of ruin,' or even forcing 'deindustrialization." "' He stated:

The statute also permits the Administrator to take account of comparative health risks. That is to say, she may consider whether a proposed rule promotes safety overall. A rule likely to cause more harm to health than it prevents is not a rule that is "requisite to protect the public health." For example, as the Court of Appeals held and the parties do not contest, the Administrator has the authority to determine to what extent possible health risks stemming from reductions in tropospheric ozone (which, it is claimed, helps prevent cataracts and skin cancer) should be taken into account in setting the ambient air quality standard for ozone. $^{1 \mathrm{ss}}$

Thus, Justice Breyer invoked Judge Williams's analysis based on direct risk tradeoffs to illustrate why, even without permitting the consideration of costs, the statute does not inevitably require maximally stringent regulation. He then drew on risk tradeoff analysis to provide a limiting principle-a technique to discipline agency decisionmakers different from cost-benefit analysis. If a regulation were to entail an intolerably profound risk tradeoff, it could be rejected.

A few paragraphs later, Justice Breyer again invoked risk tradeoff analysis, this time in the language of health-health tradeoffs: "Nor need regulation lead to deindustrialization. Preindustrial society was not a very healthy society; hence a standard demanding the return of the Stone Age would not prove 'requisite to protect the public health." "159 Since excessively expensive regulation not only violates canons of cost-benefit analysis but also reduces overall health, he argued, it violates the statutory requirement to promote public health.

Justice Breyer's concurrence marks the arrival of risk tradeoff analysis in general, and health-health tradeoff analysis in particular, in the Supreme Court. It can be expected to pave the way for future challenges based on risk tradeoffs. The opinion is also noteworthy for at least two other reasons. First, Justice Breyer drew attention to the manner in which risk tradeoff analysis, and in particular health-health tradeoff analysis, can serve as a proxy for cost-benefit analysis when it is prohibited by statute. Commentators have observed that risk tradeoff analysis emerged in part because of statutory limitations on the application of cost-benefit analysis. ${ }^{160}$ But because health-health analysis can, to some extent, serve as a functional substitute for cost-benefit

157 Id at 494.

158 Id at 495.

159 Id at 496.

160 See text accompanying notes 183-86. 
analysis, one might argue that it should be prohibited whenever costbenefit analysis is prohibited. ${ }^{161}$ Justice Breyer, while recognizing the utility of health-health tradeoffs functionally to accomplish what costbenefit analysis would have done had its use been permitted, took the position that the methodologies are sufficiently different that the ban on one does not apply to the other.

The Keeney estimate on which many health-health analyses rely (\$14.7 million in 1999 dollars), ${ }^{162}$ differs significantly from the valuation of an individual life on which the EPA relies for purposes of costbenefit analyses ( $\$ 6.0$ million in 1999 dollars). ${ }^{163}$ Thus, practically speaking, regulations that would be prohibited as violations of costbenefit principles might well be upheld under health-health analysis. But if lower values are used in health-health analysis, as industry groups urge, ${ }^{164}$ the two methodologies are essentially equivalent.

Second, Justice Breyer implicitly equated health-health tradeoffs with other risk tradeoffs. He relied on Judge Williams's direct risk tradeoff analysis to ground his own claim about health-health tradeoffs. To Justice Breyer, both a regulation that entails a significant direct risk tradeoff and one whose exorbitant cost brings about health risks appear to be instances of a "[rule] likely to cause more harm to health than it prevents" and so "not a rule that is "requisite to protect the public health."'165 Thus, he implicitly rejected the approach of some leading commentators, who deny the conceptual similarity among the various types of tradeoffs. ${ }^{166}$

\section{RISK TRADEOFF ANALYSIS AND INATTENTION TO ANCILLARY BENEFITS}

As we have seen, regulatory interventions have complex and unforeseen consequences that extend beyond the particular risks at

161 The General Accounting Office, responding to a request by Senator John Glenn, investigated the relationship between health-health tradeoff analysis and cost-benefit analysis and concluded, in the words of the Senator, that health-health analysis, "no matter what it is called, involved balancing benefits ... against compliance costs." OMB Risk, 138 Cong Rec at $\$ 10957-01$ (cited in note 144). See also text accompanying notes $42-49$.

162 See text accompanying notes 87-91.

163 The EPA established that figure at $\$ 5.8$ million in 1997 dollars, which is equivalent to $\$ 6.0$ million in 1999 dollars. See EPA, Guidelines for Preparing Economic Analyses 90 (2000), available online at <http://yosemite1.epa.gov/ee/epa/eed.nsf/pages/guidelines\#download> (visited Apr 25, 2002). Professor Revesz serves on the Environmental Economics Advisory Committee ("EEAC") of the EPA's Science Advisory Board. The EEAC reviewed the EPA Guidelines.

164 See note 150.

165 American Trucking, 531 US at 495.

166 See, for example, Graham and Wiener, Confronting Risk Tradeoffs at 20 (cited in note 2) (distinguishing their approach from health-health analysis). See also note 36. But see Lutter and Morrall, $8 \mathrm{~J}$ Risk \& Uncertainty at 46 (cited in note 37) (contending that health-health analysis is a form of risk-risk analysis). 
which they are directed. Sometimes these side effects will be negative. Identifying and quantifying these negative side effects, or ancillary risks, is the central objective of risk tradeoff analysis. ${ }^{167}$ Other times, they will be positive-that is, there will be what we refer to as ancillary benefits. ${ }^{108}$ Part III.A establishes that leading academic and judicial applications of risk tradeoff analysis almost without exception ignore ancillary benefits. ${ }^{169}$ It also presents a historical explanation as to why the methodology developed the way it did. The inattention to an important category of consequences of a regulatory intervention makes risk tradeoff analysis an incomplete methodology for the evaluation of regulatory policy.

The inattention to ancillary benefits that is characteristic of risk tradeoff analysis might be justified, at least in part, if ancillary benefits were, as an empirical matter, less prevalent than risk tradeoffs. Graham and Wiener advance such a claim, drawing on public choice theory. ${ }^{170}$ In Part III.B, we refute this claim and show that as a logical matter, regulatory interventions are no less likely to produce ancillary benefits than risk tradeoffs.

In Part III.C, we extend the typology of risk tradeoffs set out in Part I to ancillary benefits, with an eye to illustrating their prevalence. We provide examples of direct ancillary benefits, as well as ancillary benefits brought about by substitution effects and health-health effects. We also suggest that there may be positive counterparts to health-health tradeoffs and lulling effects, and raise some analytical concerns with the relevant academic literatures.

\section{A. Inattention to Ancillary Benefits}

Advocates of risk tradeoff analysis, while aspiring to a more "holistic" approach to regulation, consistently ignore the possibility that regulatory interventions will produce ancillary benefits and not merely ancillary harms. ${ }^{121}$ This systematic inattention to ancillary bene-

167 See Graham and Wiener, Confronting Risk Tradeoffs at 19 (cited in note 2) ("In [risk tradeoff analysis], the challenge is to consider and assess explicitly the impacts of interventions on important countervailing risks as well as on the target risk.").

168 Keeney and von Winterfeldt have written that "an analysis and evaluation of regulatory options should identify and trade off all the effects of the alternatives, including the direct health benefits and costs, indirect health benefits and risks, as well as higher order costs, risks, and benefits." 16 Interfaces at 25 (cited in note 35) (emphasis added).

169 The term "ancillary benefits" appears to have been coined by Burtraw and Toman. See Dallas Burtraw and Michael Toman, The Benefits of Reduced Air Pollutants in the U.S. from Greenhouse Gas Mitigation Policies, Discussion Paper No 98-01-REV at ii, 1 (Resources for the Future 1997), available online at <http://www.rfforg/CFDOCS/disc_papers/PDF_files/ 9801rev.pdf (visited Apr 21, 2002).

170 See Wiener and Graham, Resolving Risk Tradeoffs at 232-33 (cited in note 34).

171 See, for example, Wiener, 9 Risk at 82 (cited in note 35) (identifying a holistic approach with one that "[t]ake[s] countervailing risks seriously"). 
fits among students and practitioners of regulation leads to distortions in the evaluation of the risk portfolio of regulation. In this Part, we draw attention to the phenomenon of inattention to ancillary benefits and offer an explanation of how risk tradeoff analysis developed to exhibit this bias.

Inattention to ancillary benefits is a hallmark of the leading academic and judicial writing on risk tradeoff analysis. For example, Viscusi endorses the application of risk tradeoff analysis to the regulatory process, arguing that "regulatory agencies should be concerned with this broader effect of regulatory policy since their mandate is to improve the health and welfare of citizens generally." Bn "broader effect," Viscusi refers only to ancillary harms brought about by the regulation, not ancillary benefits. ${ }^{173}$ Sunstein also fails to address the possibility that regulation might have ancillary benefits. As he states it, "The problem occurs when the diminution of one health risk simultaneously increases another health risk.",174

Like the academic commentators, Judge Williams makes no reference to ancillary benefits in his opinions discussing risk tradeoffs. In American Trucking, for instance, he writes: "Legally, then, EPA must consider positive identifiable effects of a pollutant's presence in the ambient air in formulating air quality criteria under $\S 108$ [of the

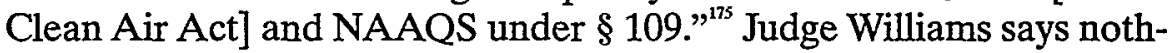
ing about the legal requirement to consider ancillary benefits, which presumably is no less compelling. Although Justice Breyer in his American Trucking concurrence maintains that under Section 109 of the Clean Air Act, the EPA Administrator "may consider whether a proposed rule promotes safety overall, ${ }^{, 176}$ he goes on to refer approvingly to Judge Williams's risk tradeoff analysis in the D.C. Circuit, and to put forward a health-health tradeoff argument of his own. He does not suggest that regulations might bring about ancillary benefits as well as harms.

Moreover, legislative initiatives to reform the regulatory process advocate risk tradeoff analysis, but are silent on ancillary benefits. ${ }^{1 m}$

172 Viscusi, 63 U Chi L Rev at 1455 (cited in note 9) (emphasis added).

173 See id. In another body of his scholarly output, Viscusi has discussed the ancillary environmental benefits that accrue from various $\mathrm{CO}_{2}$ pricing schemes. See Roy Boyd, Kerry Krutilla, and W. Kip Viscusi, Energy Taxation as a Policy Instrument to Reduce $\mathrm{CO}_{2}$ Emissions: $\mathrm{A}$ Net Benefit Analysis, 29 J Envir Econ \& Mgmt 1, 8-10 (1995); W. Kip Viscusi, et al, Environmentally Responsible Energy Pricing, 15 Energy J 23,31-41 (Iss 2 1994). Nevertheless, he does not consider those types of ancillary benefits in his discussions of risk tradeoffs.

174 Sunstein, 63 U Chi L Rev at 1535 (cited in note 3). In Sunstein's presentation of the problem - and the methodology - ancillary benefits are absent.

$175175 \mathrm{FBd}$ at 1052.

176531 US at 495 (Breyer concurring in part and concurring in the judgment).

177 See Part II.B.1. 
Similarly, while OIRA has called attention to ancillary harms, ${ }^{17 s}$ it has not evinced any interest in ancillary benefits.

Since regulatory interventions bring about a range of ancillary effects, positive as well as negative, we regard the systematic inattention to ancillary benefits as a serious methodological bias. Risk tradeoffs and ancillary benefits are simply mirror images of each other. There is no justification for privileging the former and ignoring the latter.

What accounts for this unwarranted asymmetry? At one level, the answer is simple: Risk tradeoff analysis fails to take notice of ancillary benefits because it fails to look for them in the first place. Since risk tradeoff analysis searches only for countervailing risks, it finds only countervailing risks. But this explanation merely invites a second question: Why does the methodology not look more broadly at all the effects of a regulatory intervention?

We suggest a path-dependent account. Risk tradeoff analysis began as a tool of deregulation. Once it became established, it gained support across the political spectrum. This result is not surprising, given that the limitations of risk tradeoff analysis have not been widely discussed in either the academic community or the policy community.

The emergence and ascendancy of risk tradeoff analysis is closely linked to the rise of cost-benefit analysis during two antiregulatory "moments" in recent American political history: President Reagan's election in 1980, and the 1994 legislative elections that, for the first time in years, produced Republican majorities in both houses. ${ }^{179}$ The Reagan Administration ushered in the rise of cost-benefit analysis as an overarching metric to provide coherence and rationality to the administrative state. ${ }^{180}$ The Contract with America meanwhile ushered in what Sunstein has referred to as the "Cost-Benefit State."181 Comprehensive regulatory reform initially proposed in 1994 would have required the implementation of cost-benefit analysis and risk tradeoff

178 See text accompanying notes $137-41$.

179 The contention that intervention in the economy and society is liable to bring about unforeseen risks is, in its broadest articulation, a hallmark of the kind of the conservative political theory associated with Edmund Burke. See, for example, Albert O. Hirschman, The Rhetoric of Reaction: Perversity, Futility, Jeopardy 12-13 (1991) (illustrating by reference to Burke a type of reactionary rhetoric marked by a tendency to identify the perverse results of reforms); Anthony T. Kronman, Precedent and Tradition, 99 Yale L J 1029, 1056 (1990) (presenting the Burkean view that even the most pressing social reforms ought to be undertaken "in a spirit of 'infinite caution"'); Michael Oakeshott, Rationalism in Politics, in Michael Joseph Oakeshott, Rationalism in Politics: And Other Essays 1,31 (Basic Books 1962) ("[T]he Rationalist is a dangerous and expensive character to have in control of affairs, and he does most damage ... when he appears to be successful.").

180 See, for example, Exec Order 12291, 3 CFR $\$ 127$ (1981) (making new regulations subject to cost-benefit analysis except where prohibited by statute). See also note 26 .

181 Sunstein, 48 Stan L Rev at 249 (cited in note 8). 
analysis across all health-and-safety regulation. As discussed above, even though the general bills did not pass, the administrative state has been moving in that direction in smaller steps. ${ }^{10}$

In light of the rise to prominence of cost-benefit analysis, risk tradeoff analysis has two important antiregulatory purposes. First, it functions as a proxy for cost-benefit analysis when the latter is prohibited by law. ${ }^{133}$ In an important case decided just before Reagan became president, the D.C. Circuit held that Section 109 of the Clean Air Act expressly forbids the EPA from considering the costs of the NAAQS. ${ }^{184}$ Against the backdrop of that and similar rulings, Viscusi and Richard Zeckhauser argue that risk tradeoff analysis is especially necessary when governing law prevents decisionmakers from employing costbenefit analysis. ${ }^{185}$ In particular, health-health tradeoff analysis became important as a means of circumventing statutory prohibitions on costbenefit analysis. ${ }^{186}$ Like cost-benefit analysis, health-health analysis requires a comprehensive understanding of the costs of regulation in order to analyze whether it promotes health on balance-just the type of inquiry the statute would otherwise prohibit.

When statutes do not preclude the application of cost-benefit analysis, risk tradeoff analysis reduces the benefits that would otherwise be imputed to regulation (or adds to its costs). This use of risk tradeoff analysis is perhaps best seen in the comprehensive statutory initiatives associated with the Contract with America, in which risk tradeoff analysis came to play an increasingly prominent role not as a partial proxy for cost-benefit analysis, but as a significant tool in its own right.

In summary, risk tradeoff analysis was developed and took shape at two crucial moments of heightened antiregulatory sentiment. This conservative pedigree of risk tradeoff analysis is responsible for its incompleteness. Indeed, Viscusi has directly addressed the question of whether risk tradeoff analysis is tethered to any particular ideological commitment about the regulatory state:

A final objection that might be raised against these various riskrisk approaches is political. Some critics have suggested that the

182 See text accompanying notes 135-36.

183 See text accompanying notes $162-64$.

184 Lead Industries Association, Inc v EPA, 647 F2d 1130,1148 (DC Cir 1980). The Supreme Court recently reaffirmed that case in American Trucking, 531 US at 464-71.

185 W. Kip Viscusi and Richard J. Zeckhauser, The Fatality and Injury Costs of Expenditures, 8 J Risk \& Uncertainty 19, 21 (1994).

186 See text accompanying notes 162-64 (discussing divergence of the two methodologies). See also Paul R. Portney and Robert N. Stavins, Regulatory Review of Environmental Policy: The Potential Role of Health-Health Analysis, $8 \mathrm{~J}$ Risk \& Uncertainty 111, 118 (1994) (observing that health-health analysis emerged in part because of "statutory constraints limiting the use of cost information in setting standards"). 
reason such approaches have been embraced is that policymakers are simply seeking a political mechanism to limit environmental regulations. Imposing limits is not [necessarily] undesirable, however. The task of regulatory oversight is to ensure that the risk regulations being issued are in society's best interest. ${ }^{157}$

Because of path dependency, once risk tradeoff analysis became established-prodded in large part by Professors Graham and Viscusi-it retained its methodological bias against the consideration of ancillary benefits that was an outgrowth of its antiregulatory pedigree. That bias persists today, even as risk tradeoff analysis is invoked by academics and judges across a broad range of the ideological spectrum, including Professor Sunstein and Justice Breyer, and is explicitly regarded by some of its staunchest supporters as a means of achieving more efficient, though not necessarily less, regulation. ${ }^{158}$

\section{B. Challenging the Claim That Ancillary Benefits Are}

Less Prevalent

Graham and Wiener are the only champions of risk tradeoff analysis who consider the possibility that regulatory interventions will produce ancillary benefits as well as harms. "There can also be "coincident risk reductions," they write, "unintended bonuses of efforts to reduce a target risk." choice theory, that "coincident risk reductions [what we refer to as "ancillary benefits"] are less likely to be prevalent than are countervailing risks.",

There are three interrelated steps to Graham and Wiener's argument that ancillary benefits will be relatively rare. First, they put forward a general argument about why public choice pathologies give rise to risk tradeoffs. Next, they argue that systematic forces do not similarly bring about ancillary benefits. Finally, they claim that decisionmakers can be expected to excise such benefits should they nevertheless arise. We address and criticize their arguments at each of these three stages.

1. Public choice and tradeoffs.

Graham and Wiener draw on public choice theory to explain that regulatory interventions produce risk tradeoffs as a result of omitted

187 Viscusi, $8 \mathrm{~J}$ Risk \& Uncertainty at 15 (cited in note 114).

$18 s$ See, for example, Wiener, 9 Risk at 81 (cited in note 35) (arguing that risk tradeoff analysis is a tool for more effective regulation, rather than a tool for deregulation).

i89 Graham and Wiener, Confronting Risk Tradeoffs at 37 (cited in note 2).

190 Wiener and Graham, Resolving Risk Tradeoffs at 232 (cited in note 34). 
voice. $^{191}$ Consistent with standard public choice accounts, ${ }^{192}$ they maintain that regulatory decisions will often have a concentrated impact on certain groups. These groups will have a strong incentive to make their voices heard in the regulatory process. By contrast, the incentives for ordinary citizens will be smaller, commensurate with the relatively less concentrated impact the regulation will have on them. Because of these disparate incentives, the interest groups will play a prominent role in the regulatory process, while the majority of citizens will not. Consequently, when a highly affected interest group approaches a regulatory decisionmaker with a proposal that has the consequence of transferring risk from that group to a broader population, the "decisionmaker is unlikely to take account of countervailing losses imposed on constituencies who are not participating in the dialogue [of regulatory policymaking].",193

In theory, the decisionmaker could invest time and effort to discover a means to remove the target risk from the interest group without passing it (or another risk) on to the unsuspecting population. But because the broader population does not participate in the regulatory process, the decisionmaker is willing to ignore the risk tradeoff of her decision. ${ }^{194}$ Thus, public choice pathologies give rise to risk tradeoffs when policymakers redistribute risk away from well-organized groups and onto poorly organized populations.

We begin by calling attention to limitations in this account. Graham and Wiener do not provide a general argument for why ancillary benefits will be less prevalent than ancillary harms. Rather their account depends upon the risk tradeoffs' possessing a certain pedigree (omitted voice) and a certain defining characteristic (redistributing risk away from one group and onto another). Omitted voice, however, as Graham and Wiener acknowledge, is only one source of risk tradeoffs among many. The authors discuss a number of other reasons for risk tradeoffs, ranging from the cognitive limitations of decisionmakers to problems of bureaucratic organization. ${ }^{195}$ Thus, Graham and

191 See id at 230-33. Consistent with their general view that health-health tradeoffs should not be considered under the banner of risk tradeoff analysis, Graham and Wiener's public choice argument does not apply to health-health tradeoffs.

192 For a general discussion, see Sam Peltzman, Toward a More General Theory of Regulation, 19 J L \& Econ 211 (1976) (developing the idea that regulatory agencies do not exclusively serve a single economic interest); George J. Stigler, The Theory of Economic Regulation, 2 Bell J Econ \& Mgmt 3, 3 (1971) ("The potential uses of public resources and powers to improve the economic status of groups (such as industries and occupations) are analyzed to provide a scheme of the demand for regulation.").

193 Wiener and Graham, Resolving Risk Tradeoffs at 230 (cited in note 34).

194 See id.

195 The authors refer to "heuristics," "bounded oversight roles," and "behavioral responses" as other causes of risk tradeoffs. See Wiener and Graham, Resolving Risk Tradeoffs at 233-42 (cited in note 34). 
Wiener at best can explain the supposed dearth of ancillary benefits with respect to those risk tradeoffs that come about because of public choice pathologies.

Similarly, Graham and Wiener's argument can at most explain why ancillary benefits are less likely to be prevalent when the tradeoff takes the form of a risk redistribution. ${ }^{196}$ Risk redistributions come about when a regulatory intervention brings about an ancillary harm that affects a population distinct from the population affected by the original risk. There are two kinds of such redistributions. When the risk itself is identical to the original risk, Graham and Wiener speak of a "risk transfer." Thus, adopting a policy to recycle lead batteries may merely redistribute the risk of lead poisoning to the population of workers and citizens living near a lead smelter. ${ }^{198}$ The authors use the term "risk transformation" to describe what happens when both the nature of the risk and the affected population are changed. ${ }^{159}$ For instance, tightening fuel economy standards brings about a risk transformation when, in the name of reducing risks of toxicity, it redistributes a different risk (less safe cars) to a different population (drivers, passengers, and pedestrians). ${ }^{200}$

All of the risk tradeoffs that come about because of omitted voice problems will be risk redistributions of one kind or the other, because interest groups would be unlikely to seek to remove one risk to which they are exposed only to replace it with another such risk. But-and this is the nub-risk redistributions represent only two of the four categories of risk tradeoffs that Graham and Wiener identify." Thus, Graham and Wiener can at best explain why, within a small subset of risk tradeoffs, ancillary benefits are less likely to be prevalent than ancillary harms.

In addition to these significant limitations, the argument is flawed in a number of important ways. Graham and Wiener's omitted voice rationale for the existence of risk tradeoffs depends upon a certain conception of how regulation operates. Crucial to their story is the image of an interest group inclined to redistribute risks away from it-

196 See note 34.

197 Graham and Wiener, Confronting Risk Tradeoffs at 22-25 (cited in note 2).

198 See Katherine Walker and Jonathan Baert Wiener, Recycling Lead, in Graham and Wiener, eds, Risk versus Risk 149, 152 (cited in note 2) ("Secondary lead smelting, a key component of the recycling process, releases lead to ambient and workplace air, resulting in community and worker exposures to lead.").

199 Graham and Wiener, Confronting Risk Tradeoffs at 22-25 (cited in note 2) ("[W]hen the countervailing risk is different in both outcome and affected population, we describe the situation as a risk transformation.").

200 As an empirical matter, that population may overlap significantly with the population of "breathers" affected by automobile emissions. Analytically, however, the two populations are distinct.

201 See Graham and Wiener, Confronting Risk Tradeoffs at 22-25 (cited in note 2). 
self and onto unsuspecting "forgotten groups." There are two implicit assumptions in this image that are open to question. First, Graham and Wiener assume that a single interest group will capture the regulatory process and successfully impose its views on the captured agency. ${ }^{20}$ In practice, regulatory decisions are typically contested, with groups representing opposing views (paradigmatically public interest groups on the one hand and industry groups on the other) jockeying for superiority with the relevant decisionmaker ${ }^{203}$ In other words, the problem of the omitted voice is not as acute as the authors suggest.

A second, related problem in their account is the authors' failure to specify precisely which groups can be expected actively to seek regulation that redistributes risk away from them and onto others. Graham and Wiener suggest that the group might be "an industry or the raison d'etre of an advocacy group" ${ }^{204}$ but do not clarify, for instance, why an industry group would be seeking regulation in the first place, ${ }^{205}$ or why an advocacy group would be indifferent to, or supportive of, the imposition of health risks onto other populations. With respect to this latter point, Graham and Wiener assume that an advocacy group will have a singular mission: to advance a particular, limited agenda on behalf of a discrete population. But an advocacy group is just as likely to represent not a particular interest, but rather a range of interests, and for that matter, a range of populations. True, the American Lung Association might be less interested in skin cancers than respiratory disorders, and so might champion a regulation that transforms risk of respiratory disease into risk of melanoma, but the National Resources Defense Council ("NRDC"), for instance, is likely to care about a risk transfer away from conventional pollutants and toward global warming. That organization advocates reducing both

202 Graham and Wiener raise the possibility that multiple groups might mobilize to have their voices heard, but reason that legislators will still "tend to hear only part of the story" because they will be most responsive to the voices of their constituents. Wiener and Graham, $R e$ solving Risk Tradeoffs at 230 (cited in note 34).

203 See, for example, Toke S. Aidt, Political Internalization of Economic Externalities and Environmental Policy, 69 J Pub Econ 1, 1 (1998) (explaining that competition between lobby groups is an important source of internalization of economic externalities); Gary S. Becker, $A$ Theory of Competition among Pressure Groups for Political Influence, 98 Q J Econ 371, 372 (1983) (discussing competition among interest groups and the resulting equilibrium). Graham and Wiener recognize the phenomenon. Thus, in describing the potential risk tradeoffs of requiring senior citizens to be recertified for driver licenses, the authors note that the countervailing risks "may have been avoided because of the potent political voice of older people in this country." Wiener and Graham, Resolving Risk Tradeoffs at 231 (cited in note 34). The core of their argument, however, overlooks this possibility. See id at 230-33.

204 Wiener and Graham, Resolving Risk Tradeoffs at 230 (cited in note 34).

205 One example of an industry group that pursues regulation is the manufacturers of pollution control equipment. See Revesz, 115 Harv L Rev at 574 (cited in note 129). 
conventional pollutants and greenhouse gases, and is interested in the well-being of the respective populations affected by each. ${ }^{206}$

As an example of a risk tradeoff rooted in omitted voice, Graham and Wiener refer to a case study on the risks of dechlorination of drinking water. ${ }^{2 i 7}$ That case study draws attention to the risks of not chlorinating the drinking water supply (microbial disease) versus the risks of chlorinating (certain cancers). Although the authors of the study raise the possibility that dechlorination of the water supply will have a disproportionately significant effect on poor people who "would be less able to expend the necessary funds to switch to an alternative disinfection system or to purchase bottled water," ${ }^{203}$ they do not say which kinds of groups would advocate for redistributing risks away from themselves and onto others. Indeed, the authors of that study observe that "the federal EPA has begun negotiating rulemaking, involving industry as well as community leaders," ing an appropriate balance between the twin risks. Thus, far from showing how a single, self-interested group hijacks the regulatory process, the case study in fact shows how the regulatory process allows disparate groups to give voice to their interests.

\section{Interest groups and ancillary benefits.}

Graham and Wiener further argue that whereas powerful dynamics bring about ancillary risks, "there are no systematic forces at work to encourage such unexpected pluses [that is, ancillary benefits].,"210 Thus, they predict that ancillary benefits will be less prevalent than ancillary harms. Even if Graham and Wiener were correct about the general utility of the "omitted voice" rationale in explaining risk tradeoffs, their argument that incentives are not similarly structured to bring about ancillary benefits is unpersuasive.

Graham and Wiener suppose that interest groups will seek out regulatory intervention when they want to redistribute risk away from themselves and onto others. But they provide no reason to believe

206 Compare the Clean Air page on the NRDC website, available online at <http:// www.nrdc.org/air/default.asp> (visited Apr 19, 2002) ("No element of the natural world is more essential to life than air, and no environmental task more critical than keeping it clean."), with the Global Warming page, available online at <http://www.nrdc.org/globalWarming/ default.asp> (visited Apr 19, 2002) ("Global warming may be the most devastating environmental problem human beings have created.").

207 See Susan W. Putnam and Jonathan Baert Wiener, Seeking Safe Drinking Water, in Graham and Wiener, eds, Risk versus Risk 124, 124 (cited in note 2) (explaining how people have come to fear that adding chlorine to water may cause cancer, but chlorination of water is an important means of combating serious waterborne microbial diseases).

20 Id at 144.

209 Id at 145.

210 Id at 232 
that these interest groups would want to actively redistribute their risk, to reduce their own exposure only. The risk-minimizing proposals that the interest groups bring to the table are no more likely to bring about risk tradeoffs than ancillary benefits. If anything, there might be a selection bias under which interest groups advocate for target risk reductions with ancillary benefits rather than harms, on the theory that there would be less political or administrative resistance to such policies. ${ }^{211}$ The interest group lobbying for the target risk reduction would call attention to the ancillary benefits of the proposed regulation and enlist the beneficiaries of these coincident risk reductions in its attempt to win support for the regulation. This additional support could help defray the target group's advocacy costs and secure greater political capital for the decisionmaker.

\section{Incentives of decisionmakers.}

In addition to the claim that there are no underlying pressures to bring about ancillary benefits, Graham and Wiener reason that "[i]f decisionmakers foresaw opportunities to achieve coincident risk reductions, they would be likely to seek support from the beneficiary constituencies, or to try to pare their interventions to avoid providing uncompensated bonus reductions.".12 Thus, they argue that regulators would seek to eliminate ancillary benefits so as not to distribute freely rewards that are politically unearned.

Graham and Wiener assume that when an interest group proposes a regulation that entails risk tradeoffs, the decisionmaker will be unconcerned about these harms as long as the negatively affected group is ignorant or politically impotent. In contrast, according to Graham and Wiener, when an interest group proposes a regulation that has the ancillary effect of bringing benefits to others, the decisionmaker will choose to invest additional time and effort either to reduce or to remove the ancillary benefits or else to extract a price from the recipients of these benefits. There are two problems with this account. First, it will not always be technically feasible to remove the ancillary benefits. ${ }^{213}$ For example, a decisionmaker who agreed to set new stringent standards for sulfur dioxide (" $\mathrm{SO}_{2}$ ") emissions would

211 Occasionally, that resistance may be supplied by another agency, concerned with the potential negative implications of proposed regulations. Thus, the Department of Energy recently appears to have lobbied the EPA to relax pollution standards potentially burdensome to utilities. See, for example, Katharine Q. Seelye, EPA and Energy Department War over Clean Air Rules, NY Times A15 (Feb 19, 2002) (noting a fierce debate between the agencies pivoting on the impact of clean air regulations on the energy sector).

212 Wiener and Graham, Resolving Risk Tradeoffs at 232-33 (cited in note 34).

213 Recall that Graham and Wiener's argument applies only to ancillary effects that affect a population different from the population facing the target risk. If the ancillary benefits were to accrue to the same group, decisionmakers would have no incentive to pare them down. 
thereby bring about ancillary benefits in terms of greenhouse gas reductions. ${ }^{214}$ But it would be difficult to see how those benefits could be removed while preserving the original target risk reduction. Indeed, a significant body of literature on the phenomenon of free-riding begins with the assumption that it will not always be possible to restrict benefits to those who deserve them or have effectively paid for them. ${ }^{215}$

Even if a decisionmaker were able, as a technical matter, to pare down the ancillary benefits, what incentive would she have to do so? In the context of risk tradeoffs, Graham and Wiener argue plausibly that a decisionmaker will not expend time and effort to reduce ancillary harms to a "forgotten group" from which the decisionmaker can extract no political or financial capital. ${ }^{216}$ But to say that a decisionmaker has no incentive to confer "unearned" benefits is not to suggest-as Graham and Wiener seem to believe-that a decisionmaker has incentives to take time and expend energy to ensure that no one accidentally benefits from regulatory interventions. Depending on the magnitude of the ancillary benefits, the decisionmaker might indeed seek support from the benefited constituencies, as Graham and Wiener predict, ${ }^{217}$ but in doing so, she will first carefully weigh the costsincluding her opportunity costs-in expending time and resources in that way.

We have thus cast serious doubt on the only sustained account of why ancillary benefits will be less prevalent than risk tradeoffs. It is therefore unjustified to focus only on the latter, to the exclusion of the former.

\section{A Typology of Ancillary Benefits}

In Part I, we presented a typology of risk tradeoffs and supplied examples for each category. Consistent with our claim that ancillary benefits are properly thought of as the mirror image of risk tradeoffs, we now employ that typology to organize various kinds of ancillary benefits. Here, too, we provide examples of each type. We also point out substantial analytic limitations of health-health analysis, as well as of lulling effects. Our objective is to call attention to the prevalence of ancillary benefits, which have figured neither in academic debates about regulatory policy nor in regulatory practice, and to suggest a coherent approach to thinking about various types of ancillary bene-

214 See text accompanying notes 345-60.

215 See, for example, Mancur Olson, The Logic of Collective Action: Public Goods and the Theory of Groups 21 (Harvard 1971) (assuming that the benefits cannot be restricted).

216 Wiener and Graham, Resolving Risk Tradeoffs at 230 (cited in note 34) ("[W]here the consequences are broadly distributed across the general public, the incentives for ordinary citizens to organize and speak will be small.").

217 See id at 232-33. 
fits. At the same time, we cast doubt on the analytic soundness of two methodologies used to justify attention to risk tradeoffs in the regulatory process.

1. Direct ancillary benefits.

As we have seen, advocates of risk tradeoff analysis draw on analogies to iatrogenic injury and disease to explain the phenomenon of (direct) risk tradeoffs. ${ }^{218}$ Just as medical interventions designed to promote health frequently entail negative side effects, they argue, so too regulatory schemes intended to bring about greater overall health or safety may, in practice, accomplish the opposite. In so reasoning, these champions of risk tradeoff analysis systematically ignore the manner in which medical interventions-paradigmatically, drug therapies-carry with them not only negative, but also positive side effects. ${ }^{219}$ These positive side effects supply powerful examples of what might be thought of as direct ancillary benefits.

The medical literature is replete with studies showing that drugs originally approved or conventionally prescribed for certain purposes are in fact beneficial in treating unrelated conditions. ${ }^{20}$ Aspirin, to take a well-known example, was first introduced as an analgesic and antipyretic, but is now widely used also to reduce the risk of heart attack in susceptible individuals. ${ }^{221}$ It is even beneficial in reducing mortality after the onset of symptoms of a heart attack..$^{22}$ Recent evidence suggests that aspirin also reduces the incidence of colorectal cancer. ${ }^{22}$

Other examples abound. Estrogen therapy, originally introduced to combat the symptoms of menopause, significantly reduces osteoporosis and bone loss. ${ }^{24}$ Angiotensin Converting Enzyme ("ACE") in-

\footnotetext{
218 See Part I.A.

219 See, for example, Wiener, 9 Risk at 47-48 (cited in note 35) (discussing the frequency and severity of adverse drug events but ignoring ancillary benefits).

220 Because the FDA regulates substances, rather than the practice of medicine, drugs, once approved for certain purposes, may be prescribed by the medical community for "off-label" uses. See generally Laurence Landow, Off-Label Use of Approved Drugs, 116 Chest 589 (1999).

221 See Prevention: Aspirin Underused to Prevent Heart Attacks, Strokes, Heart Disease Weekly 8,9 (Feb 3,2002) (" $[\mathrm{A}]$ spirin is a life-saving treatment that will provide major benefits to many thousands of people at high risk of heart attack or stroke."); Jane E. Brody, Personal Health, NY Times C12 (Feb 23, 1994) (touting the benefits of aspirin for the prevention of heart

222 See Maryann Napoli, Aspirin Is Effective for Heart Attack, Health Facts 4, 4 (Dec 31, 1997) ("Taking an aspirin at the first sign of a heart attack has been judged to be a safe and effective means of reducing death and complications.").

223 See Jänne and Mayer, 342 New Eng J Med at 1961 (cited in note 23) (noting that "it is likely that aspirin ... act[s] as [a] chemopreventive agent] at early stages of carcinogenesis").

224 See Bente Riis, Karsten Thomsen, and Claus Christiansen, Does Calcium Supplementation Prevent Postmenopausal Bone Loss?: A Double-Blind, Controlled Clinical Study, 316 New Eng J Med 173, 176-77 (1987) (finding estrogen therapy more effective than calcium for retarding bone loss).
} disease). 
hibitors-developed as antihypertensive medicines-have been shown to prevent heart attacks, strokes, and the onset of diabetes in certain patients. ${ }^{2.5}$ Minoxidil, originally approved by the FDA as an antihypertensive, is now more commonly prescribed to prevent or reverse baldness. ${ }^{2 / 5}$ Botulinum toxin A (marketed as Botox) was recently approved for cosmetic use in smoothing wrinkles after it had been initially approved as a treatment for "eye spasms and other neurological disorders." 27

In the face of these and other examples of the direct ancillary benefits of medications, advocates of risk tradeoff analysis draw attention solely to their negative side effects. This one-sidedness is partially explained, perhaps, by distortions in the availability and timing of information related to positive side effects. The drug approval process places a premium on the discovery and disclosure of all significant adverse effects of a medication, but is not comparably concerned with the production of information concerning a drug's ancillary benefits. ${ }^{228}$ In addition, negative side effects might be more readily discernible than ancillary benefits. The tortuous career of the drug thalidomide is instructive in this regard. First produced in Germany in the 1950s, thalidomide was widely prescribed to pregnant women as an antiemetic. ${ }^{2 y}$ Reports of neuropathy associated with long-term use of the drug first surfaced in late 1960 . Soon a connection was made between the drug and the appearance of certain formerly rare birth defects. In 1961, thalidomide was withdrawn from world markets.

But in July 1998, thalidomide was approved by the FDA for treatment of erythema nodusom leprosum ("ENL"), an inflammatory complication of Hansen's disease. ${ }^{230}$ It has subsequently proved extremely effective against a broad range of dermatological disorders, as well as numerous HIV-related infections. ${ }^{231}$ Thus, a drug that forty years ago became (deservedly) notorious because of its negative side

225 See Mary Duenwald, Familiar Blood Pressure Drug Finds an Array of Novel Uses, NY Times F1 (June 25, 2002).

226 See Price, 341 New Eng J Med at 966 (cited in note 24).

227 Reed Abelson, F.D.A. Approves Allergan Drug for Fighting Wrinkles, NYTimes C4 (Apr 16,2002 ) (reporting the FDA's approval of Botox for cosmetic use).

228 See, for example, Laurence Landow, Roberta C. Kahn, and Curtis Wright, FDA's Role in Anesthetic Drug Development, 90 Anesthesiology 882, 883 (March 1999) (noting the requirement that the FDA be apprised within seven days of serious adverse drug events during clinical trials). Indeed, under the MedWatch reporting system, the FDA must be informed of adverse effects associated with drug administration even after approval. See id at 885.

229 Carrie L. Radomsky and Norman Levine, Thalidomide, 19 Dermatologic Clinics 87, 87 (Jan 2001).

230 L. Calabrese and A.B. Fleischer, Thalidomide: Current and Potential Clinical Applications, 108 Am J Med 487, 487 (2000) (reviewing recent insights and new therapeutic uses of Thalidomide).

231 Id. 
effects has proved to have significant direct ancillary benefits. Notwithstanding the potential disparities in the availability (or timing) of information about the negative and positive side effects of medication, there is no reason to believe that direct ancillary benefits are less prevalent than direct risk tradeoffs.

Nor are direct ancillary benefits confined to the medical context. They have been observed-or can be expected to be observed-across a broad cut of environmental and health-and-safety regulation as well. We offer some illustrative examples.

In the past few decades, constructed wetlands have emerged as an alternative to conventional wastewater treatment facilities as a means of complying with the Clean Water Act's effluent limits for wastewater discharge from point sources, including municipalities, industrial facilities, and animal feeding operations. ${ }^{2.2}$ Water treatment is a natural function of wetlands. ${ }^{233}$ Constructed wetlands can be used to manage wastewater, operating along the same principles as natural wetlands, creating a shallow basin filled with soil and vegetation through which water flows. ${ }^{24}$ As the water passes through, suspended particles settle; pollutants are broken down by plants, microorganisms, and sediment; nutrients are absorbed; and pathogens die off.

Worldwide, more than one thousand constructed wetland projects receive wastewater from municipal, industrial, and agricultural sources. ${ }^{236}$ Case studies of these projects, some of which have been operating for twenty years or more, demonstrate that constructed wetlands can function as low-cost, effective wastewater treatment systems. ${ }^{237}$ Constructed wetlands have also been observed to have generated noteworthy direct ancillary benefits.

232 See EPA, Office of Water, Constructed Wetlands for Wastewater Treatment and Wildlife Habitat, EPA832-R-93-005, Background (Sept 1993), available online at <http://www.epa.gov/ owow/wetlands/construc/backgrnd.html> (visited Oct 2, 2002).

233 EPA Office of Wetlands, Oceans, and Watersheds, Guiding Principles for Construction Treatment Wetlands: Providing for Water Quality and Wildlife Habitat, Part I: Introduction, (Oct 2000), available online at <http://www.epa.gov/owow/wetlands/constructed/guide.html> (visited Sept 3, 2002).

234 See EPA, Office of Wetlands, Oceans, and Watersheds, Design Manual: Constructed Wetlands and Aquatic Plant Systems for Municipal Waste Treatment 15 (Sept 1998), available online at <http://www.epa.gov/owow/wetlands/pdf/design.pdf $>$ (visited Sept 3, 2002) (providing an overview of the two types of constructed wetland treatment systems: free water surface system and subsurface flow system).

235 See EPA, Office of Wetlands, Oceans, and Watersheds, A Handbook of Constructed Wetlands 17 (Jan 1995), available online at <http://www.epa.gov/owow/wetlands/pdf/hand.pdf $>$ (visited Sept 3,2002).

236 Robert L. Knight, Wildlife Habitat and Public Use Benefits of Treatment Wetlands, 35 Water Sci \& Tech 35 (Iss 5 1997).

237 See EPA, Office of Wetlands, Oceans, and Watersheds, Constructed Wetlands for Wastewater Treatment and Wildlife Habitat, Free Water Surface Constructed Wetland Systems, available online at <http://www.epa.gov/owow/wetlands/construc/freewatr.html> (visited Sept 3,2002). 
Designed to replicate their natural counterparts, constructed wetlands produce many of the same benefits, including habitat creation and preservation, carbon sequestration, erosion control, and recreational and research opportunities. ${ }^{238}$ The creation of habitat for fauna and flora is perhaps the most significant ancillary benefit of the construction of wetlands for wastewater treatment. Wetlands are among the most biologically productive ecosystems, essential to the survival of more than one-third of the threatened and endangered species in the United States. ${ }^{239}$

Constructed wetlands recreate this biodiversity: Over six hundred species of plants and the full range of animal types are found in treatment wetlands in the United States. ${ }^{240}$ Constructed wetland systems also have the direct ancillary benefit of reducing carbon dioxide emissions by sequestering carbon through photosynthesis. ${ }^{241}$ Wetlands absorb carbon through vegetative growth and store it as preserved plant biomass. ${ }^{2+2}$ Furthermore, constructed wetlands absorb flood and surface water, reducing flooding and erosion damage to both natural and human environments. ${ }^{2 / 3}$

Finally, constructed wetlands provide public use benefits, supplying opportunities for hiking, biking, birdwatching, and scientific study. Building trails, boardwalks, and observation towers can open the wetland to the public and increase recreational and educational opportunities. $^{2+4}$ Each year, for example, ten thousand people visit the constructed wetlands at Orlando Easterly Wetlands Park, including area schools and community volunteers.

238 See Steven Piper and Jonathan Platt, Benefits from Including Wetland Component in Water Supply Projects, J Water Resources Planning and Mgmt 230 (July/Aug 1998). The magnitude of these ancillary benefits is difficult to quantify, and can be expected to vary as a function of species composition within the wetland and proximity to other wetlands. See J.H. Sather, Constructed Wetlands for Wastewater Treatment: Municipal, Industrial and Agricultural 353 (Lewis 1989). See also Portney and Stavins, $8 \mathrm{~J}$ Risk and Uncertainty at 117 (cited in note 186) (noting that regulations protecting forested wetlands "also protect wildlife habitat").

239 EPA, Office of Wetlands, Oceans, and Watersheds, Wetlands Fact Sheets (Mar 2002), available online at <http://www.epa.gov/owow/wetlands/facts/contents.html $>$ (visited Oct 3, 2002).

240 Knight, 35 Water Sci \& Tech at 36 (cited in note 236).

241 See M.H. Ogden, Atmospheric Carbon Reduction and Carbon Sequestration in Small Community Wastewater Treatment Systems Using Constructed Wetlands, available online at $<$ http://asae.frymulti.com> (visited Oct 3, 2002).

242 See EPA, Office of Wetlands, Oceans, and Watersheds, Functions and Values, available online at <http://www.epa.gov/owow/wetlands/vital/nature.html> (visited Sept 3, 2002).

243 See William S. Sipple, Wetland Function and Values, Module 6: Flood Protection (Mar 2002), available online at <http://www.epa.gov/watertrain/wetlands/index.htm $>$ (visited Sept 3 , 2002).

244 See Knight, 35 Water Sci \& Tech at 39 (cited in note 236).

245 David Sloan, et al, Reuse, Reclaim, and Recharge, 10 Water Envir \& Tech 56, 57 (1998). 
The availability of carbon sinks as a compliance mechanism under the Kyoto Protocol furnishes another example of a direct ancillary benefit in the context of environmental policy. ${ }^{2+5}$ In addition to effecting the primary goal of greenhouse gas reduction, the Protocol's reliance on carbon sinks will have the ancillary benefit of preserving forests in developing countries, thereby maintaining vital habitats and biodiversity, retarding erosion, and securing the welfare of local human populations. ${ }^{247}$

Article 12 of the Kyoto Protocol establishes the Clean Development Mechanism ("CDM"), which allows developed countries (Annex I) to earn emissions reductions through sustainable development projects in developing countries (non-Annex I). The emissions reductions for forest preservation are calculated against the baseline of expected emissions in the absence of the project, making projects most valuable in areas of impending destruction.

Article 12 recognizes the importance of terrestrial carbon sinks, including forests, to retard the processes that lead to global warming. Simply stated, as plants grow, carbon is absorbed from the atmosphere and stored in the biomass. ${ }^{249}$ When that biomass decays or is burned, carbon is released back in to the atmosphere. ${ }^{200}$ The Intergovernmental Panel on Climate Change estimates that deforestation is responsible for 10 to 30 percent of the anthropogenic carbon dioxide emitted over the past twenty years. About 20 percent of annual emissions come from the destruction of tropical forests. Deforestation of tropical forests continues at a rate of 40 million acres per year. ${ }^{2.1}$

246 See Kyoto Protocol to the United Nations Framework Commission on Climate Change (Dec 1997), available online at <http://unfccc.int/resource/docs/convkp/kpeng.html > (visited Sept 3,2002 ).

247 See generally Jocelyn Kaiser, Soaking Up Carbon in Forests and Fields, 290 Sci 922 (2000), available online at <http://www.sciencemag.org > (visited Sept 3, 2002); Ernst-Detlef Schulze, Christian Wirth, and Martin Heimann, Managing Forests After Kyoto, 289 Sci 2058 (2000), available online at <http://www.sciencemag.org > (visited Sept 3,2002).

248 See Donald M. Goldberg, Carbon Conservation: Climate Change, Forests, and the Clean Development Mechanism (1998), available online at <http://www.ciel.org/Publications/ CleanDevelopmentMechanismText.pdf $>$ (visited Sept 3,2002).

249 See, for example, Peter B. Reich, et al, Plant Diversity Enhances Ecosystem Responses to Elevated CO2 and Nitrogen Deposition, 410 Nature 810 (2001).

250 See World Resources Institute, Global Topics: Climate Change and Energy: The Global Carbon Cycle, available online at <http://www.wri.org/wri/climate/carboncy.html > (visited Sept 3, 2002). See also Robert A. Sedjo, Brent Sohngen, and Pamela Jagger, Carbon Sinks in the PostKyoto World, RFF Climate Issue Brief \#12, Resources for the Future (Oct 1998) (discussing the utility of forests as carbon sinks).

251 World Resources Institute News Release, WRI Study Reports Deforestation May Be Higher Than FAO Estimates (Mar 12, 2001), available online at <http://www.wri.org/press/ fao_fra5.html > (visited Sept 3,2002) (noting that its figure was higher than that of the UN FAO's 2001 assessment). 
The availability of carbon sinks as a compliance mechanism under the Kyoto Protocol creates incentives for forest preservation in countries where such action is currently economically impractical. ${ }^{22} \mathrm{At}$ the national level, the payoffs from selling a forest to an international logging concession usually outweigh the benefits of its being preserved. The rewards from logging accrue almost exclusively at the national level, while the damages are felt locally and globally. By allowing non-Annex I countries to sell carbon sinks to Annex I countries trying to meeting their emission reductions, the $\mathrm{CDM}$ provides a means for non-Annex I countries to earn income without externalizing costs at the local and global levels. ${ }^{23}$

It is appropriate, therefore, to think of the CDM as giving rise to a range of direct ancillary benefits: biodiversity preservation and watershed protection, fuel and timber conservation, and maintenance of nonwood forest products. ${ }^{24}$ Forests contain the greatest rates of biodiversity of any ecosystem type. Based on current deforestation rates, projections of extinction rates for forest species range from 2 to 5 percent per decade. ${ }^{2 s s}$ Particularly in tropical areas, where over half of the world's species are contained in only 7 percent of the land area, increasing forest conservation can slow extinction rates. ${ }^{26}$

Deforestation harms not only the species living within the forest, but also those in the surrounding watershed. Forests stabilize soils, maintain water quality and control water flows. Erosion rates in deforested areas can be up to one hundred times the natural rate, contributing to landslides, flooding, drinking water contamination and poor soil quality. ${ }^{27}$ Local people bear the impact of these harms, and also suffer the loss of the forest as a source of food, fuel, and livelihood. ${ }^{2 s}$

Direct ancillary benefits have also been observed in the context of health-and-safety regulation. According to a 1994 study, regulations implemented to limit the amount of carbon monoxide ("CO") in motor vehicle exhaust gas in order to reduce the long-term risks associated with air pollution had the ancillary benefit of reducing short-term

252 See C. Kremen, et al, Economic Incentives for Rain Forest Conservation Across Scales, 288 Sci $1828,1831(2000)$.

253 See Robert Bonnie, et al, Counting the Costs of Deforestation, 288 Sci 1763, 1763 (2000).

254 See Emily Matthews, et al, Pilot Analysis of Global Ecosystems: Forest Ecosystems 1

(World Resources Inst 2000).

255 Id at 51.

256 World Resources Institute, Global Issues: Tropical Forest Species Richness, available online at <http://www.wri.org/biodiv/b01-koa.html> (visited Sept 3,2002).

257 Matthews, et al, Pilot Analysis at 61-65 (cited in note 254).

258 See John L. Innes and Gary Bull, Forestry Management and Production, Encyclopedia of Life Sciences 1-5 (Nature Publishing Group 2001). 
carbon monoxide fatalities from accidents and suicides. ${ }^{209}$ The study found that because of regulatory initiatives and new technology, 1989 cars emitted less than one sixtieth the carbon monoxide when idling than 1967 cars. During roughly the same period, ${ }^{260}$ the number of accidental fatalities caused by $\mathrm{CO}$ was reduced by one half. ${ }^{261}$ At the same time, CO-induced suicides increased absolutely only trivially, well below the predictions of expected deaths in light of population growth and expansion in the absolute number of motor vehicles on the roads. The study shows that by 1987 , the CO regulations had the "unanticipated benefit" of saving an average of twenty-five thousand lives per year. By contrast, the regulations are only expected to save 212 to 551 lives annually from reduced air pollution. ${ }^{262}$ Thus, in this case, the ancillary benefit is considerably greater than the direct benefit.

\section{Ancillary benefits and substitution effects.}

The most compelling evidence of ancillary benefits rooted in substitution effects (or process changes) comes from recent studies of the ancillary benefits of greenhouse gas ("GHG") reductions for reductions in conventional pollutants. ${ }^{203}$ In order to reduce carbon dioxide $\left(\mathrm{CO}_{2}\right)$ emissions, electricity producers might burn less fuel or burn cleaner fuel. These transformations, designed to reduce $\mathrm{CO}_{2}$ emissions, would also reduce criteria air pollutants such as ozone, $\mathrm{NO}_{\mathrm{x}}$, and $\mathrm{SO}_{2}{ }^{264}$

Burtraw and Toman present and analyze eight different approaches to modeling these ancillary benefits. These models generate estimates for the average ancillary benefit per ton of carbon reduction

259 See Shelef, 146/147 Sci Total Envir at 93-94 (cited in note 18).

260 See id at 97 (referring to $1970-87$ as "the 18 years when large decreases in vehicle emissions were legislated in the USA").

261 Id at 97, table 4. Because of population growth during that period, and expansion in the number of motor vehicles, the number was expected to double. See id.

262 Id at 100.

263 See Dallas Burtraw, et al, Ancillary Benefits of Reduced Air Pollution in the United States from Moderate Greenhouse Gas Mitigation Policies in the Electricity Sector, Discussion Paper No 01-61 at 32-35 (Resources for the Future 2001), available online at <http://www.rff.org/ disc_papers/PDF_files/0161.pdf $>$ (visited Apr 20, 2002) (considering how moderate actions to slow atmospheric accumulation of greenhouse gases from fossil fuel use also could reduce conventional air pollutants in the United States); Burtraw and Toman, Discussion Paper No 98-01REV at *ii (cited in note 169) ("Policies that reduce emissions of greenhouse gases can simultaneously alter emissions of conventional pollutants that have deleterious effects on human health and the environment."). See also Luis Cifuentes, et al, Hidden Health Benefits of Greenhouse Gas Mitigation, 293 Sci 1257, 1259 (2001) (stating that, depending on how they are devised, "[p]olicies to mitigate GHG can yield substantive and immediate benefits to the 3 billion people currently residing in urban areas throughout the world").

264 Criteria pollutants are those regulated by Section 109 of the Clean Air Act. Reductions in criteria pollutants entail potentially significant health benefits. See Cifuentes, et al, $293 \mathrm{Sci}$ at 1259 (cited in note 263). 
ranging from $\$ 2.88$ to $\$ 78.85 .^{2.5}$ Burtraw and Toman note that the analysis of ancillary benefits gives rise to serious methodological difficulties. Nonetheless, they conclude by observing that "in assessing the cost of GHG control ... ancillary benefits clearly warrant attention.",260

In the more recent study, ${ }^{267}$ Burtraw and his coauthors model the effects on criteria air pollutant reductions of a moderate ( $\$ 25$ per metric ton) carbon tax. They find that such a tax would have ancillary benefits in criteria pollutant reductions worth about $\$ 13$ to $\$ 14$ per ton of carbon reduced. ${ }^{2 \alpha x}$ About $\$ 8$ of the ancillary benefits are attributable to nitrogen oxide $\left(\mathrm{NO}_{x}\right)$ reductions, ${ }^{269}$ while another $\$ 4$ to $\$ 7$ would come from avoided abatement costs for $\mathrm{NO}_{\mathrm{x}}$ and $\mathrm{SO}_{2}$ controls. ${ }^{270}$ They show that for a modest carbon tax, "ancillary benefits from reductions in $\mathrm{NO}_{\mathrm{x}}$ emissions contribute significantly to justifying the cost of carbon emission reductions."

\section{Health-health effects.}

It is in the nature of health-health tradeoffs that one cannot point to specific instances of negative side effects and attribute them to particular regulatory interventions. Rather, health-health tradeoffs are grounded in the general supposition that regulations, because they take an economic toll, take a toll on life as well. Not surprisingly, therefore, health-health ancillary benefits also cannot be specified with precision. But, as some commentators have perceptively noted, for health-health analysis to be true to its own assumptions, it has to be allowed that regulatory interventions that generate jobs or economic activity entail ancillary benefits. As Portney and Stavins have put it, "[I]f Superfund cleanups employ previously unemployed workers, or if air pollution regulations increase the incomes of those producing control equipment, their economic fortunes will improve andaccording to [health-health analysis] assumptions-so will their life expectancies." ${ }^{2 n}$

265 Burtraw and Toman, Discussion Paper No 98-01-REV at *18, table 5 (cited in note 169).

266 Id at $* 23$. This perspective is shared by the authors of the studies Burtraw and Toman review: "Studies ... indicate that significant reductions in $\mathrm{NO}_{\mathrm{x}}$ and $\mathrm{CO}$ are possible as a result of policies aimed primarily at reducing $\mathrm{CO}_{2}$ emissions." Id at $* 4$ (cited in note 169), citing Joel D. Scheraga and Susan S. Herrod, Assessment of the Reductions in Criteria Air Pollutant Emissions Associated with Potential CO2 Mitigation Strategies, Draft Report (EPA Office of Policy, Planning, and Evaluation, Climate Change Division 1993).

267 Burtraw, et al, Discussion Paper No 01-61 (cited in note 263).

268 Id at 33.

269 Id.

270 Id.

271 Id.

272 Portney and Stavins, $8 \mathrm{~J}$ Risk \& Uncertainty at 117 (cited in note 186). See also Lisa Heinzerling and Frank Ackerman, The Humbugs of the Anti-Regulatory Movement, 87 Cornell L Rev 648,669 (2002) (noting that "environmental protection is big business" and that people who 
A full analysis of the role, if any, that health-health analysis should play in regulatory policy is beyond the scope of this Article. It is important, though, to stress at least briefly that there are strong reasons to question the analytic soundness of the methodology and to suggest that health-and-safety and environmental regulations may have positive indirect ancillary effects.

First, while there is evidence of an association between wealth and health, the nature of the causal link is far from clear. Does less wealth produce worse health, possibly because of less access to quality medical care, as advocates of health-health tradeoffs maintain? Or does worse health produce less wealth because sick individuals are less likely to earn high incomes and more likely to have higher medical expenses? ${ }^{273}$ If the causal link were of the former type, then the use of health-health tradeoffs would arguably be appropriate. But if the link were of the latter kind, there would be absolutely no reason to assume that a regulation poses a countervailing risk simply because it costs money to meet its requirements. The direction of the causal link cannot be determined simply from the correlation between higher wealth and better health. A recent, sophisticated study attempted to determine this direction, but produced inconclusive results. ${ }^{274}$

Second, the ancillary effects of regulation are not necessarily limited to the health-health tradeoffs that arguably are produced by the regulation's compliance costs. The research and development efforts that lead to the production of pollution abatement technology may create ancillary benefits in the form of technological innovation. Strong proponents of this argument believe that these benefits can outweigh the costs of complying with the regulation, a proposition typically referred to as the "Porter hypothesis." controversial, ${ }^{276}$ but even if the ancillary benefits of the regulation do

work in all manner of jobs related to this business "are not poorer as a result of regulation," but richer). In the context of advancing a risk tradeoff argument, Viscusi has observed that "[r]egulatory requirements trigger a variety of economic activities, whether it be producing scrubbers for the reduction of air pollution, removing asbestos from schools, or driving a car back to the dealer after an automobile recall." 63 U Chi L Rev at 1451 (cited in note 9) (emphasis added). We see no reason why this observation should not support a claim for ancillary healthhealth benefits.

273 For a discussion of this dichotomy, see James P. Smith, Healthy Bodies and Thick Wallets: The Dual Relation between Health and Economic Status, 13 J Econ Persp 145, 147-48 (1999).

274 See id at 165.

275 See Michael Porter, The Competitive Advantage of Nations (Free Press 1990); Michael E. Porter and Claas van der Linde, Green and Competitive: Ending the Stalemate, 73 Harv Bus Rev 120 (Sept/Oct 1995); Daniel C. Esty and Michael E. Porter, Industrial Ecology and Competitiveness: Strategic Implications for the Firm, 2 J Indus Ecol 35 (1998); Anestasios Xepapadeas and Aart de Zeeuw, Environmental Policy and Competitiveness: The Porter Hypothesis and the Composition of Capital, 37 J Envir Econ \& Mgmt 165, 165 (1999).

276 See Adam B. Jaffe, et al, Environmental Regulation and the Competitiveness of U.S. Manufacturing: What Does the Evidence Tell Us?,33 J Econ Lit 132 (1995). 
not outweigh the cost of the regulation, these benefits are equally worthy of consideration as the risk tradeoffs.

Third, the argument in favor of the consideration of health-health tradeoffs is a second-best argument that is heavily dependent on maintaining the existing pattern of income distribution in our society. If Bill Gates has to pay $\$ 6$ million to save a statistical life, the expenditure is unlikely to have a negative effect on his health. ${ }^{2 m}$ On the other hand, if this cost is borne by the very poorest members of our society, a negative health consequence is far more likely. So, if the cost of meeting an environmental regulation has a negative health consequence, there are two obvious courses of action. The first, advocated by the proponents of health-health tradeoffs, is to make the regulation less stringent in light of this negative consequence. But there is a second alternative: affecting the incidence of the costs. There is no analytically compelling reason for unquestioningly preferring the former course of action over the latter.

\section{Lulling effects.}

Although we do not identify any specific examples, there is no reason to believe that there is not a category of ancillary benefits analogous to lulling effects. As a theoretical matter, we can imagine two different types of such ancillary benefits. First, we posit the existence of what might be called "attentiveness effects," whereby the promulgation of a health or safety regulation might, by reinforcing a norm, make people more sensitive to the need for safety beyond the circumstances expressly covered by the regulation. ${ }^{273}$ To take a stylized example, a regulation forbidding the use of handheld cell phones while driving might have the ancillary benefit of raising awareness about the need for road safety generally, and might therefore make people less likely to consume food and drink when driving.

Alternatively, these ancillary benefits might take the form of what might be called "relaxation effects," whereby individuals who are lulled into a state of reduced sensitivity to safety are paradoxically made safer. Thus, a regulation reducing the speed limit on a highway might have the ancillary benefit of even greater accident reduction than was targeted, because drivers who are made to feel calmer by the lower limits might (under certain circumstances) get into fewer accidents. ${ }^{2 i 9}$

277 See Heinzerling and Ackerman, 87 Cornell L Rev at 669 (cited in note 272).

278 For a general account of the expressive power of law in shaping norms, see Cass R. Sunstein, Symposium: Law, Economics, \& Norms: On the Expressive Function of Law, $144 \mathrm{U}$ Pa L Rev 2021 (1996).

279 See, for example, Sophie Fouvez, European Conference of Ministers of Transport Actions on Speed Moderation *5-6 (Apr 1998), available online at <http://www1.oecd.org/cem/ 
More generally, the literature on lulling effects does not convincingly establish the systematic presence of risk tradeoffs or absence of ancillary benefits. The best-developed account of lulling effects, presented by Viscusi, relies on three distinct phenomena. First, Viscusi notes that "regulations will lead to a reduction in safety-related efforts for the affected product." ${ }^{200}$ This effect, however, is not necessarily an instance of a welfare-reducing risk tradeoff. Assume, for example, that before seat belts are widely available individuals drive at 60 miles per hour (mph). After the use of seat belts is required, they begin driving at $65 \mathrm{mph}$ because they feel relatively safer. Compared to continuing to drive at $60 \mathrm{mph}$ with seat belts, is the higher speed socially undesirable? Presumably individuals derive net benefits from driving fasterfor example, in the form of reduced travel time-which outweigh the higher risks. Thus, absent negative externalities imposed on third parties (other drivers or bystanders), the increased speed is socially desirable. With negative externalities, of course, the result is ambiguous because the driver's increased welfare may or may not outweigh the reduced welfare of the third parties.

Second, Viscusi refers to the "indivisibility of individuals' safetyrelated actions." ${ }^{251} \mathrm{He}$ observes that to the extent parents are less careful with prescription drugs that have safety caps, their diminished responsibility may extend to harmful substances without safety caps. For example, instead of placing all their medicines in a safety-latched drawer, they may begin leaving all of them-both the protected and unprotected ones-on the kitchen counter. In this manner, "safety caps will increase poisoning rates for [ ] unprotected products. ${ }^{, 223}$ But the indivisibilities to which Viscusi refers may also have the opposite effect. They could raise the awareness of consumers to the poisoning risks posed by medicines, leading them to exhibit more care with respect to the unprotected products. There are no analytically compelling reasons for believing that such indivisibilities will produce risk tradeoffs rather than ancillary benefits, or that the former would be greater than the latter.

The third, and perhaps central, claim is that "regulation may induce consumer misperceptions regarding the importance of precau-

online/speeches/sfserock98.pdf $>$ (visited Oct 2, 2002) (noting that accident reduction "is no longer solely a question of imposing a speed limit" but of "combining speed limits with measures relating to the vehicle, its environment, and driver, with a view to attaining ... calmer driving").

280 W. Kip Viscusi, The Lulling Effect: The Impact of Child-Resistant Packaging on Aspirin and Analgesic Ingestions, 74 Am Econ Rev Papers \& Proceedings 324 (1984).

281 See W. Kip Viscusi, Consumer Behavior and the Safety Effects of Product Safety Regulation, 28 J L \& Econ 527, 539 (1985). See also Viscusi, 74 Am Econ Rev Papers \& Proceedings at 324 (cited in note 280 ).

282 Viscusi, $28 \mathrm{~J} \mathrm{~L} \&$ Econ at 539 (cited in note 281). See also Viscusi, 74 Am Econ Rev Papers \& Proceedings at 324 (cited in note 280 ). 
tions." ${ }^{2 \times 3}$ This effect arises "[t]o the extent that consumers tend to ignore very-low-probability events." ${ }^{234}$ It is possible, of course, that in some cases consumers behave in this manner. But the literature on risk regulation also features prominently the opposite phenomenon: the overestimation of small risks. In fact, the prevalent complaint by advocates of regulatory reform is that regulatory policy pays excessive attention to small risks relative to more serious ones. ${ }^{225}$ More generally, a socially undesirable lulling effect is present only if consumers accurately assessed the preregulation risk but underestimated the residual risk that remains with regulation, or if they underestimated the residual risk more than the preregulation risk.

Viscusi's empirical study found that child resistant caps did not reduce risk, apparently as a result of "increased parent responsibility, such as leaving off the caps of bottles." ${ }^{256}$ But the fact that the net ancillary effects were negative in that instance does not imply that they would also be negative across different types of risks.

\section{RISK TRADEOFFS IN THE REGULATORY PROCESS: INSTITUTIONAL BIAS}

We have seen how risk tradeoff analysis invites legislators, regulators, judges, and academics to consider only the ancillary harms of regulatory interventions and not their ancillary benefits. The methodology thus provides a biased metric for the assessment of regulatory impacts. This problem could be rectified by coupling risk tradeoff analysis with ancillary benefit analysis, as we advocate in this Article. ${ }^{28}$

But there is also a different, though related, problem that stems not from the methodology itself but from the manner in which the processes of executive and judicial review of regulation privilege antiregulatory forces invoking the ancillary harms of regulation over proregulation forces invoking its ancillary benefits. The precursor to both institutional biases is the agencies' failure to consider ancillary effects of its regulation, whether positive or negative. In Part IV.A, we discuss this phenomenon, which, we argue, results from tunnel vision. ${ }^{2 \Omega}$ Agency decisionmakers focus exclusively on one or some aspects of a complex problem, as members of a highly balkanized bureaucratic

283 See Viscusi, $28 \mathrm{~J} \mathrm{~L} \&$ Econ at 539 (cited in note 281).

284 Id.

285 See Cass R. Sunstein, The Laws of Fear, 115 Harv L Rev 1119, 1119-20 (2002); Breyer, Breaking the Vicious Circle at 11-19 (cited in note 5).

286 Viscusi, $28 \mathrm{~J} \mathrm{~L} \&$ Econ at 553 (cited in note 281).

287 See text accompanying notes $339-46$.

288 See Breyer, Breaking the Vicious Circle at 11 (cited in note 5) (showing how this narrow focus can ultimately bring about more harm than good). 
structure. ${ }^{289}$ As a result, they do not consider the full implications of their decisions.

In Part IV.B, we turn to the systemic imbalance in OMB's review of regulation. This bias arises because OMB primarily sees its mandate as reining in the regulatory impulses of administrative agencies. Thus, when OMB examines the costs and benefits of regulation, it focuses on risk tradeoffs and not on ancillary benefits.

In Part IV.C, we show how the doctrines of judicial review privilege the interests of challengers seeking less stringent regulation over those of challengers with the opposite interests. Because the former benefit from delaying regulations whereas the latter do not, risk tradeoff arguments are more likely to be raised in the courts than ancillary benefit arguments.

\section{A. Administrative Agencies}

Ideally, an omniscient regulator working at an administrative agency with limitless resources would carefully consider and weigh all ramifications of a potential rule and decide accordingly whether and how to regulate. In practice, agencies either ignore altogether, or fail to consider adequately, the ancillary positive and negative effects of regulation. There are three closely related explanations for the disjunction between the ideal and the actual scenarios. First, there is an ontological claim about the nature of the problems being addressed. Health-and-safety risks of the kind targeted by regulatory intervention are parts of complex wholes. Aspects of a problem might fall under the legal or technical competence of a particular agency or subagency division, but the problem as a whole is likely to cut across bureaucratic boundaries.

Second, there is a cognitive psychological argument about the agency decisionmakers. "[L]ike individual citizens and the public as a whole," as Sunstein has put it, they "suffer from both limited information and (even more importantly) selective attention.".20 Graham and Wiener similarly portray the "fixation on a specific symptom" as a feature of the decisionmaking process. ${ }^{291}$

A third line of analysis, informed by neoinstitutionalist political science, concentrates on the manner in which the bureaucratic structures in place both across and within agencies influence regulatory decisions. $^{222}$ Agencies or branches of agencies given jurisdiction over one

289 See Wiener and Graham, Resolving Risk Tradeoffs at 235 (cited in note 34) (discussing the phenomenon of "bounded oversight roles in the administrative state").

290 Sunstein, 63 U Chi L Rev at 1536 (cited in note 3).

291 Wiener and Graham, Resolving Risk Tradeoffs at 235 (cited in note 34).

292 See, for example, J. Clarence Davies and Jan Mazurek, Pollution Control in the United States: Evaluating the System 16-22 (Resources for the Future 1998) (discussing the influence of 
particular issue or set of issues are likely to ignore - or at least downplay $^{233}$-the effect of their own regulations on matters beyond their technical and legal competence. ${ }^{2 \times}$

The problems of fragmentation are particularly acute in the context of environmental regulation. Professor Richard Stewart has recently written: "For all its past successes, the U.S. environmental regulatory system has a fundamental flaw. It consists of a patchwork of detailed and rigid laws that are largely unrelated to each other and are lacking in any unified vision of environmental problems or EPA's mission." Two other scholars have dubbed fragmentation "[t]he most obvious and important characteristic of pollution control."206 Of the nine major environmental statutes, ${ }^{297}$ three are organized by medium (air, ${ }^{2 / 3}$ water, ${ }^{259}$ drinking water ${ }^{300}$ ), another is organized by type of product (pesticides), ${ }^{301}$ one targets toxic substances in general, another, cleanups of hazardous substances, ${ }^{303}$ and two deal with the provision of information. ${ }^{3.4}$ The EPA, in turn, replicates in its bureaucratic organization the complexity characterizing the statutes it administers.

the EPA's fragmented bureaucratic structure on pollution legislation). For a general discussion of integrating the EPA to combat pollution, see Symposium: Integrated Pollution Control, 22 Envir L 1 (1992).

293 For our purposes, it does not matter whether the agencies are self-conscious in their inability to tackle certain complex problems, or are unaware of the implications their administrative decisions have for decisionmakers working in different offices or different agencies altogether. Our point about the fragmentation of the decisionmaking process applies either way. Some commentators have focused on fragmentation as the source of an adversarial relationship between offices within an agency. See Marc K. Landy, Marc J. Roberts, and Stephen R. Thomas, The Environmental Protection Agency: Asking the Wrong Questions from Nixon to Clinton 31617 (Oxford 1994).

294 See Whipple, $9 \mathrm{Reg}$ at 37 (cited in note 44) (describing various ways regulation may merely transfer risk instead of reducing it).

295 Stewart, 29 Cap U L Rev at 153 (cited in note 25).

296 Davies and Mazurek, Pollution Control at 16 (cited in note 292).

297 Id at 11. For an example of a call for greater statutory coherence at EPA, see Robert M. Sussman, Should Environmental Laws Be Integrated?, 15 Pace Envir L Rev 57, 62-66 (1997) (calling for an "integrating statute" to serve as an overlay on the existing environmental statutes).

298 Clean Air Act, 42 USC $\$ 7401$ et seq (2000).

299 Federal Water Pollution Control Act, 33 USC $\$ 1251$ et seq (2000).

300 Public Health Service Act, 42 USC $\$ 201$ et seq (2000).

301 Federal Insecticide, Fungicide, and Rodenticide Act, 7 USC $\$ 136$ et seq (2000).

302 Toxic Substances Control Act, 15 USC $\$ 2601$ et seq (2000).

303 Comprehensive Environmental Response, Compensation, and Liability Act of 1980 (CERCLA), 42 USC $\$ 9601$ et seq (2000).

304 National Environmental Policy Act of 1969, 42 USC \& 4321 et seq (2000); Emergency Planning and Community Right-to-Know Act of 1986, 42 USC $\$ 11001$ et seq (2000). See Davies and Mazurek, Pollution Control at 11-12 (cited in note 292). See also Walker and Wiener, Recycling Lead at 150 (cited in note 198) ("The fragmentation in EPA programs and regulations largely reflects the narrow focus of the original statutes passed by Congress to protect the air, surface waters, drinking water, and food supply, and to manage hazardous and solid wastes.").

305 For a general discussion, see Thomas O. McGarity, The Internal Structure of EPA Rule- 
In addition, its various policymaking, economically-oriented, and legal staffs bring to the organization different professional and ideological commitments that themselves stand in the way of internal coherence. ${ }^{306}$ As a practical matter, the statutory background of environmental law and the bureaucratic layout of the EPA stand in the way of an integrated approach to risk regulation. ${ }^{307}$

Graham and Wiener argue persuasively that the "fragmentation of decisionmaking into specialized roles with bounded oversight responsibilities" ${ }^{309}$ is an important source of risk tradeoffs. Regulatory decisionmakers fail to consider risk tradeoffs precisely because those harms often fall under a bureaucratic responsibility different from their own. ${ }^{309}$ Their argument, however, applies with equal force to the consideration of ancillary benefits. Agency decisionmakers fail to consider the ancillary effects of proposed regulation precisely because those effects fall outside the ambit of their specific legal authority or technical competence. ${ }^{310}$

The EPA's approach to the risk tradeoffs of the new ozone NAAQS provides a useful example of how fragmentation promotes inattention to ancillary effects in risk regulation. ${ }^{311}$ During notice and comment rulemaking, the EPA was presented with-and ultimately rejected-numerous arguments about how tropospheric ozone might have beneficial effects in protecting against ultraviolet radiation. ${ }^{3 / 2}$

making, 54 L \& Contemp Probs 57 (Autumn 1991) (describing EPA's decisionmaking processes and bureaucratic structures).

306 See Landy, Roberts, and Thomas, Environmental Protection Agency at 11 (cited in note 293) ("Because the [EPA] is responsible for many different aspects of policymaking ... it employs a wide rage of professionals including lawyers, economists, and engineers .... [Their] differences often breed misunderstanding and conflict."). See also Davies and Mazurek, Pollution Control at 17 (cited in note 292) ("Many of the pollution control technologies now used to meet regulatory requirements do not really control the pollution - they simply shift it around, change its form, or delay its release into the environment.").

307 Thus, for instance, regulators who care about clean air might be less concerned with sludge produced by coal scrubbers. See Bruce A. Ackerman and William T. Hassler, Clean Coal Dirty Air: Or How the Clean Air Act Became a Multibillion-Dollar Bail-Out for High-Sulfur Coal Producers and What Should Be Done about It 31-54 (Yale 1981).

308 Wiener and Graham, Resolving Risk Tradeoffs at 235 (cited in note 34). As they put it: "The jurisdictions of administrative agencies tend to be defined by categorical boundaries that countervailing risks do not respect." Id at 237.

309 "The mission orientation of such agencies ... leads to a form of "bureaucratic externality' in which the agency tends to ignore or discount the adverse effects of its choices on values or goals that are not central to its mission." Stephen G. Breyer, et al, Administrative Law and Regulatory Policy: Problems, Text, and Cases 352 (Aspen 4th ed 1998).

310 See Davies and Mazurek, Pollution Control at 18 (cited in note 292) ("Major problems in the future are likely to be cross-media problems, and they will go unrecognized for a long time if we try to detect them through programs that focus on only one medium of the environment.").

311 See text accompanying notes $50-66$.

312 See Marchant, 11 Tulane Envir L J at 274-75 (cited in note 54) (explaining how the EPA refused to consider the health benefits of ground-level ozone in its decision to revise the ozone standard). 
Later, when industry groups challenged the regulation in court on the grounds that the EPA had failed to consider the risk tradeoff of tighter ozone standards, the EPA took the position that it was legally barred from considering ancillary effects and that those effects were properly considered under a different part of the Clean Air Act. ${ }^{313}$ As discussed above, the D.C. Circuit rejected this argument. ${ }^{314}$

To some extent, the EPA has attempted to address the problems of fragmentation. In particular, the emergence of "clusters," policymaking teams that bring together members of various programs, is an important step toward a more integrated approach to regulation. ${ }^{315}$ But the efforts have been limited. In summary, fragmentation, coupled with selective attention, limited time, and finite resources, creates strong incentives for agency decisionmakers to focus almost exclusively on the primary effects of regulation and largely overlook the ancillary effects.

This inattention to ancillary effects is not, on its face, biased; agency officials tend to ignore all ancillary effects, not only ancillary benefits. But, as we show in Parts V.B and V.C, it is the root cause of biases that emerge as a result of the executive and judicial review of administrative actions. ${ }^{316}$

\section{B. $\mathrm{OMB}$}

With the issuance of Executive Order 12291 in the first month of the Reagan Administration, the White House, acting through OIRA, asserted unprecedented oversight authority over the regulatory state. ${ }^{3.17}$ There is broad consensus that $\mathrm{OMB}$ has consistently viewed its

313 "EPA interprets the NAAQS-setting provisions to focus only on the characteristics of ground-level ozone that made it a 'pollutant'-i.e. its adverse health effects-and not its potential use as an ameliorating agent to reduce different health risks caused by a different problem." EPA Brief on Ozone NAAQS, American Trucking Assoc v EPA, 97-1440, *58 (DC Cir 1999) . The EPA also argued that the purported health benefits of tropospheric ozone could not be adequately quantified. See id at 64.

314 See American Trucking, 175 F3d at 1051-53 (rejecting the idea that the EPA is barred from considering the ancillary effects of a pollutant). See also text accompanying notes 50-63. Although neither party petitioned for certiorari on this matter, Justice Breyer did cite approvingly to Judge Williams's risk tradeoff analysis in his concurring opinion. See 531 US at 457 (Breyer concurring in part and concurring in the judgment). See also text accompanying notes 157-59.

315 See Wiener and Graham, Resolving Risk Tradeoffs at 253 (cited in note 34).

316 In addition, in the wake of new case law like the D.C. Circuit's opinion in American Trucking, it may now be the case that agencies are attentive to risk tradeoffs but not ancillary benefits.

317 See Elliott, 57 L \& Contemp Probs at 167-68 (cited in note 27) (describing the OMB's broad powers); Olson, 4 Va J Natural Resources L at 10-12, 40 (cited in note 26) (explaining the significance of Executive Order 12291, which gave OMB the authority to ensure that all informal executive agency rules conform to certain broad-based economic rules). Executive Order 12291 has been the subject of extensive academic and policy debate. See, for example, Christopher C. 
task under the Executive Order as being "to drive regulation in a direction (towards deregulation) different from that which the delegees [that is, the agencies themselves] would have chosen." "318 If OMB were truly interested in promoting rationality in the regulatory process, it would be as concerned with regulations that undervalue benefits or overvalue costs as with regulations that overvalue benefits or undervalue costs. But throughout its history, OMB has concerned itself with the latter and not the former. ${ }^{319}$ Not until very recently has OMB ever used its oversight authority to call attention to the possible unexplored benefits of regulation." "OIRA's basic mission has been to stop unjustified rules, mainly through the use of 'return letters,' requiring agencies to reconsider their proposals."

Given OMB's outlook, it is not surprising that it would concern itself with risk tradeoffs that the agency might have overlooked, and not with ancillary benefits. ${ }^{322}$ Drawing attention to risk tradeoffs might delay the implementation of a regulation while the agency considers the matter, ${ }^{323}$ or it might prevent the regulation from ever being prom-

DeMuth and Douglas H. Ginsburg, White House Review of Agency Rulemaking, 99 Harv L Rev 1075, 1076 (1986) (noting that President Reagan's initiatives provoked intense controversy).

318 Elena Kagan, Presidential Administration, 114 Harv L Rev 2245, 2280 (2001). See also Mark Seidenfeld, The Psychology of Accountability and Political Review of Agency Rules, 51 Duke L J 1059, 1069 (2001) (noting that OIRA personnel focus on the costs of regulation, "which makes it likely that they will object to a rule if there is uncertainty" whether benefits outweigh costs); Alan B. Morrison, OMB Interference with Agency Rulemaking: The Wrong Way to Write a Regulation, 99 Harv L Rev 1059, 1065 (1986) ("The Administration has principally used the system of OMB review created by the Executive Orders to implement a myopic vision of the regulatory process which places the elimination of cost to industry above all other considerations.").

319 See Olson, 4 Va J Natural Resources $\mathrm{L}$ at 54-55 (cited in note 26) (observing that OMB does not undertake cost-benefit analyses of proposed rules that would relax standards).

320 In September 2001, John Graham, the new OIRA Administrator, sent two "prompt letters" to agencies suggesting potentially beneficial regulation. Two features of these letters are unique in the practice of regulatory oversight. First, the letters are prospective: They propose new regulation, rather than reviewing regulation that has already been proposed. Second, the letters show a recognition on the part of OMB that additional regulation can be beneficial. See Office of Management and Budget, Press Release, OMB Encourages Lifesaving Actions by Regulators (Sept 18, 2001), available online at $<\mathrm{http} / / \mathrm{www}$. whitehouse.gov/omb/pubpress/200135.html> (visited Apr 20, 2002); Robert W. Hahn and Cass R. Sunstein, Regulatory Oversight Takes Exciting New Tack*1, Policy Matters No 01-25 (AEI-Brookings Joint Center for Regulatory Affairs 2001), available online at <www.aei.brookings.org > (visited Sept 3,2002).

321 Hahn and Sunstein, Policy Matters No 01-25 at:1 (cited in note 320). Professor Kagan has suggested that the role of presidential oversight during the Clinton administration "disprove[ed] the assumption some scholars have made ... that presidential supervision of administration inherently cuts in a deregulatory fashion." Kagan, 114 Harv L Rev at 2248-49 (cited in note 318 ). But by "presidential oversight," Kagan means something much broader than OMB review.

322 See text accompanying notes $137-49$.

323 See Olson, 4 Va J Natural Resources $L$ at $48-49$ (cited in note 26) (noting that for the proposed EPA rules with which OMB disagrees, delay in regulatory action is the norm). 
ulgated, by showing that it was excessively costly. ${ }^{34}$ Either way, when an agency, because of tunnel vision, does not concern itself with either risk tradeoffs or ancillary benefits, $\mathrm{OMB}$, because of its institutional bias against regulation, is more likely to require the agency to relax its regulation because of risk tradeoffs than to require the agency to tighten the regulation because of ancillary benefits.

\section{The Courts}

The antiregulatory bias produced by judicial review of administrative action is conceptually quite different than that resulting from OMB's oversight. The courts, unlike OIRA, do not have a structural aversion to regulation..$^{325}$ Rather, the antiregulatory bias in the courts potentially emerges as the result of doctrines governing the judicial review of administrative action and the incentives to bring litigation, which combine to privilege risk tradeoffs over ancillary benefits.

As we explained above, because of fragmentation, agencies can be expected to fail to consider the ancillary effects of new regulations. $^{326}$ If those regulations are then challenged in court on the grounds that risk tradeoffs were not considered, the agency may not respond, as a matter of black-letter administrative law, by pointing to potentially offsetting ancillary benefits. Thus, legal doctrine provides an advantage to the would-be challenger of regulation over the agency that must defend the regulation in court.

In addition, organizations that challenge regulations as excessively stringent (paradigmatically, industry groups) have well-aligned incentives to bring such litigation, while organizations that challenge regulations as insufficiently stringent (typically advocacy groups) have conflicting incentives to do so. This disparity in incentives to bring suit also contributes to an insidious antiregulatory bias in the courts.

1. Bias by waiver: Chenery and related doctrines.

The rule announced in $S E C v$ Chenery $\operatorname{Corp}^{327}$ requires that a court reviewing administrative action confine its review "to a judgment upon the validity of the grounds upon which the [agency] itself

324 See id at 43 ("In practice ... OMB has acquired a de facto veto power over certain [EPA] regulations.").

325 Individual judges might harbor such sentiments. See Richard L. Revesz, Environmental Regulation, Ideology, and the D.C. Circuit, 83 Va L Rev 1717, 1743-46, 1760-64 (1997) (testing the significance of intraparty and interparty differences in the voting records of individual judges); Richard L. Revesz, Ideology, Collegiality, and the D.C. Circuit: A Reply to Chief Judge Harry T. Edwards, 85 Va L Rev 805, 840-43 (1999) (explaining ideological differences over procedural challenges).

326 See Part IV.A.

327318 US 80 (1943). 
based its action.", The Chenery Court stated: "If an order is valid only as a determination of policy or judgment which the agency alone is authorized to make and which it has not made, a judicial judgment cannot be made to do service for an administrative judgment., ${ }^{329}$ Thus, the reviewing court is not free to find new grounds on which to justify an agency's decision. This doctrine implies that when a challenger complains that the agency failed to consider risk tradeoffs, the reviewing court will not be able to substitute its view that a regulation ought to be found legal because the ancillary benefits that the agency overlooked are at least as large as the ancillary harms.

Moreover, the agency would probably not even be able to bring to the court's attention any ancillary benefits not considered in the administrative process. Conceptually related to the Chenery doctrine is the rule that when a regulation is being challenged, "the courts may not accept appellate counsel's post hoc rationalizations for agency action. ${ }^{, 30}$ Whereas groups challenging regulation are free to introduce evidence of risk tradeoffs not considered by the agency, the agency lawyers may not counteract the argument by pointing to evidence of ancillary benefits for the first time during the course of litigation. By ignoring ancillary effects during rulemaking, the agency effectively waives its right to invoke them in litigation. The result is an antiregulatory bias that draws more judicial attention to tradeoffs than ancillary benefits.

The effect of this rule in creating a bias favoring risk tradeoffs over ancillary benefits is reinforced by another doctrinal strut of judicial review. A central task of the reviewing court is to determine whether the agency adequately considered all the relevant factors during the course of the administrative proceeding. ${ }^{331}$ As a result, if an agency's counsel or a challenger seeking more stringent regulation points to the existence of ancillary benefits as a means of counteracting risk tradeoffs, the outcome might be perverse. Instead of making the regulation appear more desirable, such a strategy would provide

328 Id at 88. See also Bell Atlantic Telephone Co v FCC,206 F3d 1,9 (DC Cir 2000) (remanding case under Chenery for lack of an adequate explanation of the challenged FCC rulings).

329 Chenery, 318 US at 88.

330 Motor Vehicle Manufacturers Assoc of the U.S., Inc v State Farm Mutual Auto Ins Co, 463 US 29, 51 (1983). See also Citizens to Preserve Overton Park, Inc v Volpe, 401 US 402,419 (1971) (declining to consider as part of the record on appeal materials deemed post hoc rationalizations).

331 See, for example, Corrosion Proof Fittings $v$ EPA, 947 F2d 1201, 1215 (5th Cir 1991) (holding that the EPA failed, under the TSCA, to supply sufficient evidence to justify its proposed ban on asbestos); Ethyl Corp v EPA, 541 F2d 1, 66-67 (DC Cir 1976) (en banc) (Bazelon concurring) (expressing the preference that administrative decisionmakers present information to reviewing courts in clear and nontechnical fashion). 
an independent reason for a remand: that the agency did not take ancillary benefits into account.

2. The incentives to challenge regulation.

Challenges to the legality of regulation are a perennial feature of the administrative state, and tend to come from all sides. Industry groups argue against the restrictiveness of regulation, while advocacy groups of different kinds argue that such regulations are not expansive enough. But even though in one sense the industry and advocacy groups are the mirror images of one another, their incentives to bring litigation challenging a regulation are importantly different.

The incentives of antiregulatory challengers to invoke risk tradeoffs are well aligned. Such challengers aim to bring about less stringent regulation. Where a court agrees that an agency has failed to justify the stringency of its new rule, the court is likely to vacate the regulation pending a remand to the agency to reconsider the matter more exhaustively. While the regulation is being reconsidered by the agency on remand, the preexisting (and, by hypothesis, less stringent) ${ }^{332}$ regulatory scheme remains in effect. Under those circumstances, the challenger stands to win not only in the long run, insofar as the agency ultimately might not be able to defend the new regulation, but also in the short run, because the less stringent old rule will typically remain in effect while the new rule is being reconsidered.

In contrast, challengers seeking more stringent regulation face conflicting incentives. The prospect of more stringent regulation is, of course, desirable to such challengers - that is the reason they bring suit in the first place. However, the possibility that the regulations might be vacated during a remand-a likely result if the challenger prevails in court-is unattractive. This is because vacatur means that the pre-existing, less stringent rule will remain in effect while the agency reconsiders the present rule. ${ }^{333}$ Thus, the proregulation challenger's incentive to bring suit to effect a long-term increase in the new regulation's stringency is undercut by the worry that a legal "vic-

332 We acknowledge that the force of this argument depends upon the assumption that the new regulation imposes more, not less, stringent requirements.

333 As we discuss below, in the 1990s, the D.C. Circuit began to remand cases to administrative agencies without vacating. See, for example, Allied-Signal, Inc v U.S. Nuclear Regulatory Commission, 988 F2d 146, 154 (DC Cir 1993) (remanding without vacating). See also Cass R. Sunstein, Is the Clean Air Act Unconstitutional?, 98 Mich L Rev 303,372-73 \& n 299 (1999):

The rules should be held unlawful, and remanded to the agency; but they should not be vacated, at least when the agency can show (a) that it might be able to generate a justification that will satisfy judicial review, and (b) that invalidation of the rule may generate significant risks.

Nevertheless, the ordinary practice of that court is to vacate a rule upon remand. See, for example, Illinois Public Telecommunications Association v FCC, 123 F3d 693, 693 (DC Cir 1997). 
tory" might create an even less stringent standard than the one embodied by the new (disputed) regulation. Nor should the fact that a remand is (nominally) only a temporary source of comfort to proregulation challengers. As the leading empirical study in this area has shown, in only about 20 to 25 percent of remands does the agency end up reaffirming its original decision. ${ }^{334}$

As a result of this asymmetry in the respective payoffs of bringing suit, other things being equal, a reviewing court is more likely to be presented with antiregulatory challenges to regulation than proregulatory challenges, and that it is therefore more likely to be presented with arguments grounded in risk tradeoffs than ancillary benefits.

The force of this argument is potentially weakened by the emerging trend on the D.C. Circuit to remand regulations to agencies without vacating them. ${ }^{335}$ Were remand without vacatur to become the general rule rather than the exception (albeit an increasingly robust one), or were the D.C. Circuit deliberately to apply this remedy only (or chiefly) when suit is brought challenging an agency action as insufficiently stringent, our incentive-based claim might be significantly undermined. Neither appears to be the case.

First, although some commentators have referred to this remedy as "standard operating procedure" on the D.C. Circuit, the court has itself maintained that the general rule remains to vacate administrative actions upon remand. ${ }^{37}$ Second, the D.C. Circuit has never indicated a preference for remanding without vacating where suit is brought challenging a new rule as insufficiently stringent. Instead, it has repeatedly relied on the two-factor test set out in Allied-Signal, Inc $v$ U.S. Nuclear Regulatory Commission ${ }^{335}$ to determine when remand without vacatur is appropriate. Thus, there is no reason to believe that the trend toward increasing reliance on remand without vacatur will mitigate the institutional bias in the courts in favor of risk tradeoffs (and against ancillary benefits) generated by significant differences in the incentives to bring suit challenging regulations.

334 Peter H. Schuck and E. Donald Elliott, To the Chevron Station: An Empirical Study of Federal Administrative Law, 1990 Duke L J 984, 1047 ("[Our findings show that] agencies reaffirmed their original decisions in only 20-25 percent of the remanded cases.").

335 See Brian S. Prestes, Remanding without Vacating Agency Action, 32 Seton Hall L Rev 108,109 (2001) ("[C]ourts have increasingly . . . remand[ed] . . . without vacating the regulation.").

336 See Frank H. Wu and Denisha S. Williams, Remand without Reversal: An Unfortunate Habit, 30 Envir L Rep 10193, 10194 (Mar 2000).

337 See, for example, Illinois Public Telecommunications Association, 123 F3d at 693.

$338988 \mathrm{~F} 2 \mathrm{~d} \mathrm{146,150-51}$ (DC Cir 1993) (stating that the decision to vacate depends on the seriousness of the deficiencies and the disruptive consequences of an interim change). 


\section{ANCILLARY BENEFITS ANALYSIS IN THE AgENCIES: A CASE STUDY AND ITS LESSONS}

In this Part, we offer a solution to counteract the methodological and institutional biases of risk tradeoff analysis. Our core proposal is simple: Decisionmakers in administrative agencies should consider the positive side effects brought about by regulatory interventions, and not merely the negative side effects. In so doing, they will be able to assess thoroughly and accurately the risk portfolio of a regulatory intervention.

Ideally, other decisionmakers throughout the administrative state-particularly judges, OMB officials, and legislators-would take responsibility for implementing ancillary benefit analysis. We are skeptical, however, for reasons discussed in Part IV, that there is any effective substitute for attention to ancillary benefit analysis on the part of regulatory agencies. First, the doctrines of judicial review that privilege risk tradeoffs over ancillary benefits are unlikely to be overturned. Second, for the foreseeable future, OMB's principal institutional commitment will probably continue to focus on reducing the burden of regulation. ${ }^{338}$ This antiregulatory perspective, which fits comfortably with risk tradeoff analysis, is not conducive to the consideration of ancillary benefit analysis.

Third, it is unlikely that in the near future Congress will address the biases raised by risk tradeoff analysis. Comprehensive regulatory reform legislation has been stalled in Congress for a long time in part as a result of the phenomenon of divided government. Were Congress to enact such legislation in the future, however, it is important that, unlike the situation in prior bills, ${ }^{3 / 3}$ any requirement for risk tradeoff analysis be coupled with a requirement for ancillary benefit analysis. Parity in this context is important. There is no justifiable reason for requiring the former and remaining silent on the latter.

For these reasons, the primary burden for implementing ancillary benefit analysis must fall squarely on the agencies themselves. We see three reasons to be cautiously optimistic about the agencies' ability and willingness to investigate ancillary benefits, despite the problem of tunnel vision discussed above. ${ }^{311}$ First, our Article shows more clearly than ever before the disadvantages of not considering ancillary benefits. ${ }^{322}$ Second, agencies have been compelled by reviewing courts

339 See, for example, Michael Grunwald, Business Lobbyists Asked to Discuss Onerous Rules: GOP Aide Identifies 57 Regulations to Target, Wash Post A3 (Dec 4, 2001) (relating that Graham, the administrator of OIRA, asked a senior Republican congressional aide to convene lobbyists and identify and rank onerous regulations).

340 See text accompanying notes $125-36$.

341 See text accompanying notes $290-310$.

342 See text accompanying notes $287-89$. 
to undertake risk tradeoff analysis. ${ }^{3 / 3}$ Once they have been forced to overcome the limitations of tunnel vision to consider risk tradeoffs, agencies will find it relatively easier to consider ancillary benefits. Finally, as we have shown, agencies have independently begun to undertake measures to remedy fragmentation. ${ }^{3+4}$ These measures will prove useful in helping agencies to consider ancillary benefits in the rulemaking process.

In Part V.A, we present a case study to illustrate how an agency might carry out this task. Part V.B shows that the federal environmental statutes permit-perhaps should even be interpreted to require-ancillary benefit analysis. Part V.C advances a "mirror image" principle: There should be parity in the treatment of risk tradeoffs and ancillary benefits.

\section{A. A Case Study of Ancillary Climate Change Benefits}

Our case study shows how policies targeting conventional pollutants can be expected to lead to meaningful reductions in GHG emissions. ${ }^{3.5}$ These reductions in criteria pollutants have beneficial health and environmental consequences in the United States. We focus on the regulatory regimes targeting two criteria pollutants: sulfur dioxide and ozone, which are regulated under Section 109 of the Clean Air Act. But our method might also be useful for the evaluation of the GHG-related ancillary benefits of regulatory regimes directed at other criteria air pollutants. Indeed, we hope that our case study will prompt the EPA to adopt an off-the-rack model that would permit it systematically to study beneficial climate change consequences of regulations directed at reductions in criteria air pollutants.

1. Clean fuels and energy conservation.

Global warming is the process by which the presence in the atmosphere of GHGs - mainly carbon dioxide, methane, and nitrous oxide-trap energy given off by the earth, thereby leading to increases in temperature. ${ }^{347}$ The negative consequences include sea level rises and

343 See text accompanying notes $62-63$.

344 See text accompanying note 315 .

345 Our case study presents the mirror image of the one described by Burtraw and Toman, which investigated the ancillary benefits of $\mathrm{CO}_{2}$ reductions for criteria pollutants. See Burtraw and Toman, Discussion Paper No 98-01-REV (cited in note 169).

346 See Risk Assessment and Cost/Benefit Analysis for New Regulations, Joint Hearing on Title III, HR 9 before the Subcommittee on Commerce, Trade, and Hazardous Materials and the Subcommittee on Health and Environment of the House Committee on Commerce, 104th Cong. 1st Sess 145, 146-49 (1995) (testimony of Lester B. Lave, Higgins Professor of Economics and Finance, Carnegie Mellon University) (remarking that because of limited expertise in agencies, they need to be furnished with "template analyses" that can serve as models for future analyses).

347 For a general discussion, see EPA, Global Warming: Climate, available online at 
changes in precipitation patterns, environmental quality, and human health. ${ }^{3 \cdot 3}$ Carbon dioxide has the most significant effect, contributing 82.4 percent of total U.S. GHG emissions in $1999 .{ }^{3.9}$ By far the most significant source of carbon dioxide emissions is fossil fuel combustion, which was responsible for 98 percent of U.S. carbon dioxide emissions in $1998 .^{350}$ Carbon dioxide emissions from fossil fuel consumption were responsible for "80 percent of global warming potential (GWP) weighted emissions in the 1990's.",311

The process of burning fossil fuels causes the carbon in them to be released as carbon dioxide. ${ }^{352}$ Such fuels differ significantly in the amount of carbon dioxide they release per unit of energy produced. ${ }^{353}$ Coal gives off the most carbon dioxide, with petroleum giving off about 25 percent less, and natural gas 45 percent less. ${ }^{344}$ Electric utilities, responsible for the vast majority of annual coal consumption, produced more carbon dioxide emissions in 1999 than any other sector-transportation, industrial, commercial, or residential. ${ }^{355}$ Reducing the amount of overall fuel consumed by the electricity sector and shifting coal consumption to less carbon-intensive fossil fuels would bring about significant reductions in carbon dioxide emissions. ${ }^{336}$ As the recently released Climate Action Report 2002 observes, "Federal programs promote greenhouse gas reductions through the development of cleaner, more efficient technologies for electricity generation and transmission." ${ }^{357}$ Similarly, an environmental advocate recently testified before Congress: "Electric generation is responsible for 40 percent of total U.S. $\mathrm{CO}_{2}$ emissions. We have the technology to make significant reductions in $\mathrm{CO}_{2}$ from this sector though [sic] a combination

<http://www.epa.gov/globalwarming/climate/index.html> (visited Apr 21, 2002) (discussing the implications of global warming for the earth's climate).

343 See id (reviewing the effects of rising global temperatures on the environment).

349 EPA, National Emissions: Recent Trends in U.S. Greenhouse Gas Emissions fig ES-4, available online at $<\mathrm{http} / / \mathrm{www}$.epa.gov/globalwarming/emissions/national/trends.html $>$ (visited Apr 21, 2002) (pointing out the contribution of the direct GHGs to total U.S. emissions).

350 EPA, National Emissions: Carbon Dioxide Emissions, available online at <http://www.epa.gov/globalwarming/emissions/national/co2.html> (visited Apr 21, 2002); Burtraw and Toman, Discussion Paper No 98-01-REV at *3 (cited in note 169) (noting the significance of fossil fuel combustion for GHG emissions).

351 EPA, National Emissions: Recent Trends (cited in note 349). The concept of GWP allows policymakers to compare the impact on global warming of various gases, using $\mathrm{CO}_{2}$ as a baseline.

352 EPA, National Emissions: Carbon Dioxide Emissions (cited in note 350).

353 Id.

354 Id.

355 See id.

356 See, for example, United Nations, Climate Change Information Kit: Climate Change Information Sheet 25: New Technologies and Policies 25, available online at <http:// unfccc.int/resource/iuckit/fact25.html> (visited Oct 3,2002) ("Switching from coal to natural gas can reduce [carbon dioxide] emissions by up to $40-50$ percent.").

357 EPA, Climate Action Report 200251 (May 2002), available online at <http://www.epa.gov/globalwarming/publications/car> (visited Sept 3, 2002). 
of efficiency measures on the supply and the demand side, and through increased reliance on cleaner fuels." ${ }^{338}$

Policies that expressly seek greenhouse gas reductions in the electricity sector can be expected to produce a shift away from coal consumption. But even policies that expressly target reductions in conventional pollutants and not GHGs can also lead to a decrease in carbon dioxide emissions from the electricity sector. That is because in addition to being the most carbon-intensive fossil fuel, coal is also the "dirtiest" in terms of releasing conventional pollutants into the atmosphere. At the same time, natural gas, in addition to being the least carbon-intensive fossil fuel, is also significantly cleaner-burning than coal. $^{359}$ Thus, if electricity producers were to respond to a regulatory regime requiring a reduction in criteria pollutants in part by switching from coal to natural gas consumption, they would in so doing reduce $\mathrm{CO}_{2}$ emissions. Such a process change would have the ancillary benefit of reducing GHG emissions to a significant extent.

\section{Regulation of criteria pollutants and incentives for electricity production.}

In this Part, we identify some regulatory regimes that target criteria pollutants and that can be expected to produce (or have already produced) process changes away from dirtier and toward cleanerburning fuels. In so doing, these regulatory regimes have had, or can be expected to have, ancillary benefits for GHG reductions.

a) $\mathrm{SO}_{2}$ caps. The 1990 amendments to the Clean Air Act added Title IV ("Acid Deposition Control"), ${ }^{361}$ which for the first time established a federal regulatory regime for reducing acid rain by targeting its chief precursors, $\mathrm{SO}_{2}$ and $\mathrm{NO}_{x}$. Acid deposition occurs when

358 Climate Change Technology and Policy Options, Testimony of David Hawkins, Director, Climate Center, Natural Resources Defense Council, before the Senate Committee on Commerce, Science, and Transportation (July 10, 2001), available online at <http:// commerce.senate.gov/hearings/071001Hawkins.pd6 (visited Sept 3,2002).

359 See Dallas Burtraw and Karen Palmer, Project Summary: Achieving Pollution Reductions from Electric Generation by Promoting Fuel Switching from Coal to Natural Gas (Resources for the Future), available online at <http:/www.rfforg/proj_summaries/99files/ burtraw_99fuelswitching.htm $>$ (visited Apr 21, 2002) (investigating “the desirability, cost effectiveness, feasibility, and practicability of switching fuels from coal to natural gas at major electric generating plants"). By analogy to our discussion of direct risk tradeoffs in Part II.A, we might say that $\mathrm{CO}_{2}$ reduction bears an internal relationship to the reduction in criteria pollutants.

360 Wiener cautions that although burning natural gas releases about one half the carbon dioxide that burning coal releases, the accidental leakage of methane into the air can itself have detrimental effects on the environment. Thus, there is a risk tradeoff in protecting the global environment through burning natural gas as opposed to fuel or petroleum. See Jonathan Baert Wiener, Protecting the Global Environment, in Graham and Wiener, eds, Risk versus Risk 193, 210 (cited in note 2).

36142 USC $\S \S 7651-510$ (2000). 
these precursors "are oxidized in the atmosphere and the resultant compounds fall to earth in the form of rain, snow, or hail, or as dry particles and aerosols." ${ }^{32}$ Title IV set a cap on aggregate emissions of $\mathrm{SO}_{2}$ by electric utilities and instituted an $\mathrm{SO}_{2}$ emissions trading program. Since fossil fuel consumption in the electricity sector is responsible for two-thirds of $\mathrm{SO}_{2}$ emissions, ${ }^{344}$ Title IV has had the most immediate and profound impact on that sector. ${ }^{365}$ Compliance with the $\mathrm{SO}_{2}$ caps has been achieved, in part, through process changes away from the consumption of coal and toward cleaner-burning fuels like natural gas. ${ }^{36 s}$

An ancillary benefit of that transition has been a reduction in GHG emissions. On occasion, this ancillary benefit of GHG reduction has been explicitly noted. ${ }^{357}$ Generally, however, studies of the 1990 amendments have merely shown that the $\mathrm{SO}_{2}$ caps have ushered in process changes away from coal and toward natural gas consumption without noting the implications for $\mathrm{CO}_{2}$ reductions. Consider, for example, the EPA's assessment of the impact of the $\mathrm{SO}_{2}$ caps predicted in the Regulatory Impact Analyses ("RIAs") for the revised NAAQS for particulate matter and ozone, which were the subject of the American Trucking litigation. ${ }^{363}$ In order to assess the efficacy of the

362 Bruce A. Forster, The Acid Raid Debate: Science and Special Interests in Policy Formation 12 (Iowa State 1993).

363 See Dallas Burtraw, et al, The Costs and Benefits of Reducing Acid Rain *1, Discussion Paper No 97-31-REV (Resources for the Future 1997), available online at <http://www.rfforg/ CFDOCS/disc_papers/PDF_files/9731.pdf (visited Apr 21, 2002) (presenting an analysis of the prospective costs and benefits of Title IV's Allowance Trading System for reducing $\mathrm{SO}_{2}$ and Title IV's mandated reductions in emissions of $\mathrm{NO}_{\mathrm{x}}$ ).

364 EPA, National Pollutant Emission Estimates for 1999, available online at <http://www.epa.gov/ttn/chief/trends> (visited Oct 3, 2002). Ninety-three percent of those emissions were brought about by coal consumption. Id.

365 For a general discussion, see EPA, Office of Atmospheric Programs, Clean Air Markets Division, EPA, Impacts of the Acid Rain Program on Coal Industry Employment, Report No 430R-01-002 (2001), available online at <http://www.epa.gov/airmarkt/articles/ coalemployment.pdf (visited Apr 21, 2002); Peter T. Kilborn, East's Coal Towns Wither in the Name of Cleaner Air, NY Times A1 (Feb 15, 1996) (explaining the economic impact of clean air requirements on coal-mining areas).

366 See text accompanying notes 369-71.

367 A recent study by the Energy Information Administration ("EIA") states that "strategies to control other air emissions to comply with the requirements of the Clean Air Act Amendments of 1990" are a contributing factor in $\mathrm{CO}_{2}$ reductions from year to year. Department of Energy and EPA, Carbon Dioxide Emissions from the Generation of Electric Power in the United States (2000) (joint report), available online at <http://www.eia.doe.gov/ cneaf/electricity/page/co2_report/co2report.html> (visited Apr 21, 2002). This acknowledgment of ancillary benefits came not in a study of the effects of Acid Deposition Control as such, but in a Department of Energy study that focused on $\mathrm{CO}_{2}$ emissions from the electricity sector.

368 See EPA, Innovative Strategies and Economics Group, Office of Air Quality Planning and Standards, Regulatory Impact Analyses for the Particulate Matter and Ozone National Ambient Air Quality Standards and Proposed Regional Haze Rule 5-5-5-6 (July 17, 1997), available online at <http://www.epa.gov/ttn/oarpg/naaqsfin/ria.html > (visited Apr 21, 2002) (discussing the EPA's $\mathrm{SO}_{2}$ control options). 
new NAAQS, the EPA began with a sophisticated estimate of the environmental baseline against which to study the distinctive effects of the revised standards. The discussion of the baseline imputed a wide range of transformations to "existing Title IV requirements and the more stringent $\mathrm{SO}_{2}$ cap." ${ }^{369}$ In documenting the various $\mathrm{SO}_{2}$ control options, the EPA referred to both "[r]epower[ing] existing coal-fired or oil-fired units to natural gas combined-cycle" ${ }^{310}$ and "[r]etir[ing] existing coal-fired, or oil-fired units and replac[ing] them with combined cycle natural gas units." ${ }^{371}$ Thus, in the context of establishing a meaningful baseline for the study of the impact of the NAAQS, the EPA determined that the Title IV SO${ }_{2}$ regime would have significant implications for fuel switching in the electricity sector. ${ }^{3 n}$ Other studies have similarly concluded that the $\mathrm{SO}_{2}$ caps will lead to fuel switching.

b) Ozone provisions. In the RIA for the revised ozone NAAQS, the EPA undertook a careful study of the techniques through which industry might comply with the new regulations. It concluded that, as in the case of the $\mathrm{SO}_{2}$ caps, the new standards would likely bring about various process changes in the electricity sector away from coal consumption and toward cleaner-burning fuels. For instance, the RIA included an illustrative list of controls that might be undertaken to comply with the new standards. The controls included "fuel switching," "natural gas replacement," and "repowering.",7/4 The document states:

A company or industry facing increasingly more stringent solvent emission limits, for example, is unlikely to seek ever more expensive add-on control devices. Instead they will seek substitutes such as non-volatile material inputs or process changes. Redesign of both products and processes becomes a likely operative part of this industry's or company's environmental solution. ... Other

369 Id at 5-5.

370 Id at 5-5-5-6.

371 Id. The EPA concluded that even under the cap, overall electricity production would remain constant due to a "predicted increase in combined-cycle natural gas unit capacity that is expected to offset a predicted decrease in coal steam and oil/gas steam generation capacity." Id at $11-16$.

372 An early study of techniques for meeting the Title $\mathrm{IV} \mathrm{SO}_{2}$ standards called attention to the significance of "changing the method by which electricity is produced," including "the use of oil and natural gas rather than coal." Forster, Acid Rain Debate at 100-01 (cited in note 362).

373 In their study of the ancillary benefits of $\mathrm{CO}_{2}$ reductions for conventional pollutants, Burtraw and his coauthors argue that the opportunity costs of GHG reductions have previously been overstated because studies have failed to account for the implications of the $\mathrm{SO}_{2}$ caps for fuel switching. See Burtraw, et al, Discussion Paper No 01-61 at*22-23 (cited in note 263).

374 EPA, Regulatory Impact Analyses at 5-6 (cited in note 368). These control techniques were considered to a lesser degree than "more conventional control approaches" such as " addon' control devices installed downstream from an air pollution source." Id at 5-1. 
substitutions, such as cleaner fuels, are commonplace and can be expected in the future as industries seek optimal solutions. ${ }^{37}$

The EPA, pursuant to Section 126 of the Clean Air Act, ${ }^{376}$ made similar findings in connection with its RIA for its rule calling for the reduction of $\mathrm{NO}_{\mathrm{x}}$ emissions to prevent excessive interstate spillovers. ${ }^{3 \pi}$ This RIA also details the control measures that electric utility generators are expected to undertake. The RIA concludes that "[i]ndustry will increase its use of natural gas over coal to generate power as part of its approach to compliance" with the new rule. ${ }^{373}$ The RIA predicts that as a result of the rule, the marginal costs of electricity generation would increase disproportionately for coal-burning sources. ${ }^{399}$ By contrast, "some owners of oil and gas-fired boilers would be better off because their control costs would be lower" than the industry average. ${ }^{300}$ The RIA also predicts that the rule might reduce overall demand for electricity because of price increases. ${ }^{321}$ Transitioning away from coal consumption to natural gas consumption and reducing overall consumption of fuel would both have ancillary benefits for GHG reductions. But as in the case of the ozone RIA, the EPA failed to take note of the ancillary benefits of the regulation.

\section{The ancillary benefits.}

We have seen how different regulatory regimes targeting two criteria pollutants have ancillary benefits in terms of GHG reductions. These benefits take the form of improved health and environmental conditions. The direct health benefits of reductions in GHG emissions are hard to pin down. But global warming may increase human mortality and morbidity in a number of ways. ${ }^{302}$ First, hotter temperatures may aggravate cardiovascular problems and lead to heat exhaustion

375 Id at $9-16$.

37642 USC $\$ 7426$ (2000).

377 See EPA, Office of Air Quality Planning and Standards, Office of Atmospheric Programs, EPA, Regulatory Impact Analysis for the Final Section 126 Petition Rule (Dec 1999), available online at <http://www.epa.gov/ttn/ecas/regdata/126fn0.pdf (visited Apr 21, 2002) (providing an analysis for the Section 126 rule, which addresses regional transport issues related to ozone attainment).

378 Id at 6-2.

379 As a corollary, the Regulatory Impact Analysis for Section 126 predicted a drop-off in labor in the coal industry, but an increase in labor in the natural gas sector. See id at 6-25.

380 Id at 6-21.

381 See id at 6-17 ("Overall, generators in the final Section 126 region are predicted to cut output during the ozone season by a percent or more, largely from power plants that would use control strategies with high marginal costs.").

382 Our discussion relies heavily on the EPA's website dedicated to presenting the health implications of global warming. See EPA, Impacts: Health, available online at <http:// www.epa.gov/globalwarming/impacts/health/index.html> (visited Apr 21, 2002) (explaining the relationship between human health and local climate). 
and other respiratory problems..$^{333}$ Second, warmer weather may promote greater concentrations of ground-level ozone, which in turn may aggravate certain respiratory conditions. ${ }^{34}$ Third, global warming might lead to increases in some infectious diseases, whether those caused by warm-weather insects (like malaria) or associated with algae blooms (like cholera). ${ }^{3 * 5}$ The EPA has stressed that these health risks are not inevitable corollaries to global warming. ${ }^{3 * 6}$ Nevertheless, a policy that retarded global warming by reducing $\mathrm{CO}_{2}$ emissions could be said to carry with it potential health benefits.

The environmental implications of global warming are vast and potentially profound. $^{357}$ The most immediate environmental implication of global warming is sea level rise, which, "[u]nlike most other manifestations of climate change ... is already a problem." Sea level rise in turn leads to beach erosion, coastal flooding, and the wholesale disappearance of coastal wetlands. ${ }^{399}$ This problem is especially acute in polar regions (including parts of Alaska) where warmer temperatures are expected to have the most concentrated impact. ${ }^{3 \%}$ Already a decline in sea ice in polar areas has been observed, ${ }^{391}$ making the coastline more vulnerable to erosion and altering the habitats of various marine mammals, such as polar bears. ${ }^{322}$ But sea level rise is not limited to the poles. ${ }^{393}$ Indeed, the EPA predicts that by 2050 , and possibly as early as 2025, the sea level along the Gulf and Atlantic coasts of the United States will rise by at least one foot. ${ }^{334}$ Erosion of the coastline will magnify the impact of storms, promote flooding, and increase the salinity of bays and rivers. ${ }^{395}$

\footnotetext{
383 See id.

384 See id.

385 See id.

386 See id.

387 See EPA, Global Warming: Climate (cited in note 347).

388 Stephen P. Leatherman, Social and Economic Costs of Sea Level Rise, in Bruce C. Douglas, Michael S. Kearney, and Stephen P. Leatherman, eds, Sea Level Rise: History and Consequences 181, 181 (Academic 2001).

389 See id at 183.

390 See EPA, Impacts: Climate Change and Polar Regions, available online at <http://www.epa.gov/globalwarming/impacts/polarregions/index.html> (visited Apr 21, 2002) ("Climate models indicate that global warming will be felt most acutely at high latitudes, especially in the Arctic where reduction in sea ice and snow cover are expected to lead to the greatest relative temperature increases.").

391 Id.

392 Id.

393 See, for example, Lesley Ewing, Overview of Sea Level Rise and Some Implications for Coastal California, in Rising Tides, Eroding Shores: The Legal and Policy Implications of Sea Level Rise and Coastal Erosion *8 (University of Maryland School of Law, Environmental Law Program Apr 20,2001) (on file with authors).

394 EPA, Impacts: Coastal Zones, available online at <http://www.epa.gov/globalwarming/ impacts/coastal/index.html> (visited Apr 21, 2002).

395 See id.
} 
Agricultural production will also be affected by global climate change. Although some areas will become more fertile, the benefits will probably be outweighed by the overall harms of heat and drought. ${ }^{36}$ Inland and coastal fish can also be affected by global warming. ${ }^{397}$ More generally, changes in temperature and precipitation patterns might bring about irreversible transformations in various ecosystems, from deserts ${ }^{358}$ to mountainous regions ${ }^{399}$ to forests. ${ }^{400}$ Although the nature and magnitude of the impact is unknown, there is reason to believe that global warming will have negative consequences for these and other regions.

\section{B. Ancillary Benefit Analysis and the Federal Environmental Statutes}

Showing that regulatory policies bring about ancillary benefits would be of limited utility if the relevant statutes prohibited the agencies from considering those benefits as part of their rulemaking proceedings. NAAQS under the Clean Air Act, the ancillary benefits of which we noted in our case study, ${ }^{42}$ furnish an illustration of why the statutory language is broad enough to embrace ancillary benefit analysis. Section 109(b)(1) requires that the primary NAAQS be set at a level "requisite to protect the public health."

\footnotetext{
396 See, for example, Climate Change 2001: Impacts, Adaptation, and Vulnerability: A Report of Working Group II of the Intergovernmental Panel on Climate Change *9 (2001), available online at <http://www.ipcc.ch/pub/wg2SPMfinal.pdf (visited Apr 21, 2002) (discussing the effects of climate change on crop yield).

397 See EPA, Impacts: Fisheries, available online at <http://www.epa.gov/globalwarming/ impacts/fisheries/index.html> (visited Apr 21, 2002) (explaining the effects of global warming on inland, coastal, and ocean fisheries).

398 See EPA, Impacts: Deserts, available online at <http://www.epa.gov/globalwarming/ impacts/deserts/index.html> (visited Apr 21, 2002) (discussing whether global warming will lead to the expansion of deserts).

399 See EPA, Impacts: Climate Change and Mountain Regions, available online at $<$ http://www.epa.gov/globalwarming/impacts/mountains/index.html> (visited Apr 21, 2002) (stating that scientists expect global climate change "to affect mountain and lowland ecosystems, the frequency and intensity of forest fires, the distribution of water, and the diversity of wildlife").

400 See EPA, Impact: Forests, available online at <http://www.epa.gov/globalwarming/ impacts/forests/index.html> (visited Apr 21, 2002) (warning that global warming may lead to a less diverse mix of tree species).

401 For the argument that global warming will actually enhance American economic activity, see generally Robert O. Mendelsohn, Global Warming and the American Economy: A Regional Assessment of Climate Change Impacts (Cheltenham 2001). See also John Tierney, The Big City: Warming up to the Notion of Warming, NY Times D1 (Dec 7, 2001) (reviewing Mendelsohn's findings). Mendelsohn's celebration of the positive impact of global warming on the American economy-even if one assumes that he is correct about it-overlooks the economic and environmental damage done to other countries.

402 See text accompanying notes $382-401$.

40342 USC $\$ 7409$ (b)(1) (2000).
} 
provides that secondary NAAQS be set at a level "requisite to protect the public welfare." "Welfare," in turn, is defined extremely broadly:

All language referring to effects on welfare includes, but is not limited to, effects on soils, water, crops, vegetation, manmade materials, animals, wildlife, weather, visibility, and climate, damage to and deterioration of property, and hazards to transportation, as well as effects on economic values and on personal comfort and well-being, whether caused by transformation, conversion, or combination with other pollutants. ${ }^{405}$

As we have seen, the D.C. Circuit held in American Trucking that the statutory language was broad enough to include risk tradeoffs. But the language is also broad enough to contemplate ancillary benefits. Just as it would be "bizarre" for a "statute intended to improve human health" to require that "only one half of a substance's health effects" be examined, ${ }^{407}$ so it would be equally implausible for that same statute to require the investigation of only one half of the ancillary effects of a regulation.

Sections 108 and 109 of the Clean Air Act are not unique in allowing ancillary benefit analysis. A representative survey of other statutory provisions from the Clean Air Act reveals them to be drafted in such a way as to accommodate our suggested methodology. For example, the EPA must set emissions standards for new sources "taking into account the cost of achieving such reduction and any nonair quality health and environmental impact." dards under the hazardous air pollutant provisions of the Clean Air Act are similarly defined to require attention to "non-air quality health and environmental impacts." ${ }^{409}$ Section 169 of the Clean Air Act defines the "best available control technology" emission limitation in areas that have better air quality than the NAAQS by reference to a case-by-case inquiry that takes into account "environmental, and economic impacts." ${ }^{410}$ And in requiring economic impact analyses under Section 312 of the Clean Air Act, the statute requires the EPA Administrator to "consider all of the economic, public health, and environmental benefits of efforts to comply with such standard.", Language of this sort permits-arguably even requires-the EPA to consider

40442 USC $\$ 7409$ (b)(2) (2000).

40542 USC $\$ 7602(\mathrm{~h})(2000)$.

406 See American Trucking, 175 F3d at 1052-53. See text accompanying notes 61-66.

407 American Trucking, 175 F3d at 1052 ("Legally, [the] EPA must consider positive identifiable effects of a pollutant's presence in the ambient air in formulating air quality criteria.").

$40 \$ 42$ USC $\$ 7411$ (a)(1) (2000) (emphasis added).

40942 USC $\$ 7412$ (d)(2) (2000) (emphasis added).

41042 USC $\$ 7479(3)(2000)$.

41142 USC $\$ 7612(b)(2000)$. 
ancillary benefits. And there is nothing in this language that restricts such an inquiry to negative effects.

\section{Ancillary Benefits and Causation: The Mirror Image Principle}

Critics of ancillary benefit analysis might complain that we are venturing too far afield, and that the ancillary benefits of a regulation might be too remotely connected to the regulation's primary effects. By "too remote," critics of our suggestion might mean one of two things. Ancillary benefits might be thought to be analytically or bureaucratically too remote. By "analytic remoteness," we mean to convey the idea that the ancillary effects are mediated by too many intervening steps to link them credibly to the original regulation. By "bureaucratic remoteness," we mean to suggest that the benefits might be too removed in the sense of implicating the expertise and legal jurisdiction of an agency or subagency too distant from the one tasked with implementing the regulation in the first place.

In fact, we are sympathetic to the view that the link between the two should not be excessively attenuated. What we argue for is parity in the treatment of risk tradeoffs and ancillary benefits. Just as the link might be too attenuated for certain ancillary benefits, so it might also be excessively attenuated for certain risk tradeoffs. We invoke a mirror image principle, according to which ancillary benefits should be put on the same theoretical and practical footing as risk tradeoffs.

If an agency were to ignore the ancillary effects of a regulation altogether, its understanding of the regulation and its impact on society might thereby be impoverished, but it would not be biased in a systematic way. Such a state of affairs prevailed in the regulatory state until the recent emergence of risk tradeoff analysis. It was as though the agency had decided to draw a small circle-defined by reference to a tight causal link-around the regulation's primary effects and to consider only those effects that took place within the circle.

With the emergence of risk tradeoff analysis, the agencies' attention has been drawn to the risk tradeoffs of regulation. Thus, with respect to some of the ancillary effects of regulation, the radius of the circle has been increased-reflecting a looser causal link-to include a wider range of regulatory impacts. In order to maintain parity, it is incumbent upon the agency to consider ancillary benefits as well. There is simply no causation-based argument for proceeding otherwise.

The mirror image principle, in addition to pointing out the need to interpret the statute to require uniform attention to ancillary effects, suggests answers to two potential challenges to our account. In response both to the claim that ancillary benefits are too remote, and to the analytically distinct argument that the cost of considering ancillary benefits may outweigh the benefits it (the consideration itself, 
that is) may confer, we say, in effect: If it is good enough for ancillary risks, then it is good enough for ancillary benefits.

The same mirror image principle should apply to the cost-benefit analysis of the study of ancillary benefits. It will not always be desirable to consider the ancillary effects of regulation. ${ }^{412}$ Sometimes the costs of those studies will be great and the potential benefits too slight. We recognize this problem but note that the same standards applied to determine whether it is worth undertaking risk tradeoff analysis should apply as well to ancillary benefit analysis.

\section{CONCLUSION}

The law contains many instances in which our attention to the secondary effects of a rule or regulation is drawn only selectively. This partial attention can sometimes be justified by the operative normative framework. For instance, courts have struck down statutes as overbroad in part because they have a chilling effect on future expression quite apart from their primary effect of restricting present speech. ${ }^{43}$ The chilling effect can be thought of as an instance of an ancillary harm of the regulation. Focusing exclusively on the ancillary harm (as opposed to entertaining the possibility of ancillary benefits) of a speech regulation is justified by our strong normative commitment to free speech. In this area of law, we are generally content to build into our analysis a tendency to "overstate" the harmful effects of speech regulation in order to reinforce a basic legal norm.

Similarly, in certain normative contexts, selective attention to ancillary benefits is desirable. In his recent Madison Lecture, ${ }^{414}$ Justice Breyer argued that constitutional law ought to take seriously the "liberty of the ancients" (to use Constant's formulation ${ }^{4 / 5}$ ) and not merely

412 See Sunstein, $63 \mathrm{U}$ Chi L Rev at 1553 (cited in note 3) ("[I]t is impossible to know whether to undertake health-health analysis without first doing a bit of health-health analysis, at least by making some initial judgments about the ancillary risk-a risk that, by hypothesis, the agency has not yet explored."). To this "paradox of recursive deliberation," a theoretically insoluble "optimal stopping problem," Wiener posits an institutional solution in which institutions most able efficiently to consider risk tradeoffs do so, all the while avoiding the twin pitfalls of "supersynopticism" and "blind incrementalism." 9 Risk at 75-76 (cited in note 35). See also Jay D. Wexler, Risk in the Balance, 30 Conn L Rev 225, 254 (1997) (reviewing Graham and Wiener, eds, Risk versus Risk (cited in note 2), and arguing that, in applying risk tradeoff analysis, a court should answer conservatively the question of "which risks" to focus on).

413 See, for example, Gooding $v$ Wilson, 405 US 518, 527-28 (1972) (noting the potential chilling effect of a broadly drafted statute regulating speech). See also Richard H. Fallon, Jr., Making Sense of Overbreadth, 100 Yale L J 853, 856 (1991) ("develop[ing] a framework for thinking about the shape that overbreadth doctrine ought to take and ... offer[ing] suggestions about when statutes should be held overbroad and what remedial consequences such holdings ought to have").

414 Stephen Breyer, Madison Lecture: Our Democratic Constitution, 77 NYU L Rev 245, 246 (2002).

415 See Benjamin Constant, Political Writings 309-28 (Cambridge 1988). Isaiah Berlin re- 
the "liberty of the moderns." Judges, when engaged in constitutional interpretation, ought to be sensitive to securing this "active liberty" in addition to protecting the basic rights of modern, negative liberty against majoritarian infringement. Although Justice Breyer did not formulate the matter in precisely this way, it is possible to think of enhancing positive liberty as an ancillary benefit of various actual or hypothetical legal regimes. For example, in connection with the recent Supreme Court jurisprudence on equal protection and voting rights, Justice Breyer noted that the positive liberty-enhancing properties of race-based districts supply a powerful argument for their legality. ${ }^{416}$ The reason why we do (or ought to) investigate this positive effect of gerrymandering more than potential negative ancillary effects is because of our foundational commitment to democratic decisionmaking. Thus, depending on context, we may have strong normative reasons to investigate more thoroughly either ancillary harms or ancillary benefits of different legal regimes.

Turning to our project, we can now ask: What kind of normative commitment would justify paying attention exclusively to the ancillary harms of regulation, rather than ancillary benefits? We suggest that only an ideological dedication to a minimal administrative state and a concomitant skepticism about regulation could justify that state of affairs. That set of commitments, however, is not characteristic of the post-New Deal administrative state. On the contrary, in the area of health, safety, and environmental regulation, our commitment in this age of cost-benefit analysis should be seen as favoring rationality. Overly stringent and overly lax regulation are both undesirable, and are undesirable for the same reason:They decrease social welfare.

Within the sphere of risk regulation, our normative commitment tugs not in the direction of accentuating ancillary harms or benefits, but in the direction of parity between them. In this vein, we offer ancillary benefit analysis as a means of achieving parity in regulatory policy.

In this year's State of the Union Address, President Bush expressed the view that government policies implemented in the wake of the terrorist attacks of September 11, 2001 will have important ancillary benefits. He said: "Homeland security will make America not only stronger, but, in many ways, better. Knowledge gained from bioterrorism research will improve public health. Stronger police and fire departments will mean safer neighborhoods. Stricter border enforcement will help combat illegal drugs." ${ }^{47}$ We encourage policymak-

ferred to these as positive and negative liberty respectively. See Isaiah Berlin, Four Essays on Liberty 121-22 (Oxford 1969).

416 See Breyer, 77 NYU L Rev at 264-65. (cited in note 414).

417 President George W. Bush, State of the Union Address, (Jan 29, 2002) available online at 
ers to follow the President's example and consider the ancillary benefits of health, safety, and environmental regulation. 